Linköping University Medical Dissertations No. 1617

Studies from the Swedish Institute for Disability Research No. 91

\title{
Prosodic and Phonological Ability in Children with Developmental Language Disorder and Children with Hearing Impairment
}

In the Context of Word and Nonword Repetition

\author{
Simon Sundström
}

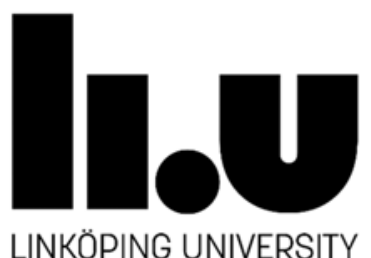

Department of Clinical and Experimental Medicine

Linköping University, Sweden

Linköping 2018 
Prosodic and Phonological Ability in Children with Developmental Language Disorder and Children with Hearing Impairment

In the Context of Word and Nonword Repetition

Edition 1:1

ISBN: 978-91-7685-321-4

ISSN: 0345-0082

ISSN: $1650-1128$

Distributed by:

Department of Clinical and Experimental Medicine

Linköping University

SE-581 83 Linköping

Sweden

(C) Simon Sundström, 2018

Department of Clinical and Experimental Medicine

Published articles have been reprinted with the permission of the copyright holder.

Printed in Sweden by LiU-Tryck, Linköping, 2018 


\section{CONTENTS}

ABSTRACT

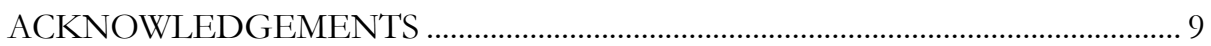

LIST OF PAPERS ……………………………………………………………….... 11

ABBREVIATIONS ........................................................................................... 12

INTRODUCTION …………………………………………………………….... 13

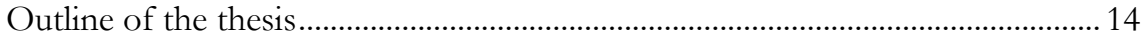

Children with developmental language disorder .................................................... 16

Developmental language disorder ......................................................... 16

Classification and severity .................................................................... 17

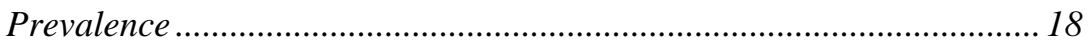

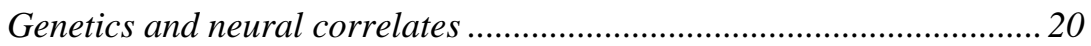

Theoretical accounts of language disorder............................................. 20

Children with hearing impairment......................................................................... 22

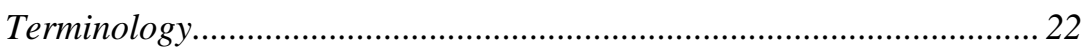

Classification of hearing impairment..................................................... 22

Prevalence and etiology ………………………………......................... 23

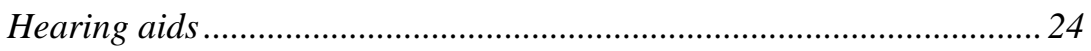

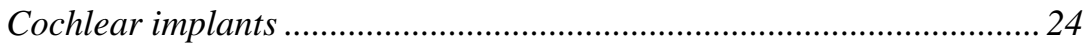

Development of speech, language and cognition.................................... 26

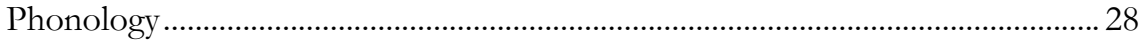

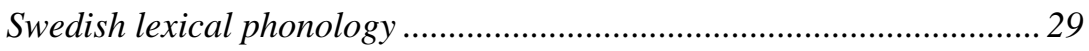

Typical prosodic and phonological development......................................33

Phonological development in children with developmental language

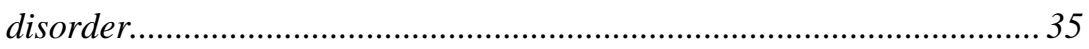

Phonological development in children with hearing impairment............ 37

The relation between prosody and language ability ................................. 43

Immediate repetition............................................................................................. 45

Word and nonword repetition ................................................................. 45 
Theoretical frameworks for word and nonword repetition .................... 47

Repetition and language ability ........................................................ 50

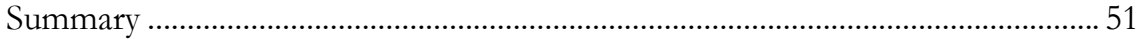

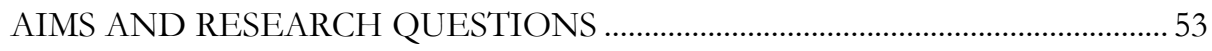

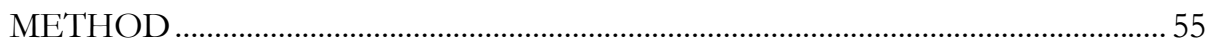

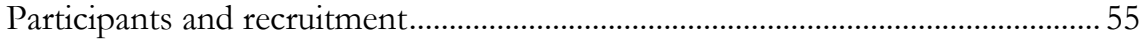

Children with developmental language disorder .................................55

Children with hearing impairment .................................................... 55

Children with typical language development........................................56

Ethical considerations ...................................................................... 57

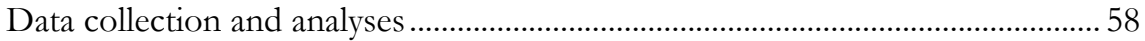

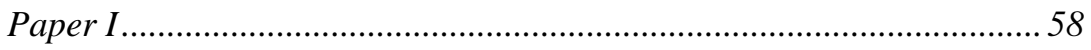

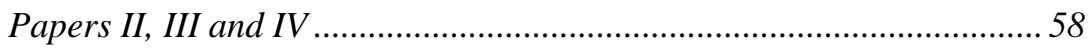

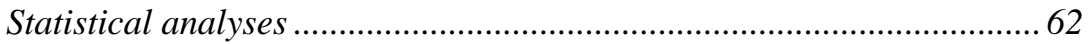

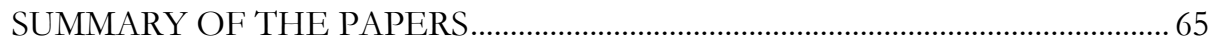

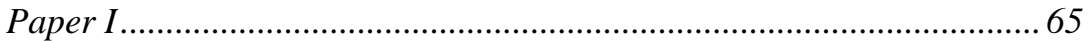

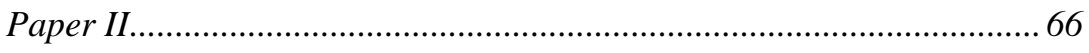

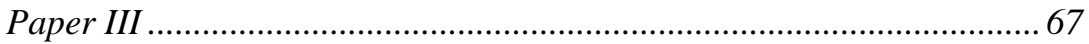

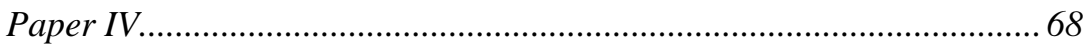

DISCUSSION

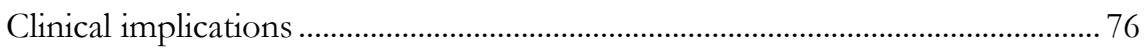

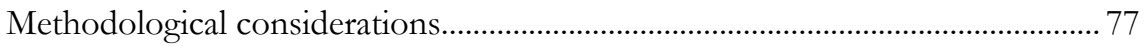

Participants and recruitment............................................................ 78

Limitations of the WR and NWR task ................................................. 79

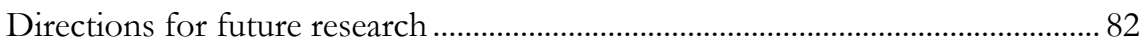

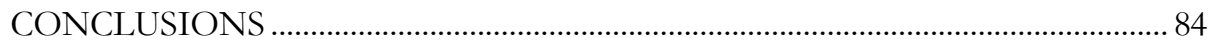

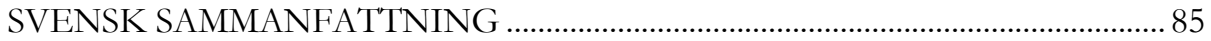

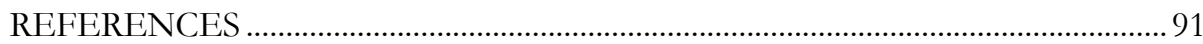




\section{ABSTRACT}

Many children with developmental language disorder (DLD) exhibit difficulties with phonology, i.e. the sounds of language. Children with any degree of hearing impairment $(\mathrm{HI})$ are at an increased risk of problems with spoken language, including phonology. The cause of these difficulties is unknown in children with DLD, and is often assumed to result from reduced hearing acuity in children with HI. Variability in terms of language outcomes is large in both groups, and determining if a child's language ability is within normal limits or not is problematic. A task that has proven useful in differentiating typical from atypical language development is nonword repetition, in which the child listens to a word form without meaning and repeats it back immediately. Performance in nonword repetition tasks is a potential indicator of language ability in both children with DLD and children with HI. However, it has not been established exactly what the task measures.

In the present thesis, the ability to repeat prosodic and segmental features of real words and nonwords was investigated in Swedish-speaking four- to six-year-old children with DLD and HI, as well as in children with normal hearing and typical language development (TLD) (papers I, II and III). Further, relations of word and nonword repetition ability to language and hearing were explored (papers II and III), along with comparisons of phonological and grammatical production between the groups (paper IV).

The findings indicated that the prosodic features stress and tonal word accent affect repetition performance in children with DLD, HI, and TLD. In general, the children with DLD and HI achieved lower results than the children with TLD on repetition of segments (consonants and vowels) and prosodic features, but tonal word accent was repeated with relatively high accuracy. Tonal word accent 1 was more accurately repeated than tonal word accent 2 by the DLD and HI children. The children with TLD repeated tonal word accent with few errors, but segments in nonwords with tonal word accent 2 were easier to repeat than segments in nonwords with tonal word accent 1 .

The results further revealed that the ability of children with DLD to repeat stress in real words is related to expressive grammar, but repetition of prosodic features does not reflect general language knowledge. In contrast, repetition of both segmental and prosodic nonword features may be indicative of receptive vocabulary, phonological production during naming of familiar words, and expressive grammar in children 
with HI. Repetition performance might be related to the degree of $\mathrm{HI}$ before cochlear implantation or fitting of hearing aids.

Children with DLD and children with HI demonstrate similar strengths and weaknesses in phonological and grammatical production, despite the fact that they develop language under different conditions_-with and without normal hearing. Tonal word accent use and syntax are relatively unimpaired in DLD and HI children.

This thesis highlights prosodic and phonological strengths and weaknesses in children who have, or are at risk of, deficits in language and communication abilities. It also supports word and nonword repetition as potential predictors of some aspects of language ability in children with DLD and HI. Further, it emphasizes the importance of taking prosody into account when constructing, or interpreting results from, repetition tasks. Future research aiming to investigate the relationship between prosody in repetition and language, cognition and hearing, should use longitudinal study designs, and include younger children. Studies comparing prosodic and phonological ability in children with DLD and children with HI should employ both quantitative and qualitative analyses. 


\section{ACKNOWLEDGEMENTS}

First and foremost, I would like to thank Christina Samuelsson, my main supervisor. Thank you for supporting me and showing unwavering interest in my work throughout this project, and for encouraging me to do research in the first place. Always keeping standards high, you have been generous in sharing your knowledge and creativity, and in helping me correct the mistakes you have given me the freedom to make.

Next, I thank my co-supervisor, Björn Lyxell. It has been a true privilege working with you, and my only regret is that I did not bother you with more questions. With calm enthusiasm, you have inspired me to look at the bigger picture, and to never lose touch with the human behind the data.

My many thanks to Ulrika Löfkvist. You have been my guide to everyday reality for children with hearing impairment and the speech-language pathologists working with them. Your theoretical and practical resourcefulness has really been invaluable to me, and to this project.

$\mathrm{My} \mathrm{PhD}$ work has been completely reliant on collaboration with hospital clinics and preschools. I would like to thank everyone that have taken their time to help me, with special mention of Birgitta Rosén, Eva Karltorp, Inger Uhlén, Elisabet Östlund, Claes Möller, Elina Mäki-Torkko, and Anette Skännestig.

My sincere gratitude to Hanna Walsö, Vanessa Westerlind and Niklas Rönnberg for your unselfish contribution to the weird work entailed in making a useful nonword repetition task. Thanks also to my friend Dan Brehmer, who took on the role as programming consultant without hesitation.

Many insightful minds, known and unknown, have helped shape my work. Numerous people will inevitably be left out here, but I am particularly grateful for the comments and critique I received from Nicole Müller, Martin Ball, Olof Sandgren, and Paul Fletcher in the earlier stages of this endeavor.

Thanks to my past and present colleagues at the Division of speech-language pathology, audiology and otorhinolaryngology, and to fellow members of the Linnaeus Centre HEAD graduate school.

I have had the benefit of being part of a FAS-sponsored network of researchers and clinicians working with individuals with hearing impairment within a range of 
disciplines. Our meetings have always been socially enjoyable, and your different perspectives on the complexities of hearing and hearing impairments have been very enriching.

Statistics is a cruel mistress. Thanks to Örjan Dahlström and Bo Sahl for alleviating the pain.

Thanks to fellow PhD student (now PhD) Victoria Stenbäck for your company and advice. It's been a blast.

It is hard to express how thankful I am for the love and support that has come from my parents Lisa and Anders, and my parents-in-law Gunilla and Tomas. But know that I am! I would not have made it without you.

To my wonderful wife Karin, and daughter Iris, who patiently and less patiently have been there for me, always with love: You are the best!

Finally, thank you to all children and caregivers who participated in my studies. Meeting you has been the most memorable part of this project, which was possible only with your help. 


\section{LIST OF PAPERS}

I. Sundström, S., Samuelsson, C., \& Lyxell, B. (2014). Repetition of words and non-words in typically developing children: The role of prosody.

First Language, 34(5), 428-449.

II. Sundström, S., Lyxell, B., \& Samuelsson, C. (submitted). Prosodic aspects of repetition in Swedish-speaking children with developmental language disorder.

III. Sundström, S., Löfkvist, U., Lyxell, B., \& Samuelsson, C. (in press). Prosodic and segmental aspects of nonword repetition in 4- to 6-year old children who are deaf and hard of hearing compared to controls with normal hearing.

Clinical Linguistics \& Phonetics.

IV. Sundström, S., Löfkvist, U., Lyxell, B., \& Samuelsson, C. (submitted). Phonological and grammatical production in children with developmental language disorder and children with hearing impairment 


\section{ABBREVIATIONS}

ASHA American Speech-Language-Hearing Association

BEHL Better Ear Hearing Level

CI Cochlear Implant/Cochlear Implants

dB Decibel

DHH Deaf and Hard of Hearing

DLD Developmental Language Disorder

DSM-5 Diagnostic and Statistical Manual of Mental Disorders, Fifth edition

HA Hearing Aid/Hearing Aids

HI Hearing Impairment

HL Hearing Loss

ICD International Classification of Diseases and Related Health Problems

ICF International Classification of Functioning, Disability and Health

LI Language Impairment

$\mathrm{NH} \quad$ Normal Hearing

NWR Nonword Repetition

PCC Percentage of Consonants Correct

PPC Percentage of Phonemes Correct

PTA Pure Tone Average

PVC Percentage of Vowels Correct

SLI Specific Language Impairment

SLP Speech-Language Pathologist/Pathology

TLD Typical Language Development

WHO World Health Organization

WR Word Repetition 


\section{INTRODUCTION}

In spoken language, we communicate through speech. Most things we find interesting, beautiful, or indeed necessary for survival, can be formulated in words. By means of articulatory gestures, the words are given the shape of sound — sound that can then be heard and interpreted by others. An important property of human speech and language is the ability to pattern a finite number of meaningless speech sounds together into a theoretically infinite number of words that have meaning. The sounds we have at our disposal, and the rules for how to combine them in meaningful ways, are studied within the linguistic field of phonology. In the present thesis, phonology is described at two levels. At the segmental level, there are the speech sounds, commonly divided into vowels and consonants. At the prosodic (or suprasegmental) level, the linguistic use of rhythmical and intonational variations are concerned.

Acquiring speech and language is not an easy task. Although often described as effortless, it takes a child years of daily practice in interaction with others to learn their mother tongue. This is true for children who appear to have no particular disadvantages, i.e. they exhibit typical language learning ability, and they are given the opportunity to learn. For children who are at some disadvantage, learning a language is even more effortful. In this thesis, two such groups of children are studied: children who have an unexplained language disorder (developmental language disorder; DLD), and children who have a hearing impairment (HI). These groups develop language under different conditions, but have in common challenges acquiring language, including phonology, compared to typically developing children.

The obvious challenge to spoken language acquisition in children with $\mathrm{HI}$ is of course that they have reduced hearing ability, which in extension is the major explanation for speech and language deficits in this group. With the right hearing assistive technology and audiological intervention, the majority of children with HI can develop spoken language. Many can achieve age-adequate language ability, but there is an increased risk of language problems, especially concerning phonology. Further, it can be assumed that a proportion of children with HI would demonstrate deviant language development even if they did not have a HI. Subsequently, the explanation for their language deficits is different, and warrant partly different intervention. Identification of such children is challenging, since it may be difficult to determine whether problems occur as a result of the $\mathrm{HI}$, or if they stem from an independent language disorder. Comparisons of language ability in children with $\mathrm{HI}$ and children with DLD have the potential to yield knowledge that throw light on this issue. 
It is well attested that there is large variation in the rate at which children develop speech and language. A challenge for researchers and clinicians in the field of child language is how to determine which children deviate from what could be labelled 'typical development', and how to identify those children who are in need of intervention. One way of doing this is by using so called marker tasks, which are tasks that have proved particularly difficult for children who have language deficits, and that could predict language development. One such task that has been used extensively is nonword repetition. In this task, a child is asked to imitate could-be words, i.e. patterns of speech sounds that are allowed according to the phonology of a language, but that lack meaning. Previous research has demonstrated impaired nonword repetition ability in both children with DLD and children with HI. For this reason, phonological ability is investigated partly in the context of word and nonword repetition tasks in the present thesis. Special focus is on how word level prosodic features of word and nonwords are repeated by Swedish-speaking children with DLD, HI, and typical language development (TLD).

\section{Outline of the thesis}

The first part of the thesis is a theoretical introduction, including a description of the clinical groups represented (children with DLD and children with $\mathrm{HI}$ ), and a review of the main research fields of interest (phonology, word and nonword repetition). This is followed by the general aims and research questions, and an account of the method, with emphasis on the test materials used in the different studies. Thereafter, the main findings of each paper (I-IV) are summarized. The last part consists of a general discussion of the findings in order to answer the general research questions, as well as a discussion of theoretical and clinical implications, limitations, and directions for future research. The four papers are included in their entirety at the end, and an overview can be found below in table 1 . 
Table 1. Overview of the individual papers of the thesis.

\begin{tabular}{|c|c|c|c|c|}
\hline Paper & Aim & Method & Result & Conclusion \\
\hline I & $\begin{array}{l}\text { To examine the ability of } \\
\text { children with TLD to repeat } \\
\text { words and nonwords with } \\
\text { special focus on how tonal } \\
\text { word accent and word } \\
\text { length affect segment pro- } \\
\text { duction accuracy. }\end{array}$ & $\begin{array}{l}44 \text { monolingual Swedish- } \\
\text { speaking children aged } 4-6 \\
\text { years, divided into two age } \\
\text { groups, performed a WR } \\
\text { and NWR task. }\end{array}$ & $\begin{array}{l}\text { The older children outper- } \\
\text { formed the younger. Words } \\
\text { were easier than nonwords. } \\
\text { The two tonal word accents } \\
\text { provided different conditions } \\
\text { for segment repetition. }\end{array}$ & $\begin{array}{l}\text { The ability to repeat seg- } \\
\text { ments and prosodic fea- } \\
\text { tures improves between } \\
\text { the ages of } 4 \text { and } 6 \text {. Pros- } \\
\text { ody should be considered } \\
\text { in construction and use } \\
\text { of immediate repetition } \\
\text { tasks. }\end{array}$ \\
\hline II & $\begin{array}{l}\text { To examine repetition of } \\
\text { stress and tonal word ac- } \\
\text { cents in words and non- } \\
\text { words in Swedish-speaking } \\
\text { children with DLD, and to } \\
\text { investigate the relation of } \\
\text { prosodic repetition to } \\
\text { measures of language ability. }\end{array}$ & $\begin{array}{l}30 \text { monolingual Swedish- } \\
\text { speaking 4- to 6-year-olds } \\
\text { with DLD, and } 29 \text { age- } \\
\text { matched controls per- } \\
\text { formed a WR and NWR } \\
\text { task, and tests of phonolog- } \\
\text { ical production, expressive } \\
\text { grammar, and receptive vo- } \\
\text { cabulary. Group differences } \\
\text { for the repetition of pro- } \\
\text { sodic features, and correla- } \\
\text { tions between repetition } \\
\text { and language measures were } \\
\text { explored. }\end{array}$ & $\begin{array}{l}\text { Children with DLD per- } \\
\text { formed below controls on } \\
\text { repetition of prosodic features } \\
\text { of words and nonwords. Rep- } \\
\text { etition of stress and tonal } \\
\text { word accent was not corre- } \\
\text { lated with phonological pro- } \\
\text { duction or receptive vocabu- } \\
\text { lary, but a significant correla- } \\
\text { tion was found between stress } \\
\text { repetition in words and ex- } \\
\text { pressive grammar. }\end{array}$ & $\begin{array}{l}\text { Repetition of stress and } \\
\text { tonal word accents is } \\
\text { challenging for children } \\
\text { with DLD. Repetition of } \\
\text { prosodic features may } \\
\text { not be a good indicator } \\
\text { of general language abil- } \\
\text { ity, but repetition of } \\
\text { stress in words could pre- } \\
\text { dict expressive grammati- } \\
\text { cal ability. }\end{array}$ \\
\hline III & $\begin{array}{l}\text { To examine segmental and } \\
\text { prosodic aspects of immedi- } \\
\text { ate repetition of nonwords } \\
\text { in children with HI, and to } \\
\text { relate NWR performance to } \\
\text { measures of language ability, } \\
\text { and background variables. }\end{array}$ & $\begin{array}{l}\text { 14 Swedish-speaking chil- } \\
\text { dren with mild-profound } \\
\text { sensorineural HI aged } 4-6 \\
\text { years and } 29 \text { age-matched } \\
\text { controls with TLD and nor- } \\
\text { mal hearing participated. A } \\
\text { NWR task, as well as tests } \\
\text { of phonological production, } \\
\text { grammatical production, } \\
\text { and receptive vocabulary } \\
\text { were administered. }\end{array}$ & $\begin{array}{l}\text { The children with HI per- } \\
\text { formed below the children } \\
\text { with TLD on the repetition of } \\
\text { segments, stress patterns, and } \\
\text { tonal word accents. All as- } \\
\text { pects of NWR performance } \\
\text { was also related to language } \\
\text { ability, and to hearing level, in } \\
\text { the children with HI. }\end{array}$ & $\begin{array}{l}\text { Both segmental and pro- } \\
\text { sodic aspects of NWR } \\
\text { are problematic for Swe- } \\
\text { dish-speaking children } \\
\text { with HI. NWR has po- } \\
\text { tential as a clinically use- } \\
\text { ful tool for identification } \\
\text { of children who are in } \\
\text { need of specific speech } \\
\text { and language interven- } \\
\text { tion. }\end{array}$ \\
\hline IV & $\begin{array}{l}\text { To explore similarities and } \\
\text { differences between children } \\
\text { with DLD, children with HI, } \\
\text { and children with TLD, on } \\
\text { phonological, including pro- } \\
\text { sodic, and grammatical pro- } \\
\text { duction. }\end{array}$ & $\begin{array}{l}30 \text { children with DLD, } 14 \\
\text { children with HI, and } 29 \\
\text { children with TLD and nor- } \\
\text { mal hearing aged } 4-6 \text { years } \\
\text { performed a WR and NWR } \\
\text { task, and tests of phonolog- } \\
\text { ical and grammatical pro- } \\
\text { duction. }\end{array}$ & $\begin{array}{l}\text { Phonological production in } \\
\text { WR and NWR and picture } \\
\text { naming, and grammatical pro- } \\
\text { duction, were generally lower } \\
\text { for children with DLD and } \\
\text { HI compared to controls. } \\
\text { There were few differences } \\
\text { between the children with HI } \\
\text { and DLD, but predicative } \\
\text { agreement was more challeng- } \\
\text { ing for the children with HI. }\end{array}$ & $\begin{array}{l}\text { On a group level, chil- } \\
\text { dren with DLD and HI } \\
\text { have difficulties with } \\
\text { phonological and gram- } \\
\text { matical production com- } \\
\text { pared to children with } \\
\text { TLD. Production of to- } \\
\text { nal word accents emerged } \\
\text { as a relative strength, as } \\
\text { did syntax. }\end{array}$ \\
\hline
\end{tabular}

Notes: TLD = typical language development; DLD = developmental language disorder; $\mathrm{HI}=$ hearing impairment; WR = word repetition; NWR = nonword repetition. 


\section{Children with developmental language disorder}

The present thesis included children with DLD whose main language problems pertained to the domains of phonology and grammar. However, the children who can be included under the DLD definition may exhibit a range of language symptoms in different combinations. The term DLD has been surrounded by controversy, and there are other labels that may be used more or less interchangeably for the same children. The children with DLD in this thesis might also be described as having e.g. language impairment (LI), specific language impairment (SLI), or primary language impairment.

\section{Developmental language disorder}

Developmental language disorder (DLD) is used for enduring language disorders that are not associated with a known biomedical etiology. DLD may also be used when neurobiological or environmental risk factors are present, and may co-occur with other conditions, e.g. ADHD. There is no requirement for children with DLD to exhibit typical nonverbal ability (Bishop, Snowling, Thompson, Greenhalgh, \& CATALISE-2, 2017). Although unexplained language deficits in children are common, there has been a lack of agreement about classification and terminology, both between and within disciplines (Bishop et al., 2016; Reilly, Bishop, \& Tomblin, 2014). The endorsement of the term DLD, as defined above, follows from a consensus project, CATALISE (Criteria and Terminology Applied to Language Impairments: Synthesising the Evidence), which involved researchers and clinicians within the fields of speech-language pathology, psychology, audiology, education, and medicine, as well as representatives for non-profit charity organizations (Bishop et al., 2016; Bishop et al., 2017). DLD is also consistent with the terminology used in the upcoming version of the International Statistical Classification of Diseases and Related Health Problems (ICD-11) (World Health Organization, 2018b).

It remains to be seen if DLD will take hold as the main term to describe children who have persistent language deficits in the absence of a known cause. In fact, a range of other labels have been used for roughly the same condition, such as language delay, primary language impairment, language disorder, specific language impairment, language impairment, developmental dysphasia, or language learning impairment. Of these, specific language impairment (SLI) has been the most common term used to describe children who have persistent language deficits in the absence of a known cause, at least in the English research literature (Bishop, 2014). SLI is characterized by an inability of a child to acquire language as expected, despite typical development of perceptual and cognitive skills, and sufficient opportunities to use language in communication. A diagnosis of SLI is thus made based on exclusionary criteria, i.e. when there is no known etiology, 
no psychiatric or neurological disorders, hearing impairment, or intellectual disability (Schwartz, 2009).

Definition by exclusion is also used in the International Statistical Classification of Diseases and Related Health Problems 10 ${ }^{\text {th }}$ Revision (ICD-10) (World Health Organization, 2010), which is the classification employed in Swedish speech-language pathology (SLP) practice. In ICD-10, specific developmental disorders of speech and language are described as disorders in which speech and language acquisition is disturbed from early on in development. These disorders cannot be directly attributed to neurological abnormalities, sensory or motor impairments, mental retardation, or environmental factors. According to the ICD-10 diagnostic criteria for research (World Health Organization, 1993), a diagnosis of language disorder is appropriate when language ability, based on standardized testing, is more than 2 SD below the mean for the child's age. Further, there is a requirement for discrepancy between verbal and nonverbal ability in the same child; language ability should be at least 1 SD below nonverbal ability, as assessed with standardized tests.

However, the use of exclusionary criteria, cut-off limits in relation to normative means, and requirements for discrepancy between verbal and nonverbal ability, are problematic. In many cases, children with language difficulties have other problems as well. Conditions and symptoms may overlap or change over time, making exclusionary criteria less useful and reflective of reality (Dyck, Piek, \& Patrick, 2011). Cutoff scores based on deviations from a normative mean are arbitrary, and may exclude many children that would benefit from intervention. Further, there is little evidence that cut-offs are useful in dividing children into qualitatively different groups as 'disordered' vs. 'typical'. Instead, children with language disorder likely represent the lower end of the normal variation, i.e. they are quantitatively different (Dollaghan, 2011). In regard to the criteria for low language ability in relation to nonverbal ability, many children with low nonverbal ability may have age adequate language ability, and vice versa, suggesting that nonverbal ability is a poor explanation for language problems (Rice, 2016; Spaulding, Plante, \& Farinella, 2006).

\section{Classification and severity}

Children with DLD is a heterogeneous group, and language symptoms may vary considerably, both between children and in the same child over time (Conti-Ramsden \& Adams, 1995). There is no general agreement on how to classify DLD, e.g. into subcategories, or how to rate the degree of severity. A broad categorization into subgroups can be made according to whether language symptoms are mainly expressive or both expressive and receptive. More specific subgroups have been proposed where grouping is based on what components of language are affected, such as grammar, 
lexico-semantics, pragmatics, and on whether one or several language domains are problematic (Conti-Ramsden, Crutchley, \& Botting, 1997; Schwartz, 2009). In terms of severity, deficits in language comprehension are generally regarded as more severe than difficulties that are mainly expressive. Further, the degree of severity is higher when many language components are affected, especially when they have significant consequences for communication and interaction, with poor prognosis (Bishop, 1997).

\section{Prevalence}

The prevalence of DLD in children has been estimated to around 7\% (Tomblin et al., 1997). Prevalence figures reported in Swedish studies indicate that about $10 \%$ of $2.5-$ year-olds and as much as $14 \%$ of 4 -year-olds may have some degree of DLD (Miniscalco Mattsson, Mårild, \& Pehrsson, 2001; Westerlund, 1994). A common finding is that boys tend to be overrepresented among children with DLD (Tomblin et al., 1997; Westerlund, 1994). Although the prevalence of DLD is around 7\%, not all children are detected. A study conducted in England showed that only 3\% of children were identified as having some speech, language and communication needs at age 7 (Meschi, Vignoles, \& Lindsay, 2010), which is about one third of the estimated prevalence in the population (Norbury et al., 2016; Tomblin et al., 1997).

Prevalence estimates are dependent on the diagnostic criteria used. Norbury et al. (2016) could show that different established cut-off criteria for language and nonverbal ability gave estimated population prevalence numbers between $1 \%$ and $8 \%$ (see table 2). Most notably, the criteria found in ICD-10, which is the classification currently used in Swedish speech and language pathology (SLP) practice, yielded an estimate of just over $1 \%$. Strict adherence to ICD-10 would evidently exclude many children in need of SLP services (Norbury et al., 2016). Further, as pointed out by Spaulding et al. (2006), a substantial number of children with language disorders actually perform within normal limits on many standardized language tests, making cutoffs based on standard deviations unreliable for identification. 
Table 2. Prevalence of language disorder (Norbury et al., 2016).

\begin{tabular}{llc}
\hline Classification & \multicolumn{1}{c}{ Criteria } & $\begin{array}{c}\text { Population prevalence esti- } \\
\text { mates }(\%) \text { and 95\% CI }\end{array}$ \\
\hline DSM-5 & $\begin{array}{l}\text { Language below }-1.5 S D \text { of normative mean on } 2 / 5 \\
\text { composite scores, NVIQ }>70\end{array}$ & $7.6[5.3,10.7]$ \\
Tomblin et al. & $\begin{array}{l}\text { Language below }-1.25 S D \text { of normative mean on } \\
(1997)\end{array}$ & $\begin{array}{l}\text { 2/5 composite scores, NVIQ }>85 \\
\text { ICD-10 }\end{array}$ \\
& $\begin{array}{l}\text { Language below }-2 S D \text { of normative mean on } 2 / 5 \\
\text { composite scores, NVIQ }>85\end{array}$ & $1.1[0.4,11.0]$ \\
\hline
\end{tabular}

Contrary to the widely used criterion that there should be a mismatch between language and nonverbal ability, the outcomes of the CATALISE consensus study suggest that language disorders should be identified as such regardless of whether there is a discrepancy between language ability and nonverbal ability (Bishop et al., 2016). Consequently, children with low nonverbal cognitive ability, but who do not meet the criteria for intellectual disability, may be included under the DLD definition (Bishop et al., 2017). If children whose nonverbal ability score is above 70 are included in the DLD group, prevalence of DLD in the population has been estimated at $11 \%$. Further, there is evidence to suggest that children with DLD who have nonverbal ability scores that are low, but still above 70 , do not have lower language ability compared to children with DLD who have average nonverbal ability, which calls into question the discrepancy criterion (Norbury et al., 2016).

The importance of speech, language and communications skills in modern society has led some researchers to suggest that access to speech, language and communication - including SLP_-services should be regarded as a matter of public health (Law, Reilly, \& Snow, 2013). DLD often persists into adolescence and adulthood. Compared to individuals with typical language development, persons with a history of DLD more often have difficulties with spoken language and literacy skills (Stothard, Snowling, Bishop, Chipchase, \& Kaplan, 1998). On a group level, they also achieve poorer education and employment outcomes, although heterogeneity is large, and many young adults with DLD are able to secure employment (Conti-Ramsden, Durkin, Toseeb, Botting, \& Pickles, 2018). Further, DLD increases the risk of emotional and behavioral problems (Yew \& O'Kearney, 2013). 


\section{Genetics and neural correlates}

Disorders of language and literacy, such as DLD, have proved to be highly heritable (Barry, Yasin, \& Bishop, 2007; Bishop, North, \& Donlan, 1996). Several genes are associated with disordered language (Newbury \& Monaco, 2010), but the genetic architecture underpinning is complex, and no gene exclusive for DLD has been found (Graham \& Fisher, 2013). Also, although genetic and neurobiological risk factors are undoubtedly involved in DLD, there is complex interaction with environmental factors (Oliver, Dale, \& Plomin, 2004), such as socio-economic status (SES), approximated by parental education or income (Reilly et al., 2010). Different abilities may be impaired in DLD, each of which may have different environmental and genetic causes (Bishop, 2006).

Language function is regulated by brain activity, and it would appear counterintuitive to assume that there is no neural correlates of DLD. However, technological limitations may have made deviances unobservable in early studies. Advancements in brain imaging techniques have enabled studies that show atypical brain function and structure in children with DLD; compared to children with typical development, differences in structural volume and neural activation in regions known to be involved in language function have been observed (Mayes, Reilly, \& Morgan, 2015). DLD has also been proposed to stem from failure to establish cerebral lateralization (Bishop, 2013), but recent studies have failed to establish such a connection (Wilson \& Bishop, 2018). While most studies have focused on cortical areas, there are also results that point toward the implication of subcortical structures (Krishnan, Watkins, \& Bishop, 2016). It is worthy of note that studies generally have included rather small samples, and that varying methodology between studies make definite conclusions hard to make (Mayes et al., 2015).

\section{Theoretical accounts of language disorder}

Some areas of language acquisition and use seem to pose more difficulty than others in DLD, a fact that has led researchers to investigate potential core deficits that may underlie the disorder. A number of theoretical accounts of DLD has emerged, stemming from two distinct approaches to the study of child language disorder. The linguistic approach, which is largely grounded in the Chomskyan tradition, assumes that language impairment results from domain-specific linguistic knowledge deficits (Rice \& Wexler, 1996; van der Lely, 2005), while the processing approach views language impairment as a consequence of deficits in the processing of linguistic information (Gathercole \& Baddeley, 1990; Leonard, McGregor, \& Allen, 1992; Tallal \& Piercy, 1973a, 1973b). 
Within the language knowledge approach, children with DLD have been proposed to have problems with the acquisition of grammar. One such is the extended optional infinitive account, which states that children with DLD have difficulties with grammatical morphemes that express tense and agreement, such as English past tense -ed, or third person singular -s. Instead they tend to use infinite forms for a longer time than can be expected by children with typical language development (Rice, Wexler, \& Cleave, 1995). According to the computational grammatical complexity account (van der Lely, 2005) children with DLD have impaired representations and computations that underlie complex phonological, morphological or syntactic structure. The language domain that is most affected varies between subgroups of children with DLD, and the core deficit may thus not be the same in all children.

Processing-based explanations for the language deficits in DLD focus on abilities that are involved in, but not exclusive to, language use. Tallal and Piercy (Tallal \& Piercy, 1973b, 1974) found that children with DLD have problems with auditory perception, especially regarding information that is short in duration or changed rapidly, e.g. stop consonants or formant transitions, which would in turn affect language acquisition more generally (Tallal et al., 1996). This claim has, however, been surrounded by controversy (Schwartz, 2009). Another influential proposal relating to perceptual difficulties is the surface account (Leonard et al., 1992), which ascribes morpho-syntactical deficits to an impaired ability to perceive and use grammatical elements with low perceptual salience and short duration relative to surrounding element. For example, the surface account predicts that children with DLD will have problems with grammatical markers that comprise unstressed syllables.

Another strand of research puts limitations in working memory at the center of language disorder, especially phonological working memory (Baddeley, 2012). Particular interest has been shown in the phonological loop, which enables encoding, shortterm storage, and rehearsal of phonological information (Baddeley, 2003; Gathercole \& Baddeley, 1990). Reduced working memory capacity may prevent children from forming mental representations of sound sequences, and remember them long enough for identification and long-term storage (Baddeley, Gathercole, \& Papagno, 1998).

Some language deficits in DLD have also been suggested to originate from problems with procedural learning, caused by a dysfunction in neural systems involved in general acquisition and use of cognitive and motor skills. The so called procedural deficit hypothesis predicts that children who have such dysfunction will have problems with the rule-governed aspects of language, such as grammar (Ullman \& Pierpont, 2005). 


\section{Children with hearing impairment}

In the present thesis, children with different degrees of bilateral sensorineural HI participated. All children used hearing assistive technology in the form of either cochlear implants, conventional acoustic hearing aids, or a combination of these.

\section{Terminology}

Reduced hearing ability in individuals can be described in different ways. The term deaf, which is probably the most widely known and used by laymen, is used for persons with little to no hearing. Hard of hearing is instead used for persons who have partial ability to hear. In the English literature, Deaf (with a capitalized d) refers to a community of people whose language and culture are influenced by the experience of being deaf or hard of hearing, and may include individuals who are deaf, hard-of-hearing, or hearing. Hearing loss may refer to any degree of reduced hearing ability, either permanent or not. Hearing impairment is also used to describe persons with any degree of reduced hearing, and the terms hearing loss and hearing impairment are often used interchangeably. Within the framework of the International Classification of Functioning, Disability and Health (ICF) (World Health Organization, 2001), impairments are defined as "problems in body function or structure such as a significant deviation or loss" (World Health Organization, 2002, p. 10). An argument against the use of hearing impairment is the potential negative connotations of impairment, especially for persons of the Deaf community who may not regard limited hearing as impairing (Smith, Bale Jr, \& White, 2005). Throughout the present thesis, hearing impairment is used for any degree of reduced hearing ability, and is intended as a neutral term. In paper III, deaf and hard of hearing is used for the same group of children who elsewhere in this thesis are referred to as having hearing impairment.

\section{Classification of hearing impairment}

$\mathrm{HI}$ is a complex condition, and may be classified in various ways. Commonly, descriptions are made of the type of $\mathrm{HI}$, time of onset, and degree of the impairment, as well as the range of frequencies that are affected.

Type of HI can be categorized as conductive, sensorineural, or mixed. Conductive HI encompasses conditions where the conveying of sound vibrations through the outer or middle ear is hampered due to disease or deformity. Sensorineural HI implicates a dysfunction of the inner ear or the cochlear nerve, which either impedes the conversion of mechanical energy to nerve impulses in the cochlea, or the propagation of the nerve impulses through the eighth cranial nerve and central auditory pathways, up to the cerebral auditory cortex. Mixed HI denotes a combination of 
conductive and sensorineural HI (Stephens, 2001). The most common variety is sensorineural HI resulting from cochlear dysfunction.

Classification may also be made according to the time of onset; congenital $\mathrm{HI}$ is present at birth, while acquired HI presents later. About $80 \%$ of $\mathrm{HI}$ in children is congenital (Fortnum, Marshall, \& Summerfield, 2002). Further, a division is made between prelingual and postlingual. Prelingual HI is present before speech and language develop, while a postlingual HI occurs after normal speech and language development has begun (Kochhar, Hildebrand, \& Smith, 2007).

The degree of $\mathrm{HI}$ is determined based on the pure tone average (PTA) better ear hearing level (BEHL) at 500, 1000, 2000, and $4000 \mathrm{~Hz}$, measured in decibel (dB). According to the World Health Organization (2018a), a hearing loss is classified as slight/mild at 26-40 dB, moderate at $41-60 \mathrm{~dB}$, severe at $61-80 \mathrm{~dB}$, and profound at over $81 \mathrm{~dB}$. In children, a hearing loss greater than $30 \mathrm{~dB}$ is regarded as disabling (World Health Organization, 2018a). Alternative classifications exist, such as that of the American Speech-Language-Hearing Association (ASHA), which differs slightly with regards to cut-off values for the different degrees of hearing loss (ASHA, 2018; Clark, 1981). Besides the degree of HI, it is important to determine what frequencies are affected. The HI may be described as low frequency (affecting frequencies $<500$ $\mathrm{Hz})$, middle frequency $(501-2000 \mathrm{~Hz})$, or high frequency $(>2000 \mathrm{~Hz})$ (Kochhar et al., 2007).

HI can further be bilateral, affecting both ears, or unilateral, affecting only one ear. Hearing, as defined by all of the above parameters, may also differ between the ears in one individual.

\section{Prevalence and etiology}

In developed Western countries, about two to three children in 1000 are born with a hearing impairment that is severe enough to impact speech and language development (Finitzo, Albright, \& O'Neal, 1998). Early detection of the HI has proved crucial in the effort to remedy the negative consequences for communication (Niparko et al., 2010), and national programs for universal newborn hearing screening have been introduced in many developed countries. The first Swedish screening program was introduced in 1995 (SBU, 2004), and full nationwide implementation was achieved in 2008 (Socialstyrelsen, 2009). These programs make it possible to detect HI within the first few weeks of life, and to initiate subsequent early intervention. Still, some children are not detected at screening, but have a later-onset or progressive HI (White, Forsman, Eichwald, \& Munoz, 2010). In addition, there is a substantial number of 
refugee and migrant children with $\mathrm{HI}$ who may not be picked up by public health care services.

Hearing impairment can be caused by a large number of factors. More than 400 genetic syndromes have hearing impairment as a characteristic feature, and over 100 genes are associated with nonsyndromic genetic hearing impairment (Alford et al., 2014). Congenital HI is genetic in about $50-60 \%$ of the cases, out of which syndromic causes account for $15 \%$, and nonsyndromic for 35\%. The remaining $40-50 \%$ is caused by environmental factors, such as prematurity, infections, or iatrogenic causes. (Kochhar et al., 2007; Morton \& Nance, 2006). About 30-40\% of children with congenital deafness are estimated to have additional disabilities (Ching et al., 2009). In reality, however, the cause is not known for many children, which is also reflected in the sample of children with HI in the present thesis. The etiology in children with at least moderate sensorineural HI has been shown to be unknown in around $56 \%$ of the cases (Mehra, Eavey, \& Keamy, 2009).

\section{Hearing aids}

The majority of children with sensorineural HI use conventional HA to compensate for their reduced hearing acuity. HA compensate for the hearing impairment by amplification of the acoustic signal, depending on individual hearing characteristics with regards to e.g. degree of $\mathrm{HI}$ and frequencies affected. Incoming sound is captured by a microphone, and converted to electrical signals. These are then processed by a processing unit, and forwarded to a miniature speaker, whose output has greater amplitude than the original signal. Although modern HA technology provides much flexibility and customization options, it cannot compensate for the severe dysfunction or loss of hair cells in the cochlea. Subsequently, individuals with severe enough sensorineural HI may not benefit sufficiently from the use of a HA, but must instead undergo cochlear implantation (Arlinger, 2007).

\section{Cochlear implants}

Children with sensorineural HI who receive limited benefit from HA should be considered for CI. A CI enables children with severe degrees of hearing impairment to hear. The device comprises both external and internal components (Figure 1). The external ones include a microphone, a speech processor (1), and a transmitter coil (2). The internal components consist of a receiver coil (3), containing a magnet and an antenna, mounted on the inside of the skin, and an electrode array (4). Sound is captured by the microphone, which sends electric signals to the processor for further 
conversion into digitally coded information. The transmitter coil sends the information to the receiver. There, the information is converted into electrical signals and sent into the electrode array, which is implanted in the cochlea and stimulates the neural receptors (Zwolan, 2009).

Data collected from all CI-centers in Sweden show 72 children under the age of 18 years received a CI last year (year 2017). If the degree of HI is profound in both ears, implantation is normally performed bilaterally, as bilateral hearing affects speech and language development positively (Niparko et al., 2010). Children with asymmetric $\mathrm{HI}$, e.g. profound $\mathrm{HI}$ in one ear and moderate $\mathrm{HI}$ in the other, may receive a $\mathrm{CI}$ in the profoundly impaired ear, while using a HA in the ear with better hearing (Offeciers et al., 2005). Further, current CI technology also permits partial implantation of a cochlea with residual normal or near normal low frequency hearing, but severe high frequency dysfunction (Skarzynski, Lorens, Piotrowska, \& Anderson, 2007).

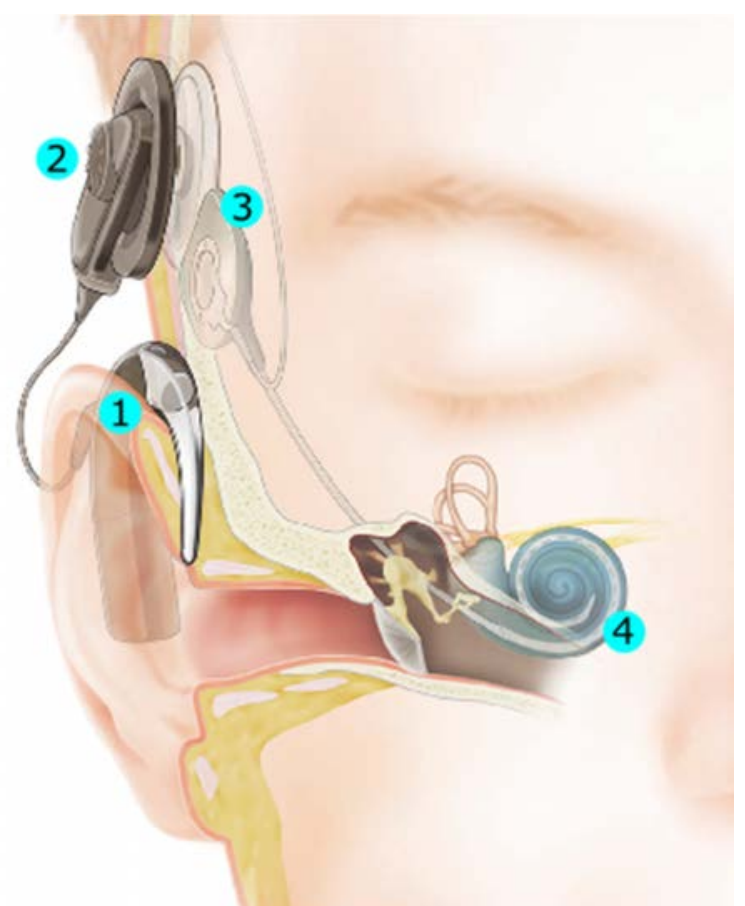

Figure 1. Cochlear implant device in situ (Cochlear). 


\section{Development of speech, language and cognition}

Neural plasticity for the forming of central auditory pathways is greatest within the first 3.5 years of life, but can be large enough to motivate cochlear implantation of congenitally deaf children up until 7 years of age (Sharma, Nash, \& Dorman, 2009). The results of CI are, however, best if done before the second year of life (Kral \& Sharma, 2012), and early implantation is beneficial for subsequent language development (Niparko et al., 2010).

Using the same descriptors as advocated by the CATALISE consortium (Bishop et al., 2017), language deficits present in children with HI would be called language disorder associated with hearing impairment. This does not imply causality, however, and it is reasonable to assume that a proportion of the children with HI would have DLD regardless of their reduced hearing ability (Schwartz, 2009).

The limited auditory sensory stimulation and experience also affect neurocognitive functions not directly related to the sensory loss, such as executive functioningincluding working memory - sequential processing, and concept formation. Children with CI can compensate for the degraded auditory input by relying more on contextual cues, e.g. when listening to speech. However, this comes at the cost of increased listening effort and, as a consequence, there are less resources available for other cognitive functions (Kral, Kronenberger, Pisoni, \& O'Donoghue, 2016). It is also likely that the auditory depravation in less severe hearing impairment, e.g. in children with mild-moderate hearing loss, have similar effects, although not to the same extent (Kronenberger, Beer, Castellanos, Pisoni, \& Miyamoto, 2014).

A HA or CI that is appropriately fitted and functioning provide most children with sufficient hearing for development of spoken language. Successful outcomes are, however, also dependent on the cognitive capacity to process the sound information (Sullivan, 2013). Further, the quality and quantity of intervention from e.g. audiologists and SLPs are important in order for the children to learn to make use of their hearing (Yoshinaga-Itano, 2014).

Spoken language outcomes in children with CI are influenced by several hearingrelated characteristics, and language outcomes are supported by shorter duration of profound HI before implantation, prevalence of residual hearing before implantation, earlier age at implantation, and by the use of auditory-verbal communication. High nonverbal intelligence and faster verbal rehearsal speed also provide advantages for language development (Geers \& Sedey, 2011). Halliday, Tuomainen, and Rosen (2017) found that oral and written language abilities were not linked to the severity of HI, or to age of HI identification, in children with mild to moderate HI aged 8-16. Instead, speech and language performance was predicted by familial language problems, maternal education, and nonverbal ability. 
It has also been shown that the behavior of caregiver and the quality of linguistic input are important factors for the development of speech, language and cognition in children with HI. Responsiveness to the child's communicative needs and initiatives, and the use of strategies that encourage speech language use, such as expansions of utterances and open ended questions have proved to be beneficial (Stika et al., 2015; Szagun \& Stumper, 2012). In a study by Quittner et al. (2013), children using CI displayed more rapid language growth if their mothers engaged actively and positively in interaction, expressing emotional support, positive feedback, as well as respect for the child's autonomy.

In summary, the use of HA and CI provide children who have HI with the opportunity to develop spoken language, but not under the same conditions as children with normal hearing. A number of factors influence the speech and language outcomes, related both to etiology and hearing, intervention, cognitive ability, and support from caregivers and educators. A consistent finding in studies of speech, language and cognition in children with HI is that the degree of heterogeneity is substantial. Many children can reach age-appropriate levels, while others lag behind. 


\section{Phonology}

In spoken language, speech is used to communicate. The human vocal tract enables articulation of a great number of different speech sounds, but only a subset is utilized in any given language. The field of phonology is concerned with how units of speech are organized and used contrastively to convey meaning (Ball, Rutter, \& Müller, 2010).

The elements of speech can be described as segmental or suprasegmental. The segmental aspects of speech include the individual speech sounds (segments). A main division is made into vowels and consonants, based on acoustico-phonetic and functional properties. Vowels are produced with free airflow through the vocal tract, and are typically voiced. They contain more energy than consonants, making them more perceptually prominent. Consonants are articulated with a higher degree of stricture in the vocal tract, giving rise to turbulence. They can be produced with or without voice, and are generally of shorter duration than vowels. Phonologically, the separation of vowels and consonants is made based on how these speech sounds are used in the structure of language. Vowels are normally syllabic, occurring at the center of the syllable, while consonants are grouped around the vowels in the syllable onset or coda.

The sound system of a language entails a number of consonant and vowel phonemes that can be put together to form words. The typical natural language has about 24-31 contrastive speech sounds (Velupillai, 2012). Regardless of how many phonemes there are in a language, this set of meaningless units can be used to form an infinite number of meaningful words and sentences, a phenomenon referred to as double articulation (Martinet, 1949) or duality of patterning (Hockett, 1960). The possibilities for how phonemes can be combined are, however, limited by structure, e.g. constraints on how many consonants that can co-occur in a syllable onset, and by phonotactics, which for instance governs exactly which consonants can occur in an onset, and in what order (Ball, 2016).

The prosodic (or suprasegmental) aspects of speech include features that are not part of individual speech sounds (Cruttenden, 1997). The acoustical correlates of prosody are duration, intensity, and fundamental frequency, with the approximate perceptual counterparts length, loudness and pitch. Together they contribute to the linguistically relevant phenomena of quantity, rhythm, stress, and tone or intonation. Quantity may apply to vowels, consonants, or both in a language, and essentially means that some speech sounds can be lengthened. Stress refers to the relative strength of syllables, and is realized through combinations of vowel quality, duration, pitch and loudness. Depending on the language, stress may be predictable or not; some languages tend to consistently have stress on the same syllable, while others 
have stress that varies between words. The pitch aspects of speech are mainly manifested in the world's languages as tone, working within the domain of the syllable, or intonation, which has the phonological phrase as its domain (Ball, 2016). Prosody serves several important functions in spoken communication. In grouping of segments into separate syllables, words or phrases, prosody is used to signal the boundaries of that which belongs together. Prosodic cues are also used to make some elements more prominent than others, e.g. depending on what information the speaker wishes to highlight. In interaction, prosody is a means of regulating turn-taking, or to convey speaker attitudes and emotions (Bruce, 2012).

Prosody provides a structure for other elements of language. In an utterance, syllables are grouped into words, words into phrases, and phrases into even larger phrases. To enable analyses of the relations between different prosodic elements, and between phonology and syntax, several researchers have proposed a phonological or prosodic hierarchy. The exact levels included in the hierarchy, assumptions of what each level represents, and terminology differ between authors (e.g. Beckman \& Pierrehumbert, 1986; Hayes 1989; McCarthy \& Prince, 1990; Nespor \& Vogel 1986; Selkirk 1981, 1986). The relationship between the levels can partly be described with the Strict Layer Hypothesis, which states that a unit of the hierarchy should be composed of one or more units belonging to the immediately lower level, and that a unit should be completely contained within a unit at the superordinate level (Nespor \& Vogel, 1986). For instance, an intonational phrase should be made up of one or several phonological phrases, a phonological phrase should never belong to several intonational phrases simultaneously.

\section{Swedish lexical phonology}

Swedish as a first language is spoken by around 8.5 million people, mainly in Sweden and Finland (Nationalencyklopedin, 2017). Broadly described, there are three major dialect areas, differing mostly in their prosodic characteristics, but also in segmental properties (Bruce, 2010). The present review will be limited to the regional dialect Central Swedish, which is a general term used for the varieties of Swedish used in mainland Sweden, except for in the southernmost parts. Henceforth, the use of the word Swedish refers to Central Swedish, unless otherwise stated.

\section{Vowels}

The vowel system of Swedish hosts nine vowel phonemes, each with one long and one short allophonic variant, adding up to 18 distinct vowels (Riad, 2014), although 
the short variants of the phonemes /e/ and / $/$ / are often considered to be conflated to one single realization, $[\varepsilon]$. Further, there are context dependent allophones of $/ \varepsilon /$ and /ø/ before /r/, each with one long ([æ:], [œ:]) and a short ([æ], [œ]) variant (Kuronen, 2000), making the total number of vowels 21. Regardless of the exact count, the Swedish vowel inventory is reasonably large (Velupillai, 2012). Additionally, there are three diphthongs, $[\widehat{\mathrm{a \theta}}],[\widehat{\varepsilon \theta}]$ and $[\widehat{\varepsilon u}]$, with some variation in pronunciation, which mainly occur in loan words (Riad, 2014). The Swedish vowels are shown in table 3.

Riad (2014) argues that vowel length is only allophonic, and that contrastive length only applies to consonants. To the contrary, others have claimed that vowel length is indeed contrastive (Linell, 1978). A further description of the relation between segment length and stress is given below.

Table 3. The Swedish vowels (from Elert, 2000).

\begin{tabular}{lll}
\hline Phoneme & Long & Short \\
\hline$/ \mathrm{i} /$ & {$[\mathrm{i}]$} & {$[\mathrm{I}]$} \\
$/ \mathrm{y} /$ & {$[\mathrm{y}:]$} & {$[\mathrm{Y}]$} \\
$/ \mathrm{e} /$ & {$[\mathrm{e}:]$} & {$[\mathrm{e}]$} \\
$/ \varepsilon /$ & {$[\varepsilon:]$} & {$[\varepsilon]$} \\
$/ \varnothing /$ & {$[\varnothing:]$} & {$[\varnothing]$} \\
$/ \mathfrak{u} /$ & {$[\mathrm{t}:]$} & {$[\mathrm{\theta}]$} \\
$/ \mathrm{u} /$ & {$[\mathrm{u}:]$} & {$[\mathrm{U}]$} \\
$/ \mathrm{o} /$ & {$[\mathrm{o}:]$} & {$[\mathrm{O}]$} \\
$/ \mathrm{a} /$ & {$[\mathrm{a}:]$} & {$[\mathrm{a}]$} \\
\hline
\end{tabular}

\section{Consonants}

The Swedish consonant system has 18 consonants, if only qualitative contrasts are considered. But all of these, except $/ \mathrm{c} /$ and $/ \mathrm{h} /$, also come in long and short variants. Riad lists the consonant phonemes as: /p/,/b/,/m/, /f/, /v/, /t/, /d/, /n/, /s/, /l/, /r/, / /, $/ \mathrm{s} /, / \mathrm{j} /, / \mathrm{k} /, / \mathrm{g} /, / \mathrm{y} /$, and $/ \mathrm{h} /$. Realization of the fricative $/ \mathrm{s} /$ may be highly variable both within and between speakers, and the descriptions of the allophonic variants vary in the literature; often, [乌] has been proposed as the main allophonic variant (Riad, 2014). 


\section{Quantity}

The main phonetic correlate for segment quantity is duration, but there are also qualitative differences between the long and short versions of the vowels and consonants. On average, short vowels have a duration amounting to $65 \%$ of that of their long counterparts, while the same relation for consonants is about $75-80 \%$ (Elert, 1964).

Quantity in Swedish is dependent on stress, with a requirement on all stressed syllables to be heavy, i.e. to have two moras (Riad, 2014). The quantity system is expressed in the domain of the syllable rime, with complementary distribution of length between vowels and consonants in stressed syllables. This means that rimes of stressed syllables have either a long vowel (with one or several optional short coda consonants), or a short vowel and a following long consonant (Bruce, 2012). Unstressed syllables do not contain long vowels, and are considered light-i.e. they have only one mora-even if there is a coda consonant after the vowel (Riad, 2014). The quantity system results in long and short variants of most consonants and vowels, and there are many minimal pairs of words that are distinguished by quantity, for example /ma:t/ 'food' - /mat:/ 'faint', and /stø:ta/ 'push' - /støt:a/ 'support'.

\section{Stress}

Lexical stress in Swedish is variable in the sense that stress placement differs between words, but it is also quantity sensitive, which means that only heavy syllables attract stress. A consequence of the variability is that stress can be used distinctively to distinguish word meaning in a number of minimal pairs, e.g. /'formel/ 'formula' /for'mel/ 'formal'. Two main stress patterns can be described: one for simplex forms and one for compounds. In simplex forms, a single main stress is typically assigned to one of the last three syllables. If the word is long, a syllable early in the word may receive a stress-like prominence, but this is due to rhythmical variations at the phrase level rather than a genuine secondary stress. Compounds, on the other hand, have both main and secondary stress. Main stress is assigned to a syllable of the first part of the compound, while secondary stress is assigned to a syllable belonging to the last part (Bruce, 2012).

As described in Bruce (2012), the basic stress pattern for simplex forms is trochaic, i.e. feet are left-dominant (strong-weak), and feet are assigned from right to left. Seemingly contrary to this, Riad (2014) argues that the foot in Swedish always comprises a single stressed syllable because of the fact that stressed syllables must be heavy, i.e. bimoraic. Consequently, the foot structure is non-exhaustive, meaning that not all syllables are parsed into feet, and assignment of feet per default in a right-to- 
left fashion cannot capture the observed stress patterns in a satisfactory manner. Instead, the stress system is lexical in its nature, and is as such largely determined by morphology. With regards to prosody, morphemes in Swedish can be categorized as unspecified or specified. Unspecified morphemes get their stress assignment via a phonological stress rule to the rightmost available syllable of the prosodic word. Prosodically specified morphemes can further be classified as tonic (lexically stressed), pretonic (occurring before the stressed syllable), or posttonic (occurring after the stressed syllable). These three types of specified morphemes bear prosodic specifications as part of their lexical representations, and determine stress placement directly (Riad, 2012, 2014). Experimental evidence for the division into morphemes as specified or unspecified for stress is given by Zora et al. (2016).

\section{Tonal word accent}

Swedish can be categorized as a pitch accent language, and has a tonal accent system with two distinct tonal contours, referred to as tonal word accent 1 ['] and tonal word accent 2 ['] (Cruttenden, 1997). Tonal word accent can be used to distinguish meaning between about 350 pairs of words that otherwise have the same stress pattern and segments, e.g. 'ánden ('the duck'; tonal word accent 1) and 'ànden ('the spirit'; tonal word accent 2). There are also two prominence levels, the lower called word accented, and the higher referred to as focus accented. The realization of the tonal word accent is different in the two prominence conditions, but there is no difference in prominence between the tonal word accents per se (Riad, 2014). Regardless of prominence, tonal word accent is always associated to a stressed syllable, and all words can be argued to have either tonal word accent 1 or 2 . For tonal word accent 1 , the tonal gesture is characterized by a low tone on the stressed syllable followed by a rise. For tonal word accent 2 , there is a high tone followed by a fall on the stressed syllable. If a prosodic word receives focus accent, both tonal word accent 1 and 2 have an additional high tone. The shape of the tonal contours for the tonal word accents is actually quite similar, and a major difference between them is that of the timing in relation to the stress (Bruce, 2012). Compounds almost exclusively have tonal word accent 2. Riad (2014) assumes, in line with the division of the prosodic word into minimal and maximal (Ito \& Mester, 2006), that compounds consist of several minimal prosodic words that together form one maximal prosodic word. Thereby, there are several stressed syllables that can bear tone. Tonal word accent is then associated with the stress of the first minimal prosodic word, which receives tonal word accent 2 , and to the stress of the last minimal prosodic word, which then receives tonal word accent 1 (Riad, 2014). 
The distribution of tonal word accent 2 is limited by the condition that there must be an unstressed syllable after the stressed, tone bearing, syllable. Hence, monosyllabic words and words with stress on the final syllable have tonal word accent 1. All other stress patterns in simplex words enable either tonal word accent 1 or tonal word accent 2 . The choice of tonal word accent is then determined by other factors, mainly morphology. Bruce (Bruce, 1977, 2012) provides some general guidelines to predicting tonal word accent. Identification of the stem is generally not enough, as tonal word accent often is determined by inflectional or derivational suffixes. For example, a monosyllabic word stem like sítt- 'sit' in combination with the infinitive suffix $-\mathrm{a}$ will render tonal word accent 2 sitta 'to sit', but combined with the present tense suffix -er, the result will be tonal word accent 1 sítter 'sits'. In disyllabic word stems with stress on the first syllable, the tonal word accent is already inherent and will not be affected by suffixation.

\section{Typical prosodic and phonological development}

Until about six months of age, the infant child possesses the ability to discriminate between all human speech sounds. But this universal perceptual capacity does not last long, and children grow sensitive to the sound patterns of the language around them already during their first year of life (Vihman, 2013). Before the end of their first year, children no longer have the ability to separate certain speech sounds that are not part of the ambient language. Instead, they have the ability to perceive language-specific speech sounds, sound combinations, and stress patterns (Kuhl, 2004). Infants' vocal production also develops substantially in the first year, from early reflexive vocalizations, through increasingly diversified babbling, to the appearance of word like forms. However, the productive repertoire is limited compared to the ability to perceive sounds (Oller, 1980).

With the emergence of the first meaningful words at around 12 months of age, and the subsequent rapid increase in vocabulary size around 18 months, children begin to use the speech sounds more and more systematically. However, the mere articulation of a speech sound does not mean that it is used phonemically to distinguish meaning, and proper phonological use of all the speech sounds in a language takes several years to master. Sander (1972) outlined a few landmark stages that the child passes through before mastery of a given speech sound is achieved: (1) the production of the sound in any context, (2) the correct articulation of the sound in words, (3) customary production, i.e. the sound is used correctly more often than it is used incorrectly. Mastery is then reached when the child exhibits correct use of the sound most of the time, in all word positions (Sander, 1972). 
Prosody functions as a scaffolding for the detection of important elements of the speech stream (Arbisi-Kelm \& Beckman, 2009). The use of prosody plays an important role in first language acquisition from the beginning (Speer \& Ito, 2009), and sensitivity to prosodic structure has been shown to exist already in newborn infants (Christophe, Mehler, \& Sebastián-Gallés, 2001). Several authors have referred to a process of prosodic bootstrapping, by which infants use prosody to detect e.g. clausal units and phrase boundaries, facilitating the acquisition of syntactic, lexical and phonetic units (Jusczyk, 1997; Morgan \& Demuth, 1996).

Initially, the experience of prosody is presumably purely signal-based, and linguistic meaning is only gradually assigned to the prosodic features of the speech stream (DePaolis, Vihman, \& Kunnari, 2008). However, there appears to be an effect of the prosody of the ambient language before connections to meaning are made (Arbisi-Kelm \& Beckman, 2009). Nine-month-old infants have been shown to segment words based on rhythmical patterns (Echols, Crowhurst, \& Childers, 1997), and there are language specific intonational differences in multisyllabic babble utterances between e.g. French- and English-learning infants at 10 months (de Boysson-Bardies \& Vihman, 1991). Also, the prosody of children's early words reflect the preferred rhythmical patterns of the language they are exposed to (Vihman, DePaolis, \& Davis, 1998).

In a study by Wells et al. (2004) intonation development was examined in typically developing English-speaking children between the ages of 5 and 13, using the Profiling Elements of Prosodic Systems_Child version (PEPS-C; Wells \& Peppé, 2003). Some aspects of prosody were found to be acquired by the age of five years, while others seemingly continued to develop until ten years of age. Furthermore, prosodic ability, particularly comprehension, was related to more general expressive and receptive language skills. The authors concluded that important development of prosody takes place between the ages of 5 and 11 . However, considerable variability can be expected, and weaknesses in some prosodic domains does not necessarily imply weakness in others (Wells et al., 2004).

In Swedish-speaking children phonemically contrastive use can be expected for the consonants /p/, /t/, /k/, /m/, /n/, /v/, /j/ and /h/, and the vowels /a/, /a:/, / $/$ :/, /ui/ and /o:/ before four years of age. Between the ages of four and six, the consonants /b/, /d/, /g/, /y/, /f/, /l/ and /s/ are established, together with the vowels /i/, /I/, /E/, /e:/,

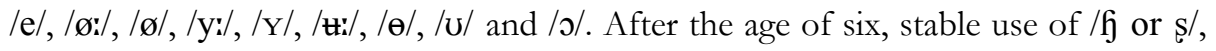
$/ \varsigma /$, and /r/ develops, as well as appropriate production of the retroflexes [t], [d] and [n] (Nettelbladt, 2007), which mainly result from phonological processes when $/ \mathrm{r}$ / occur in combination with /t/, /d/ and /n/ $(\operatorname{Riad}, 2014)$. 
Peters and Strömqvist (1996) showed that tonal word accent 2 is typically acquired first by Swedish-speaking children, supposedly due to greater perceptual saliency compared to tonal word accent 1 in the ambient language. Tonal word accent 2 is realized with a two-peak tonal contour in focused words, which often occur in an utterance-final position, making the perceptual saliency high (Horne, 2013). Disyllabic words produced by 18- and 24-month-old children mainly have a tonal word accent 2 pattern, which is also the most prevalent for two-syllable words in adult speech (Kadin \& Engstrand, 2005). Pitch patterns typical for tonal word accent 2 have also been confirmed in children as young as 16 months (Ota, 2006), but tonal word accent 2-like patterns may be present already at 12 months (Engstrand, Williams, \& Lacerda, 2003). Children begin to alternate between the two tonal word accents when the use of suffixes emerges for plural and definite noun forms, and infinitive and present tense verb forms. This indicates close ties between the tonal word accents and morphology early in development (Peters \& Strömqvist, 1996). However, mastery of the tonal word accents is not achieved until about four years of age (Plunkett \& Strömqvist, 1992), and tonal word accent use has been shown to be problematic for children with DLD (Samuelsson \& Nettelbladt, 2004; Samuelsson, Scocco, \& Nettelbladt, 2003).

\section{Phonological development in children with developmental language disorder}

Many children with DLD have deficits in phonological perception, production, and awareness. These deficits may results in lower intelligibility and reduced language comprehension, affecting everyday communication. Phonological deficits are also relevant to other domains of language. For example, production and perception of morphological and syntactic units are dependent on both segmental and prosodic phonological information (Schwartz, 2009). Early studies of children with DLD were mainly concerned with segmental phonology, and prosody has been somewhat understudied (Bortolini \& Leonard, 2000; Peppé, 2009).

Using their test material Profiling Elements of Prosodic Systems - Child version (PEPSC), Wells \& Peppé (2003) studied intonation in eight-year-old children with DLD using English as their first language compared to groups of controls matched for either age or language comprehension. The children with DLD did not score significantly below the language comprehension controls on any of the intonations tasks, leading the authors to suggest that problems with intonation is likely not the key factor underlying the deficits in other domains of language. However, given the variability among the children with DLD, prosody may play a larger role in some children. The children with DLD also achieved results similar to those of the age-matched controls 
on the majority of intonation tasks, but performed significantly below on judgements of whether two stimuli had the same or different prosody, and on repetition of the prosody in a semantically ambiguous number sequence (e.g. '42, 1' or '40, 2, 1). Children in the DLD group also performed below the age-matched controls on some, but not all, tasks that require the child to make a connection between prosodic form and communicative function. This later finding could indicate prosodic or pragmatic difficulties, or both (Wells \& Peppé, 2003).

Samuelsson, Reuterskiöld, Nettelbladt, and Sahlén (2011) studied production and perception of metrical patterns in Swedish-speaking children with DLD aged four to five years in comparison to controls with typical language development. Prosodic perception of contrastive stress was tested with a task which required the children to use stress to disambiguate meaning in sentences that contained either a stressed verb particle or a stressed verb followed by an unstressed preposition. The verb particle and the preposition had the same position and the same segmental constituents. Depending on stress placement, the sentence could have different meanings, exemplified by the sentence pair mannen skjuter $P A$ en bil 'the man pushes a car' vs. mannen SKJUTER på en bil 'the man shoots at a car'. Production of such stress patterns was tested with a sentence repetition task. The children also repeated sentences containing prestressed indefinite articles and copula, or a poststressed definite form suffix. The results showed that the children with DLD performed below controls on all tasks, and made more omissions of unstressed syllables, the majority of which occurred in prestressed positions. However, the semantic or syntactical context did not appear to matter for syllable omissions, as unstressed syllables within content words were omitted to the same extent as free-standing, unstressed, grammatical morphemes, such as copulas (Samuelsson et al., 2011).

Samuelsson and Nettelbladt (2004) studied Swedish-speaking children with DLD who had been identified with some degree of prosodic problems by their clinicians. An assessment material with tasks measuring prosody at the word, phrase, and discourse levels was used. The children with DLD performed significantly below controls with typical language development on all tasks. In order to relate individual performance in the group with DLD to the controls, cut-off scores for low performance were determined for each of the levels. At the discourse level, $92 \%$ of the children achieved low scores. Further, 33\% of the children with DLD scored low at the word level but not at the phrase level, while $42 \%$ obtained low scores at both the word and the phrase level. Based on examinations of individual performance, the authors also suggested a categorization of the children with DLD into two subgroups: one whose problems are primarily phonetic and linguistic, and one whose problems are related to pragmatic problems. 
Difficulties with tonal words accents are prevalent in children with DLD. According to Nettelbladt (1983), overgeneralization of tonal word accent 2 is the most common error, i.e. the use of tonal word accent 2 in words which should have tonal word accent 1 . This assumption of overgeneralization was, however, based on perceptual evaluations, which may be influenced by categorical perception in adult listeners. Addressing the problem that most studies of tonal word accent use in children with DLD only use perceptual judgments, Samuelsson and Löfqvist (2006) employed both acoustic and perceptual analyses of tonal word accent production. Assessments based on narrow-band spectrograms confirmed that tonal word accent production was indeed problematic for the children in their sample of four- to ten-year-old children with DLD. The acoustic analyses could not confirm that overgeneralization of one tonal word accent for the other was the main error pattern. Instead, tonal word accent errors were characterized by a lack of clearly distinguishable f0-patterns and contrasts between the two tonal word accents (Samuelsson \& Löfqvist, 2006).

To summarize, prosody in children with DLD seems to be relatively unimpaired compared to e.g. phonology and grammar, but there is a high degree of variability. In some children, prosodic difficulties are more closely related to problems in different areas of language ability, while others may display age-appropriate prosodic skills despite impairments of e.g. grammar.

\section{Phonological development in children with hearing impairment}

The present thesis included children with sensorineural mild-profound HI receiving three different types of auditory stimulation: through bilateral CI, bilateral HA, or bimodally through both CI and HA simultaneously. CI and HA use different technologies, and as such provide different hearing conditions. HA uses amplification of the acoustic signal to make sounds louder, but the inner ear must be sufficiently functional for hearing to occur. A CI processes the acoustic signal, and converts it to electrical impulses, stimulating the cochlea and auditory nerve directly through an array of electrodes. Although there have been significant improvements in technology, some aspects of the sound signal cannot be conveyed by the CI.

\section{Studies of phonological development in children with CI}

The technology of cochlear implants gives limited access to speech and language compared to normal hearing because of the reduced spectral and temporal resolution. This mainly affects the ability to perceive fundamental frequency and amplitude, while per- 
ception of duration is not as constrained (Moore, 2003). Potentially, there are detrimental effects on the acquisition of all aspects of auditorily based learning, including the acquisition of consonants and vowels (Geers, 2003), intonation (Peng, Tomblin, $\&$ Turner, 2008), stress in words and sentences (Titterington, Henry, Krämer, Toner, \& Stevenson, 2006; Torppa et al., 2014), affective prosody (Nakata, Trehub, \& Kanda, 2012), as well as music (Limb \& Roy, 2014). Although fundamental frequency is presumed to be the most important cue to stress and intonation, there is research that suggests that duration can provide CI users with important cues to such prosodic features (Hegarty \& Faulkner, 2013). In general, variability in speech and language outcomes is large in children receiving CI, and individual outcomes are dependent on the onset, duration, and severity of the HI, and on cognitive factors (Kral et al., 2016).

\section{Speech sound development}

After implantation, speech perception for vowels and consonants improves, and the gains in perception also seem to benefit phonological production (Faes, Gillis, \& Gillis, 2016), although development may be affected by the age at which the child was implanted (Liu et al., 2015). The developmental trajectory for consonant and vowel use is partly similar for children with CI and children with typical development, but there are also differences. Ertmer and Goffman (2011) studied six English-speaking children with bilateral CI aged three-five years, who had been implanted before three years of age, and six typically developing controls. Word initial stop, nasal and glide consonants were produced more accurately than fricatives, affricates and liquids by the children with CI, which is expected also for children with typical development. Accuracy was lower, and variability higher, for both consonant and vowel production for the children with CI. Contrary to expectations for typically developing children, the children with CI displayed a reverse order of development for some fricatives and affricates. For instance, voiced [v] and [z] appeared easier to produce than the voiceless counterparts [f] and [s], perhaps due to differences in perceptual saliency. Production accuracy was higher overall for vowels than for consonants in the group with CI, although variability was greater than for the children with $\mathrm{NH}$ (Ertmer \& Goffman, 2011).

Spencer and Guo (2013) investigated consonant development in 32 Englishspeaking children with unilateral CI in a longitudinal study. All children were implanted before 30 months of age, and speech production data were collected with the Goldman-Fristoe Test of Articulation-2 at 12, 24, 36, and 48 months after CI activation. The results showed that the children with $\mathrm{CI}$ produced consonants within age norms within four years of CI use, and the order of consonant development was consistent with that of children with normal hearing (Spencer \& Guo, 2013). 
In a study of phonological accuracy, Faes et al. (2016) followed a group of Dutchspeaking children with CI from when they were implanted up until the age of 5 years. Overall, phonemic accuracy was found to be lower for the children with CI compared to children with $\mathrm{NH}$, but this difference was not significant. Before the age of four, the children with $\mathrm{CI}$ achieved results comparable to those of their peers with $\mathrm{NH}$ in shorter words, while phonemic accuracy in long, complex words were more problematic. A further finding was that age at implantation appeared to have no effect on phonemic accuracy (Faes et al., 2016), which is contrary to earlier studies (e.g. Nicholas \& Geers, 2007). A possible explanation for the insignificant group differences is that the children in the Faes et al. study had a mean age at implantation of only one year.

In many respects, children with CI can achieve an ability to use segmentals close to that of normal hearing children, but development is likely dependent on early hearing impairment detection and implantation. Different categories of speech sounds pose varying degrees of difficulty. Most notably, vowels are easier to use than consonants. Within the consonant category, fricatives and liquids appear to be the most difficult.

\section{Prosodic development}

Pettinato and colleagues (2017) examined pitch, intensity and duration in young children with CI and children with NH. The children with CI were recorded multiple times beginning at the onset of canonical babbling (mean chronological age was 17 months), and continuing until the child had a vocabulary of 200 words. In general, the children with CI did not show as clear a development of the ability to use prosodic cues as the children with NH. This was clearest for pitch, as the children with CI displayed lesser pitch range in disyllabic sequences compared to children with NH. The results also indicated that there was an increase in pitch variation over time in both children with $\mathrm{CI}$ and $\mathrm{NH}$, although the largest increase occurred for the children with NH. The children with NH also began to use a more consistently trochaic disyllabic pitch pattern after the transition from babble to words, while such development was not as clear for the children with CI (Pettinato et al., 2017).

Segal et al. (2016) found that infants in Hebrew-speaking families implanted with CI before the age of 2.5 years could discriminate between different stress patterns after less than 6 months of CI use. They also showed a preference for the predominant trochaic lexical stress pattern in Hebrew, similar to infants with normal hearing. CI appear to provide enough auditory input for infants to make use of the prosodic cues in the ambient language, although not to the same extent as normal hearing children. 
Peng et al. (2008) investigated prosody in English-speaking children, adolescents and young adults between 7 and 20 years of age with HI who had received CI between the ages of 1.5 and 6.3. The children with CI had lower ability to produce and perceive intonation for declarative and interrogative sentences in comparison to children with normal hearing. Production and perception were generally positively related, although variability was high among the children with CI, and there were children who displayed good perception of prosody but low production, and vice versa (Peng et al., 2008). A discrepancy between perception and production was also found by O'Halpin (2010) for children and adolescents with CI aged 5-17 years.

More recently, Moein and colleagues (2017) studied the ability to use intonation to produce and perceive declarative and interrogative sentences in Farsi-speaking children with CI, aged 7-11 years. Compared to children with normal hearing, the children with CI were less able to disambiguate questions from statements by the use of intonation, in perception and production alike. Based on correlational analyses, early implantation and long-time use of the CI emerged as beneficial factors for prosodic ability (Moein et al., 2017).

Titterington et al. (2006) investigated the effect of prosodic position on the processing of unstressed syllables in 20 children with CI aged around 8-12 years of age, out of which 15 were developing language as expected, and five had confirmed concurrent speech and language difficulties. Controls with NH, matched for either chronological or language age, were also included. The test material comprised nonword and sentence repetition tasks, elicitation of spontaneous speech, and a memory task requiring the children to discriminate between consonants in the onsets of strong and weak syllables. Further, standardized tests of speech, language and short-term memory were administered. Unstressed syllables were processed less well by the children with CI compared to the controls. Unstressed syllables occurring outside of the trochaic foot were also produced less often than unstressed syllables occurring within the trochaic foot. However, the children with CI who had confirmed difficulties with speech and language did not show a preference for trochaic foot structure, which sets them apart both from the other children with CI, and younger typically developing children. The authors suggested that weak syllable use may be used to discriminate children with CI who have speech and language difficulties from those that do not. Further, all speech and language measures were significantly correlated with the processing of unstressed syllables, and regression analyses indicated that grammatical morpheme use significantly predicted the use of unstressed syllables outside of the trochaic foot. This could indicate that the ability to perceive and produce such syllables is important for the acquisition of grammatical morphemes in English (Titterington et al., 2006). 
Holt, Demuth and Yuen (2016) examined the use of prosodic cues in a study of individuals with CI, aged 13-18 years. A phoneme monitoring task, in which participants were asked to push a button as quickly as possible when they heard certain target speech sounds, was administered. Target sounds occurred in words that were either focused, i.e. received the pitch accent of the sentence, or not. The participants with CI were able to use the prosodic cues, as evidenced by faster reaction times for target sounds in focused than non-focused words. However, their reaction times were significantly longer compared to those of the controls. Thus, adolescents with HI who wear CI appear to benefit from prosodic cues to identify important elements in the speech stream, but not to the same extent as adolescents with normal hearing (Holt et al., 2016).

In summary, children with CI improve their prosodic ability after implantation, and may largely follow the same developmental trajectories for phonology as children with normal hearing, albeit at a slower pace.

\section{Studies of phonological development in children with $\mathrm{HA}$}

Children with mild-moderate HI are typically candidates for HA use. The HA provides sufficient hearing for development of spoken language, and many children with $\mathrm{HA}$ reach age-appropriate speech and language abilities. However, the HI puts the children at risk for deficits in detection of frequency and amplitude modulation, frequency discrimination, and the ability to discriminate and categorize speech information (Moore, 2007). Even though many children with HI who wear HA achieve age-appropriate level of speech and language proficiency, any degree of hearing impairment increases the risk of speech and language difficulties (Delage \& Tuller, 2007). As is the case with children who use CI, individual variation among children with HA is large (Moeller et al., 2010).

Studies of language development in children who have mild-moderate hearing impairment are rare (Moeller et al., 2010). Halliday et al. (2017) investigated various language abilities in 90 English-speaking participants between 8 and 16 years of age with mild-moderate HI. Scores on standardized measures of grammatical comprehension, expressive vocabulary, nonword repetition, and sentence recall were significantly lower for the children with HI compared to age-matched controls with NH, although many children with HI performed within the age-appropriate limits when standardized test norms were considered. Parental reports of the children's communicative abilities were also lower in the HI group compared to the NH group. In contrast to said findings, the children with $\mathrm{HI}$ achieved similar results as the children with $\mathrm{NH}$ on tests of receptive vocabulary, and word and nonword reading. 


\section{Speech sound development}

Borg, Edquist, Reinholdson, Risberg, and McAllister (2007), showed that Swedishspeaking four- to six-year-olds with mild-severe HI had particular difficulties discriminating between the fricatives $[\mathrm{s}]$ and $[\mathrm{c}]$, while the difference between $[\mathrm{t}]$ and $[\mathrm{d}]$ was the simplest to perceive. Eisenberg (2007) presented a review of speech perception and production in children with HI. In general children with mild-severe HI have higher results on measures of the perception of phonological contrasts and word recognition compared to children with profound $\mathrm{HI}$, but still lower than children with NH. Data in the reviewed studies were mostly from the time before programs for early detection of hearing impairment were in practice on a large scale. Improvements in hearing screening routines, audiological intervention, and hearing aid technology mean that the results from earlier generations of children with HI are not necessarily valid for children who have been identified with HI since. However, more recent studies also indicate that problems with phonology are common in children with mild to moderate or severe HI.

Some studies have found that children with mild-moderate HI have lower phonological processing abilities_-such as phonological discrimination of minimal pairs of words, phonological awareness, and nonwords repetition - while more general language and reading abilities may be within the expected range for children with $\mathrm{NH}$ (Briscoe, Bishop, \& Norbury, 2001; Wake et al., 2006). Findings from other research does not support this discrepancy between phonological ability and other language skills. Delage and Tuller (2007) found phonology to be one of the weakest areas of language in 19 French-speaking children with mild-moderate HI aged 11-15 years. The children also displayed low performance on measures of morphology and syntax, which were significantly correlated with phonological ability.

Briscoe et al. (2001) found that 5-10-year-olds with mild-moderate HI using spoken English as their first language had the same levels of phonological difficulties as children with DLD, as indicated by measures of phonological short-term memory, phonological awareness, and phonological discrimination. Despite this apparent phonological impairment, the children with HI did not show extensive problems with language and literacy compared to children with $\mathrm{NH}$, suggesting that phonological problems are more isolated than in children with DLD.

\section{Prosodic development}

Borg et al. (2007) studied speech and language development in 156 Swedish-speaking children with mild-severe HI aged four to six years. Prosodic production of word 
stress and prosodic phrase focus, i.e. to stress the right word in a sentence, was assessed. Results showed that words with final stress were harder to produce than words with initial stress. There were also some indications that the children with moderatesevere HI had problems stressing the right word in the sentence repetition task, although the results were not unanimous. Further, the children with HI showed better phonological production performance in two-syllable words compared to one- or three-syllable words.

To conclude this section of phonological and prosodic development in children with $\mathrm{CI}$ and HA provide access to spoken language, some children achieve speech and language levels that are adequate with regards to communication needs in relation to age. However, a considerable proportion of children with $\mathrm{HI}$ risks enduring speech and language problems. The technical limitations together with factors concerning age at identification of the hearing impairment, age at implantation or HA fitting, quality of audiological habilitation, speech and language stimulation in everyday life, socio-economic status, and educational setting, are important to development.

\section{The relation between prosody and language ability}

Prosody functions to hold units of linguistic content together, enabling them to be held in memory while they are processed and thereby comprehended (Frazier, Carlson, \& Clifton Jr, 2006). During language development, the role of prosody may vary. Snow (2015), for instance, proposed that prosody is important early in development, while semantic and grammatical cues tend to be incorporated in language learning somewhat later. In line with such reasoning, the dependencies between prosody and grammar likely change over time. The deviant language development characteristic for children with DLD may include problems with prosody, and at least for some children, prosody could play an important role for the acquisition of grammar for longer than what is expected in children with typical language development.

Marshall, Harcourt-Brown, Ramus, and van der Lely (2009) investigated prosody in relation to language ability in children with DLD, dyslexia, or combined DLD aged 10 to 14 years. A number of tasks from the Profiling Elements of Prosodic Systems - Child version (PEPS-C) (Wells \& Peppé, 2003) were administered. A chunking task was used to assess the ability to use prosodic phrasing to express and perceive sentences whose meaning is disambiguated by prosody. The children also performed a focus task, requiring production of focus of the most important information in an utterance using intonation and stress in production, and the use of the same prosodic features to correctly interpret spoken utterances. Further, the children judged whether 
the prosody of two utterances were the same or different in a task where all semantic content had been removed, and they were also given a task containing repetition of prosody as exactly as possible. The children with DLD displayed low performance compared to controls on the tasks which required perception of chunking and focus of linguistic content, while they had no problems with imitation or discrimination of prosody. The results suggested that the interface between prosodic form and linguistic function may be problematic for children with DLD, but that prosodic ability per se is not impaired. Further, the expressive and receptive prosody tasks were not correlated to general language, including other measures of phonology, or phonological memory (digit span and sentence repetition). The authors concluded that prosody does not seem to underlie the language problems in this group, and that problems with phonology does not necessarily include prosodic difficulties in children aged 1014.

Gordon and colleagues (Gordon, Fehd, \& McCandliss, 2015; Gordon, Jacobs, Schuele, \& McAuley, 2015; Gordon, Shivers, et al., 2015) maintain the idea of rhythm as a crucial component in grammatical learning, partly evidenced by the connection of grammar to music. Gordon et al. (2015) suggest that prosody plays an important part in speech segmentation and the acquisition of grammar during development. In children with DLD, concomitant problems with grammar and musical rhythm have been found. Children who are better at perceiving musical rhythms are hypothesized to be more sensitive to variations in linguistic rhythm, yielding an advantage for detecting grammatical elements. Gordon et al. (2015) found an association between musical rhythm discrimination and syntactic ability. This suggests that children who have problems with the perception of rhythm in music are also less able to use rhythmical cues to identify and use morpho-syntactic structures. Subsequently differences in grammatical ability could in part be attributed to differences in the ability to discriminate rhythm, and intervention targeting musical rhythm skills may benefit the acquisition of grammar (Gordon, Shivers, et al., 2015).

Samuelsson et al. (2003) found that prosodic ability was correlated with grammatical abilities and language comprehension in a group of children with DLD, suggesting that problems with prosody might be related to severity of language disorder. 


\section{Immediate repetition}

The observation that children are able imitators, and that they use imitation to learn many things, including language, is commonplace (Brown, 2007), and research has indeed provided evidence that imitation is one of the foundations for learning. Infants imitate gestures and facial movements within the first hour of life, and imitation is an important part of social learning and behavior throughout development (Trevarthen \& Aitken, 2001) and into adulthood (Meltzoff, Kuhl, Movellan, \& Sejnowski, 2009).

\section{Word and nonword repetition}

Nonwords can generally be described as word-sized phonological forms that have no meaning in a specific language. The phonological components of nonwords minimally include a sequence of speech sounds. A nonword can be constructed to be more or less similar to existing words; speech sounds that are either in the language or not can be used, stress patterns and intonation can be more or less language typical, and the length of the nonwords can be varied. The obvious difference between WR and NWR is that the former implicates repetition of meaningful word forms that are represented in long-term memory, while the latter does not. The basic administration of WR or NWR tasks includes telling the person participating that they will hear something (e.g. 'words' or 'made-up words'), and that they should say back what they hear immediately, as exactly as possible. The stimuli may be presented orally by the examiner, or from a recording.

\section{Word and nonword repetition in children with developmental language disor- der}

Due to the large variation in speech and language ability in children with DLD, separating typical from atypical development is challenging (Bishop et al., 2016). However, a number of potential so called clinical markers for DLD have been proposed. NWR is one such marker, which has been shown to differentiate between children with and without DLD in a number of languages (Conti-Ramsden, Botting, \& Faragher, 2001; Dispaldro, Leonard, \& Deevy, 2013b; Girbau, 2016; Kalnak, Peyrard-Janvid, Forssberg, \& Sahlén, 2014). Although the overall difference in NWR ability between children with DLD and TLD is large across studies, the diagnostic accuracy depends on the task and stimuli used. Further, results obtained in research may not translate to clinical use (Graf Estes, Evans, \& Else-Quest, 2007).

Bishop et al. (1996) examined monozygotic and dizygotic pairs of twins, where at least one child in each pair had a language disorder. The twins in the monozygotic 
pairs exhibited more similar NWR performance than did the dizygotic twins, suggesting that NWR is affected by genetic factors. This suggests that genetic factors are important for NWR performance, assuming that environmental influences were the same for both twins in all pairs. Further, when comparing the monozygotic and dizygotic co-twins of children with persistent language disorder, it was revealed that the monozygotic co-twins had lower NWR scores compared to dizygotic co-twins. This finding was interpreted as evidence for a shared genetic influence on both NWR and SLI, suggesting that NWR is a potential behavioral marker for the SLI phenotype (Bishop et al., 1996).

Word repetition (WR) has not been investigated as thoroughly as NWR for the purpose of identifying children who are at risk of language deficits, although WR accuracy has been found to be lower in children with DLD, compared to children with TLD, who speak English (Chiat \& Roy, 2007; Hockey, 2014) and Italian (Dispaldro et al., 2013b).

\section{Word and nonword repetition in children with hearing impairment}

NWR has been found to be difficult for children with all degrees of $\mathrm{HI}$ wearing CI or HA, both regarding segmental features (Briscoe et al., 2001; Dillon, Cleary, Pisoni, \& Carter, 2004; Halliday et al., 2017), and prosody (Carter, Dillon, \& Pisoni, 2002). NWR may further be a good predictor of language development in children with CI (Nittrouer, Caldwell-Tarr, Sansom, Twersky, \& Lowenstein, 2014).

Carter et al. (2002) found that both the ability to repeat word length and stress placement in nonwords was related to measures of short-term memory, language comprehension, and speech intelligibility. Dillon et al. (2004) found the same relations between these measures and segment repetition in children with CI aged eight to nine years. Nonword repetition at age eight to ten years has also been found to be a strong predictor of language performance at 16--18 years of age, in children with CI (Casserly \& Pisoni, 2013).

Studies of Swedish-speaking children with HI have shown that repetition of consonants, vowels and stress patterns are problematic (Ibertsson, Willstedt-Svensson, Radeborg, \& Sahlén, 2008; Nakeva von Mentzer et al., 2015; Wass, 2009). As such, NWR seems to have potential as a useful tool for identifying children with HI who have language problems. 


\section{Theoretical frameworks for word and nonword repetition}

\section{Working memory}

The term working memory (WM) is used to describe the ability of the brain to simultaneously store and process information over a short period of time. This ability is crucial in most complex cognitive tasks, including learning, reasoning, problem solving, and comprehending language (Baddeley, 1992, 2012). Several models of WM have been proposed (e.g. Baddeley, 2000; Baddeley \& Hitch, 1974; Cowan, 1999; Ericsson $\&$ Kintsch, 1995; Oberauer, 2002), but the focus here will be on the multi-component model of working memory (Baddeley, 2000, 2012; Baddeley \& Hitch, 1974).

\section{The multi-component model of working memory}

Originally, the multi-component model of WM was presented by Baddeley and Hitch (1974). This early version contained three components: a control system with limited attentional capacity, the central executive, and two subsystems for the temporary retention of visual and verbal information, named the visuo-spatial sketchpad and the articulatory loop, respectively. The articulatory loop was later renamed the phonological loop. Baddeley (2000) added a fourth component, the episodic buffer, which is a limited capacity store that enables integration of information from the visual-spatial sketchpad, the phonological loop, and long-term memory.

The central executive component is a resource limited control system for attention. Its role is to regulate behavior by focusing attention on a task, dividing attention between tasks, or switching attention between tasks (Baddeley, 2012). In doing this, it interacts with the temporary stores for different kinds of information, the visuospatial sketchpad and the phonological loop (Baddeley, Hitch, \& Allen, 2009).

The episodic buffer is an interface between the other components of WM, as well as between working memory and long-term memory, or perception. In the buffer, information can be integrated and temporarily stored, thus binding e.g. auditive and visual information together with long-term knowledge. The stored, integrated information can then be retrieved and modified by the central executive through conscious awareness (Baddeley, 2000).

The visuo-spatial sketchpad is specialized in storage and manipulation of visual and spatial information (Baddeley, 2003). There is some evidence to suggest separate subsystems for the handling of visual and spatial, respectively, both of which are related to visual attention (Repovš \& Baddeley, 2006).

The phonological loop is most important for the understanding of immediate repetition within the multi-component WM model. It comprises a phonological store, able 
to retain phonological or acoustic memory traces for a few seconds, and a rehearsal process which makes it possible to retrieve and keep active the information held in the store, preventing decay. Information that is already phonologically coded, such as speech, enters the store automatically. Other information, e.g. from the visual modality, can be recoded into phonological form by the rehearsal process (Baddeley, 2003). According to Baddeley et al. (1998), NWR provides a relatively pure measure of phonological loop capacity. The reason for this is the lack of support from existing lexical representations. Both the phonological store and the rehearsal process may be involved in NWR, but the ability for subvocal rehearsal appears to develop first around the age of seven (Cowan \& Kail, 1996).

Vallar and Papagno (2002) presented a more detailed account of the phonological loop, based on data from persons with short-term memory deficits following brain injury. Auditory input undergoes phonological analysis, and is then fed into the phonological store. From the store, the information can be forwarded to a phonological output buffer. It can then be maintained through subvocal rehearsal, or articulated overtly, in which case the information re-enters the system through the hearing modality. Visual input, such as written text, is recoded into phonological units, and can then be forwarded to the phonological output buffer for rehearsal or articulation.

The phonological loop has been shown to be important for language comprehension under certain challenging conditions, e.g. when sentences are long and complex (Lauro, Reis, Cohen, Cecchetto, \& Papagno, 2010; Vallar \& Baddeley, 1987). However, the main function of the phonological loop may not be to remember sequences of known words, but to enable memory for unknown words in order for a person to learn them. As such, the phonological loop supports language learning, especially vocabulary acquisition, in children (Baddeley et al., 1998; Gathercole, 2006). 


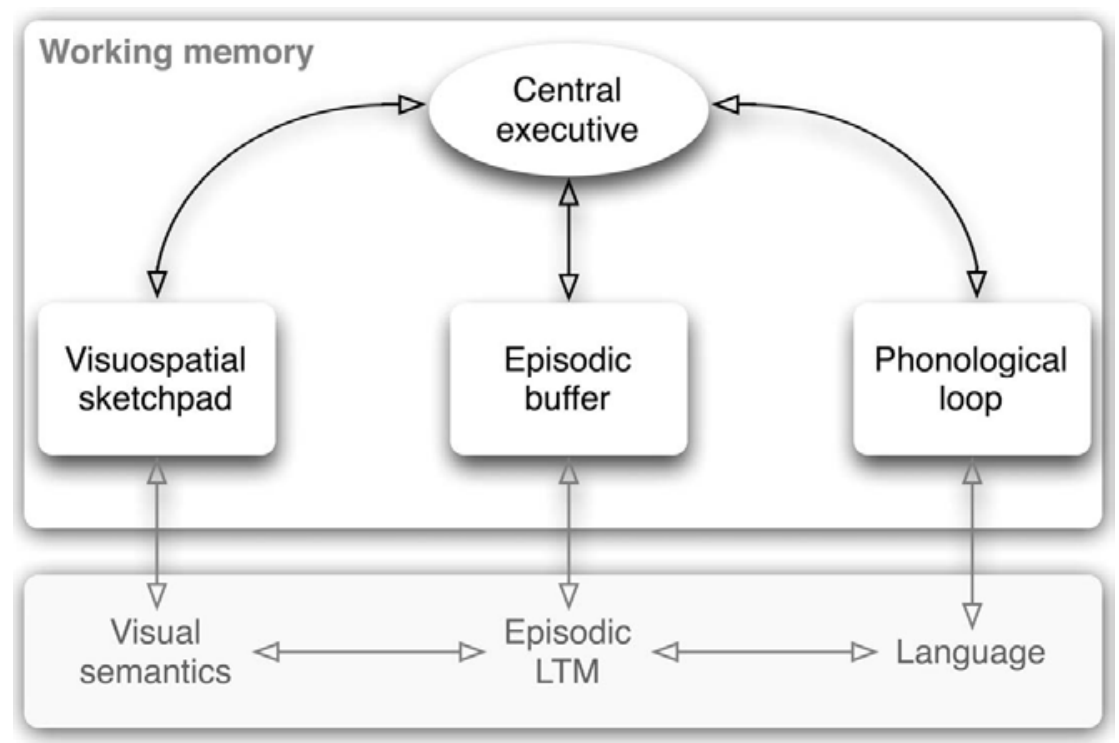

Figure 2. The multi-component model of working memory.

\section{The phonological processing account of NWR}

Beyond the phonological loop, there are supposedly a number of other components involved in handling the nonword information. According to the phonological processing account (e.g. Bowey, 1996; Chiat, 2001; Snowling, Chiat, \& Hulme, 1991), NWR is dependent on phonological processing skills, such as speech perception, construction and encoding of phonological representations in the phonological store, maintenance of the phonological sequence in the store, and programming of articulatory movements. Consequently, problems with any of these components may affect NWR performance negatively. For example, the finding that children with DLD have considerable problems with repetition of longer nonwords, compared to children with TLD, could be explained not only by limited phonological store capacity, but also by lower quality of the phonological representations encoded in the store, as less stable representations are more prone to interference and decay (Bowey, 2006).

The lexical restructuring bypothesis (Metsala \& Walley, 1998), supposes that the words in children's beginning vocabularies are encoded as holistic sound patterns that exist in relation to other words, as opposed to sequences of individual phonemes that can be used regardless of context. As the number of words increases, there is a demand for more efficient storage of the lexical items, which results in more fine grained representations. Eventually, words become specified for their individual sound components, and the child can use these autonomous components to analyze and produce new words. The restructuring takes place gradually, with frequently occurring words 
and words in dense lexical neighborhoods (i.e. clusters of words that are phonologically similar) being restructured earlier. Restructuring facilitates further vocabulary growth (Metsala \& Walley, 1998), as well as NWR (Metsala, 1999).

\section{Repetition and language ability}

If one adopts the definition of nonwords as being potential words in a language (i.e. an allowed sequences of speech-sounds, but without meaning), all words that are unknown to a child could in fact be regarded as nonwords. NWR can thus be said to emulate part of the first encounter with a word, and so also a crucial part of word learning (Gathercole, 2006). In line with this, several studies have shown that children who perform well on standardized measures of vocabulary tend to be good at nonword repetition (see Coady \& Evans, 2008). However, Melby-Lervåg et al. (2012) examined the relationship between NWR and receptive vocabulary in a longitudinal study of 219 Norwegian-speaking children, and they also re-analyzed data from Gathercole, Willis, Emslie, and Baddeley (1992). Their results provided no evidence that NWR was a causal factor in vocabulary growth between four and seven years of age, a period when a rapid increase in vocabulary size can be expected (Melby-Lervåg et al., 2012). Some researchers have argued that the NWR-vocabulary relationship may instead be reversed, proposing that improvements in NWR ability is a consequence of growing vocabulary knowledge (Bowey, 2001; Metsala, 1999). In their review, Coady and Evans (2008) concluded that the relationship between NWR and vocabulary is likely bidirectional.

While the potential relationship between immediate repetition and vocabulary has spurred a considerable number of studies, less interest has been taken in the role of repetition skills in grammatical acquisition and ability. The assumption that sufficient phonological working memory capacity is important in vocabulary learning could, however, quite easily be extended to the acquisition of morphological and syntactical elements, since these comprise words or parts of words (Baddeley et al., 1998).

The results from a series of studies by Adams and Gathercole (Adams \& Gathercole, 1995, 1996, 2000), indicated that typically developing three- to five-yearold children with low phonological WM capacity, indexed by nonword repetition, exhibited less complex grammatical production in spoken narratives compared to children with high phonological WM capacity. The utterances of the low phonological WM group were shorter, measured as mean length of utterance (MLU), and had less syntactical complexity and variation.

Dispaldro, Benelli, Marcolini, and Stella (2009) found that both nonword and word repetition was predictive of grammatical ability (production of $3^{\text {rd }}$ person present tense plural inflection and direct object clitic pronouns) in typically developing 
Italian-speaking children aged 3-4 years. However, they concluded that real word repetition was a stronger predictor, and proposed that word repetition better reflects more general linguistic competence, as it taxes lexico-semantic knowledge more. In a subsequent study, Dispaldro and colleagues (2011) examined whether the predictive use of nonword and real word repetition held cross-linguistically, comparing children with typical language development, speaking Italian and English respectively. Nonword repetition predicted grammatical ability in both groups of children, while word repetition predicted grammar in Italian-speaking children only. This suggests variations across languages regarding the relationship between word repetition and grammar, and that the usefulness of word repetition as an indicator of grammatical ability is likely dependent on the morphological properties of a given language. Extending their investigation of the link between repetition and grammar to Italian children with specific language impairment (SLI), Dispaldro, Leonard, and Deevy (2013a) showed that nonword repetition was predictive of grammatical ability in SLI, whereas word repetition was not. The authors interpret this lack of association of word repetition performance to grammar as an indication that the ability to use third person plural inflection of verbs and direct-object clitic pronouns are less tied to lexical skills compared to in typically developing children.

\section{Summary}

To summarize this introduction, previous research has shown that phonologicalincluding prosodic — deficits are prevalent in children with DLD, as well as in children with HI. Despite the fact that children with DLD and children with HI develop language under different conditions - with and without normal hearing - they may exhibit similar language difficulties. Another area of difficulty common to these groups concerns immediate repetition of novel word forms without meaning, i.e. nonwords, and to some extent also repetition of known words. NWR in particular appears to be a potential indicator of language ability in children with DLD and children with HI. Successful repetition performance in NWR tasks relies on both phonological working memory, phonological processing skills, and existing language knowledge. Still, it has not been made clear exactly what NWR measures. The complexity of the task together with its potential predictive usefulness, calls for close examination of how various features of words and nonwords contribute to repetition performance, and how the ability to repeat these features relate to language ability. The role of prosodic features 
in repetition has not been as extensively studied as repetition of consonants and vowels. In the present thesis, focus is on the ability of children with DLD and HI to use word level prosody in the context of WR and NWR. 


\section{AIMS AND RESEARCH QUESTIONS}

The overall aim of the present thesis is to study word level phonology, with special focus on prosody, in children with DLD and children with HI. A further aim is to describe phonological difficulties in these groups, and to explore the potential diagnostic usefulness of a word and nonword repetition task that takes prosodic features into account. The following general research questions are addressed:

- What is characteristic of prosodic and phonological production in word and nonword repetition in children with DLD and children with HI, and in children with TLD and normal hearing?

- What relation does the ability to repeat prosodic features have to language ability in children with DLD and children with HI?

- What similarities and differences are there between children with DLD, children with HI, and children with TLD, regarding phonological production and expressive grammar? 


\section{METHOD}

\section{Participants and recruitment}

A total of 117 children participated in the studies comprising the present thesis: 30 with DLD (Studies II and IV), 14 with HI (Studies III and IV), and 73 with TLD (44 in study I, and 29 in studies II, III and IV). Recruitment of the clinical groups was made through SLP and audiology clinics, while children with TLD were recruited through preschools or personal contacts.

\section{Children with developmental language disorder}

Studies II and IV in the present thesis included children with DLD. The 30 children (20 male) with DLD were aged 4;1-6;2 (years;months, $M=4 ; 11$ ). Inclusion criteria were: Age four to six years, spoken Swedish as first language, a diagnosis of DLD according to Swedish clinical practice, with mainly phonological and/or grammatical problems. Exclusion criteria were: Multilingualism, pronounced lexical, semantic or pragmatic deficits, known or suspected neurodevelopmental or psychiatric disorders, hearing impairment or history of impaired hearing, e.g. due to recurrent otitis media with effusion.

Information letters were distributed to the caregivers of 142 children with DLD. Written consent to participate was obtained for 40 of the children. Ten children were lost because of illness, difficulties finding a suitable time for testing, or multilingualism.

\section{Children with hearing impairment}

Studies III and IV included children with HI. The 14 children ( 3 male) were aged 4;06;8 $(M=5 ; 0)$. Criteria for inclusion were: Age four to six years, spoken Swedish as first language, mild to profound bilateral sensorineural HI, and full time use of HA or CI. Exclusion criteria were: Conductive HI, additional functional impairments besides the HI (such as the HI occurring as part of a syndrome), neurodevelopmental or psychiatric disorders, and multilingualism (including sign language). Background characteristics of the children with $\mathrm{HI}$ are displayed in table 4.

Nine children had bilateral HA, three had bilateral CI, and two had bimodal stimulation with one HA and one CI. The degree of HI ranged from mild to profound. 
Cause of hearing impairment was unknown for twelve children, inner ear malformation for one child, and suspected but unconfirmed congenital cytomegalovirus (CMV) infection for one child. The caregivers of all children reported that the HA and/or CI were used full time. All children were raised in hearing, Swedish-speaking families, and attended preschool integrated in a mainstream educational setting.

Letters with information about the study were distributed to caregivers of 103 children (70 with HA, 33 with CI), and 24 (11 HA, 13 CI) consented to participation. Out of these, ten were lost due to difficulties finding a suitable time for testing.

Table 4. Hearing background of the children with $\mathrm{HI}(\mathrm{n}=14)$.

\begin{tabular}{|c|c|c|c|c|c|c|c|}
\hline Child & $\begin{array}{c}\text { Unaided } \\
\text { PTA dB } \\
\text { BEHL }\end{array}$ & $\begin{array}{l}\text { Age at } \\
\text { testing }\end{array}$ & $\begin{array}{l}\text { Age } 1^{\text {st }} \text { CI } \\
\text { implanta- } \\
\text { tion }\end{array}$ & $\begin{array}{c}\text { Age activa- } \\
\text { tion } \\
1^{\text {st }} \mathrm{CI} \\
\end{array}$ & $\begin{array}{l}\text { Age } \\
2^{\text {nd }} \\
\text { CI } \\
\end{array}$ & $\begin{array}{l}\text { Age } 1^{\text {st }} \\
\text { HA } \\
\text { fitting }\end{array}$ & $\begin{array}{c}\text { Time since } 1^{\text {st }} \\
\mathrm{CI} / \mathrm{HA}\end{array}$ \\
\hline \multicolumn{8}{|c|}{ Bilateral CI } \\
\hline 01 & 85.0 & 68.2 & 9.6 & 10.2 & 29.7 & 3.2 & $58.0 / 65.0$ \\
\hline 02 & 103.0 & 48.5 & 20.5 & 21.3 & 32.5 & 16.0 & $27.2 / 32.5$ \\
\hline 03 & 102.0 & 48.4 & 15.0 & 15.9 & 22.7 & 3.0 & $32.5 / 45.4$ \\
\hline Mean & 97.0 & 55.0 & 15.0 & 15.8 & 28.3 & 7.4 & $39.2 / 47.6$ \\
\hline \multicolumn{8}{|c|}{ Bimodal CI+HA } \\
\hline 04 & 57.5 & 79.5 & 56.4 & 58.0 & - & 4.9 & $21.5 / 74.6$ \\
\hline 05 & 55.0 & 57.6 & 49.2 & 50.1 & - & 38.2 & $7.5 / 19.4$ \\
\hline Mean & 56.3 & 68.6 & 52.8 & 54.1 & & 21.6 & $14.5 / 47.0$ \\
\hline \multicolumn{8}{|c|}{ Bilateral HA } \\
\hline 06 & 46.0 & 64.0 & - & - & - & 55.9 & 8.1 \\
\hline 07 & 42.5 & 55.8 & - & - & - & 18.9 & 36.9 \\
\hline 08 & 64.5 & 58.7 & - & - & - & 49.3 & 9.4 \\
\hline 09 & 25.0 & 73.2 & - & - & - & 40.4 & 22.8 \\
\hline 10 & 30.0 & 50.0 & - & - & - & 29.0 & 20.9 \\
\hline 11 & 50.0 & 64.0 & - & - & - & 37.8 & 26.2 \\
\hline 12 & 55.0 & 48.3 & - & - & - & 4.1 & 44.2 \\
\hline 13 & 47.5 & 68.4 & - & - & - & 3.9 & 64.4 \\
\hline 14 & 52.5 & 59.3 & - & - & - & 12.4 & 47.0 \\
\hline Mean & 45.9 & 60.2 & & & & 28.0 & 31.1 \\
\hline$M d \mathrm{CI}$ & 102.0 & 48.5 & 15.0 & 15.9 & 30.7 & 3.2 & 32.5 \\
\hline$M d H A$ & 47.5 & 59.3 & & & & 29.0 & 26.2 \\
\hline
\end{tabular}

Notes: Ages are reported in months. HI = hearing impairment; PTA dB BEHL = pure tone average better ear hearing level in decibels; $\mathrm{CI}=$ cochlear implant; $\mathrm{HA}=$ hearing aid; $M d=$ median value.

\section{Children with typical language development}

Studies I, II, III and IV included children with TLD. In study I, 44 children (12 male) aged 4;0-5;11 $(M=4 ; 11)$ participated. Studies II, III and IV included 29 children (11 male), aged 4;1-6;8 ( $M=5 ; 1)$. Inclusion criteria were: Age four to six years, spoken Swedish as first language. Exclusion criteria were: Multilingualism, known or suspected neurodevelopmental or psychiatric disorders, hearing impairment or history of impaired hearing, e.g. due to recurrent otitis media with effusion. 
The children in study I were recruited as part of a master thesis project (Andersson \& Martikainen, 2013). Caregivers of 82 children received information about the study. Written consent was given for 52 children to participate, but eight were lost due to illness, unwillingness of the child to participate, suspected HI or DLD, or because they were too young. For recruitment for studies II-IV, information letters were distributed to the caregivers of 166 children. Written consent was obtained for 34 children, but the caregivers of five children later declined to participate prior to testing.

Table 5. Participants in each of the papers.

\begin{tabular}{lllllll}
\hline Group & Paper & $\mathrm{n}$ & Age & \multicolumn{3}{l}{ Gender } \\
\hline \multirow{2}{*}{ DLD } & II, IV & 30 & $4 ; 11$ & $4 ; 1-6 ; 2$ & $10 / 20$ & $66.7 \%$ \\
& & & & & & \\
HI & III, IV & 14 & $5 ; 0$ & $4 ; 0-6 ; 8$ & $11 / 3$ & $21.4 \%$ \\
& & & & & & \\
\multirow{2}{*}{ TLD } & I & 44 & $4 ; 11$ & $4 ; 0-5 ; 11$ & $32 / 12$ & $27.3 \%$ \\
& II-IV & 29 & $5 ; 1$ & $4 ; 1-6 ; 8$ & $18 / 11$ & $37.9 \%$ \\
\hline
\end{tabular}

Notes: Age is shown as years;months.

\section{Ethical considerations}

The PhD project studies received ethical approval from the Regional Ethical Review Board in Linköping, Sweden. There was no risk of physical harm associated with participation. The caregivers of all children received written information about the study, including that all participation was voluntary and that consent to participate could be withdrawn at any time without stating a reason. They were also given the opportunity to receive oral information and to ask any questions they had about e.g. the purpose of the study, participation, confidentiality or data handling. The caregivers were also offered to receive information about future publications that included data from their children. The children received simplified oral information prior to testing, and were given the opportunity to ask questions.

In order to inconvenience the children and their families as little as possible, they were given the choice of performing the testing at home, at a hospital clinic, or at Linköping University, whichever suited them best.

During the testing sessions, breaks were taken if the child expressed that they were tired, or for some other reason needed a pause. Light refreshments were available to the children and any accompanying adults or siblings. The children were not coerced into participating. Positive feedback and encouragement was given between the tests. 


\section{Data collection and analyses}

Two data collections were conducted for the $\mathrm{PhD}$ project. In the first (paper I), all children were tested at their respective preschool in single sessions lasting 45 to 60 minutes. In the second (papers II-IV), testing was conducted either in the homes of the children, at their regular SLP or audiology clinic, at their preschool, or at Linköping University. Testing typically lasted between 90 and 120 minutes, and was carried out in one or two sessions.

\section{Paper I}

Beside the main WR and NWR task and the Phoneme Test (Hellqvist, 1995; see below), tests of language comprehension (SIT; Hellqvist, 1989), phonology and grammar (Nya Lundamaterialet; Holmberg \& Stenkvist, 1983), and nonverbal cognitive ability (Raven's matrices; Raven, Raven, \& Court, 1998). As these measures were only treated as pretesting measures to assess typical development in paper I, they will not be described in detail here.

\section{Papers II, III and IV}

\section{Word and nonword repetition}

A word and nonword repetition task (table 6) was constructed whose purpose was to enable analyses of prosodic features. The task consisted of 25 words and 25 nonwords, matched pairwise for stress pattern and tonal word accent. Each possible combination of stress pattern and tonal word accent in Swedish one- to five-syllable words was represented, resulting in one monosyllabic item, three two-syllable items, five three-syllable items, seven four-syllable items, and nine five-syllable items. The words and nonwords in each pair were not matched for phonological complexity, but the total complexity was similar. The words contained 216 segments $(121$ consonants and 95 vowels), and 22 consonant clusters ( 3 initial and 19 medial). The nonwords contained 212 segments (117 consonants and 95 vowels), and 18 clusters ( 3 initial and 15 medial). 
Table 6. Features of the words and nonwords in the repetition task.

\begin{tabular}{|c|c|c|c|c|}
\hline $\begin{array}{l}\text { No. of } \\
\text { syllables }\end{array}$ & $\begin{array}{l}\text { Stress } \\
\text { pattern }\end{array}$ & $\begin{array}{l}\text { Tonal } \\
\text { word } \\
\text { accent }\end{array}$ & Word (translation) & Nonword \\
\hline 1 & S & 1 & já:n (male name "Jan") & já:b \\
\hline 2 & WS & 1 & kanín (rabbit) & Ifứ:m \\
\hline 2 & SW & 1 & pá:trık (male name "Patrik") & dá:tri \\
\hline 2 & SW & 2 & værrm $\varepsilon$ (heat) & mìrve \\
\hline 3 & WWS & 1 & spesıél (special) & reveél \\
\hline 3 & WSW & 1 & kristófer (male name "Kristoffer") & kratékel \\
\hline 3 & SWNW & 1 & mí:nimem (minimum) & káisımem \\
\hline 3 & WSW & 2 & sesàna (female name "Susanna") & pelàmna \\
\hline 3 & SWW & 2 & blùmkrtzka (flower pot) & hø̀ntpษ:le \\
\hline 4 & WWWS & 1 & Eventeél (possible) & getenımflǽ:r \\
\hline 4 & WSWW & 1 & histú:ria (story) & hydó:rra \\
\hline 4 & WWSW & 1 & karaméler (bonbons) & dralabélı \\
\hline 4 & SWWW & 1 & kómpisana (friends) & knámtıgavas \\
\hline 4 & SWWW & 2 & ìnebandy (floorball) & àtefnษ:VI \\
\hline 4 & WWSW & 2 & jemnastìkssa:l (gymnasium) & tıbefì:me \\
\hline 4 & WSWW & 2 & kanè:lbele (cinnamon bun) & ganù:lmelte \\
\hline 5 & WWWSW & 1 & tyranusāures (tyrannosaurus) & laritobó:nis \\
\hline 5 & SWWWW & 1 & téletabisar (teletubbies) & déletamesar \\
\hline 5 & WSWWW & 1 & Irá:niena (iranians) & elý:migeta \\
\hline 5 & WWSWW & 1 & dinusāurie (dinosaur) & tisudá:riu \\
\hline 5 & WWWWS & 1 & elektrisité:t (electricity) & amitrusukí:l \\
\hline 5 & WWSWW & 2 & berjudà:lba:na (roller coaster) & bærkatỳ:lpa:na \\
\hline 5 & SWWWW & 2 & ìsshokykleba (ice hockey stick) & ì:gotcklena \\
\hline 5 & WSWWW & 2 & firàffø:tare (giraffe keeper) & filàtfo:lare \\
\hline 5 & WWWSW & 2 & pomperipòsa (a witch from a fairy tale) & bamperınèfa \\
\hline
\end{tabular}

Notes: $\mathrm{S}=$ strong, stressed syllable; $\mathrm{W}=$ weak, unstressed syllable. Some items have been adopted from Sahlén et al. (1999).

The words included in the task were, as far as possible, selected to be familiar to children aged four and above. The nonwords were selected based on a list of 131 nonwords conforming to Swedish phonotactics. These were mostly newly constructed nonwords, but some had been used in previous studies of NWR. Each nonword was judged as either sounding like a word, or not sounding like a word, by 8 adult naïve raters. The total wordlikeness score for each non-word ranged from 0 to 8 , and non-words with the lowest wordlikeness score in each prosodic condition (length, stress pattern and tonal word accent in combination) were included in the repetition task.

The word and nonword stimuli were recorded by a female speaker with a Central Swedish accent. In the testing session, the task was administered using a computer program (Brehmer, 2014), which randomized the presentation order and played back 
the stimuli. Each child started with either the words or the nonwords. The stimuli were presented to the children in free field via loudspeakers at approximately $70 \mathrm{~dB}$ SPL. Before commencing, the children were told that they were going to hear some real words or words that were made up, and that they should imitate them as well as they could. Stimuli that the child did not attempt to repeat were excluded from the analyses. The children's responses were audio recorded and transcribed phonetically.

Scoring of the task was done by comparing the transcriptions of the children's productions to a transcription of the stimuli as pronounced by the female speaker on the recordings. For segmentals (consonants and vowels), each speech sound was scored as correct or incorrect. Allophonic variants of phonemes were accepted (e.g. [I] instead of [r]), as were minor non-phonemic articulatory deviations (e.g. [s] instead of [s]). Three main measures were obtained: percentage of consonants correct (PCC), percentage of vowels correct (PVC), and percentage of phonemes correct (PPC; consonants and vowels combined). The formula used was $P C C, P V C, P P C=\frac{\text { Number of correct sounds }}{\text { Number of } c \text { correct Plus sncorrect sounds }} \times 100$ (Shriberg \& Kwiatkowski, 1982). PCC, PVC and PPC were calculated for the total of all words or nonwords, for each length condition (1-5 syllables), and for each tonal word accent condition (tonal word accent 1 or 2).

Prosodic features (stress and tonal word accent) were scored as correct or incorrect. Stress was scored as incorrect if stress placement was on the wrong syllable, if more than one syllable received stress, or if any syllables were added or omitted. A syllable was counted as omitted if the vowel was lost. When consonants in a syllable, but not the vowel, were retained, these were considered to coalesce with surrounding syllables following the maximum onset principle. Tonal word accent was scored as incorrect if it was the wrong variant (e.g. 1 instead of 2), if it could not be classified as either 1 or 2 , or if there were more than one tonal word accent. For both stress and tonal word accents, the total percentage of correct productions in words and nonwords was calculated. Percentages were also calculated for each length condition with several syllables (2-5 syllables).

\section{Phonology}

The short version of the Phoneme Test (Hellqvist, 1995) was used to assess phonological production. The test includes 72 pictures corresponding to child-appropriate words that give an overview of the child's phoneme inventory. Most phonemes and the most common consonant clusters in Swedish are represented in different word positions. The targets as intended are 32 one-syllable words, 32 two-syllable words, seven three-syllable words, and one five-syllable word. There is a variation in stress patterns, but penultimate stress is the most frequent in the words that have more than one syllable. All monosyllables have tonal word accent 1, and out of the multisyllabic 
words, 13 have tonal word accent 1, and 27 have tonal word accent 2. All responses were accepted, even when they differed lexically from the words originally intended in the test (e.g. saying klänning 'dress' instead of kjol 'skirt'). Words that the children did not attempt were not included in the analyses. All responses were audiorecorded and transcribed phonetically. Scoring was based on comparisons between the children's pronunciation and the adult pronunciation of the target word intended by the child. PCC, PVC and PPC, and percentages of stress and tonal word accents correct, were calculated.

\section{Grammar}

Grammatical production was assessed with Gramba (Hansson \& Nettelbladt, 2004). In this test, Swedish verb morphology, nominal morphology, and syntax are targeted using sentence continuation and completion. The maximum total score is 44 points, divided between verbal morphology (15 p), nominal morphology (19 p), and syntax $(10 \mathrm{p})$. For the purpose of detailed analyses of grammatical production in paper IV, the scores on each of 14 subcomponents were analyzed (table 7).

\begin{tabular}{|c|c|c|c|c|}
\hline & $\begin{array}{l}\text { Max } \\
\text { score }\end{array}$ & Target structures & Example & Translation \\
\hline Verbal morphology & 15 & & & \\
\hline Present tense & 3 & Verb stem + suffix (-er) & köp-er & buys \\
\hline Past tense preterite & 3 & Verb stem + suffix (-te) & köp-te & bought \\
\hline Future tense & 3 & Auxiliary verb + infinite verb & ska köpa & will buy \\
\hline Past tense perfect & 3 & Auxiliary verb + supine verb & har köpt & has bought \\
\hline Copula & 3 & Copula verb & är & is \\
\hline Nominal morphology & 19 & & & \\
\hline Plural & 3 & Noun stem + suffix (-ar/-er/-or) & katt-er & cats \\
\hline Indefinite article & 3 & Article $(e n / e t t)+$ noun & en katt & a cat \\
\hline Definite form & 3 & Noun stem + suffix $(-e n /-e t)$ & katt-en & the cat \\
\hline Noun phrase agreement & 4 & Article + adjective + noun & den stora katten & the big cat \\
\hline Genitive case & 3 & $\begin{array}{l}\text { Noun stem }+ \text { definite form suffix }+ \text { genitive suf- } \\
\text { fix }(-s)\end{array}$ & katt-en-s & the cat's \\
\hline $\begin{array}{l}\text { Adjective predicative agree- } \\
\text { ment }\end{array}$ & 3 & Subject + copula + adjective & katten är gul & $\begin{array}{l}\text { the cat is yel- } \\
\text { low }\end{array}$ \\
\hline Syntax & 10 & & & \\
\hline Negation placement & 3 & Auxiliary verb + negation + infinite verb & kan inte hoppa & cannot jump \\
\hline Relative clause & 3 & Relative pronoun + verb & som äter & who eats \\
\hline Topicalization & 4 & Topicalized word + verb + subject & sen sover de & then they sleep \\
\hline Total max score & 44 & & & \\
\hline
\end{tabular}

\section{Vocabulary}

Receptive vocabulary was assessed with The Peabody Picture Vocabulary Test, Third Edition (PPVT-III; Dunn \& Dunn, 1997), adapted to Swedish by (Fyrberg, Gustavsson, \& Lundälv, 2001). The test includes a total of 202 items divided into 17 sets. Answers are given by the child by pointing to the one picture out of four which 
best matches the word spoken by the examiner. The norms for PPVT in Swedish are lacking, and therefore only the raw scores were used in the present thesis.

\section{Orofacial function}

Orofacial function was assessed with the examination part of the Nordic Orofacial Test-Screening (NOT-S; Bakke et al., 2007), which is divided into six main areas, with one to four subtasks: (1) face at rest, (2) nose breathing, (3) facial expression, (4) masticatory muscle and jaw function, (5) oral motor function, and (6) speech. The maximum total score is 6 ( 1 for each area). Subtask 6C "Say pataka, pataka, pataka" was excluded, since it is not used with children under five years of age.

\section{Nonverbal cognitive ability}

The block design subtest from Wechsler Preschool and Primary Scale of Intelligence, Third Edition (WPPSI-III; Wechsler, 2005) was used to assess nonverbal ability. No verbal responses are required, and the task is to replicate a pattern of one- or twocolored blocks within a given time limit. The patterns are presented either as models constructed by the examiner, or as pictures.

\begin{tabular}{|c|c|c|c|c|c|}
\hline Ability & Test & Paper I & Paper II & Paper III & Paper IV \\
\hline WR & WR task & $\checkmark$ & $\checkmark$ & & $\checkmark$ \\
\hline NWR & NWR task & $\checkmark$ & $\checkmark$ & $\checkmark$ & $\checkmark$ \\
\hline Phonological production & Phoneme test & $\checkmark$ & $\checkmark$ & $\checkmark$ & $\checkmark$ \\
\hline Grammatical production & Gramba & & $\checkmark$ & $\checkmark$ & $\checkmark$ \\
\hline Receptive vocabulary & PPVT & & $\checkmark$ & $\checkmark$ & $\checkmark$ \\
\hline Orofacial function & NOT-S & & $\checkmark$ & $\checkmark$ & $\checkmark$ \\
\hline
\end{tabular}

\section{Statistical analyses}

\section{Paper I}

In paper I, mixed repeated-measures analysis of variance (ANOVA) was used to examine:

- The effects of the between-groups factor age (2 levels: younger or older group), and the within-group factors stimulus type (2 levels: word or nonword), tonal word accent (two levels: 1 or 2 ) and segment type (2 levels: consonant or vowel) on segment repetition accuracy (PCC and PVC). 
- The effects of the between-groups factor age (2 levels: younger or older group), and the within-group factors stimulus type (2 levels: word or nonword), length (4 levels: 2, 3, 4 or 5 syllables) and tonal word accent (two levels: 1 or 2) on phoneme repetition accuracy (PPC).

- The effects of the between-groups factor age (2 levels: younger or older group), and the within-group factors stimulus type (2 levels: word or nonword) and phonological level (2 levels: prosodic composite or segments) on repetition accuracy.

Follow-up analyses were conducted using Bonferroni-adjusted post hoc pairwise comparisons.

For the purpose of obtaining a prosodic composite measure, correlations between the prosodic measures were examined with Kendall's tau correlations. As the children with TLD in paper I performed near ceiling on some measures, arcsine square-root transformations of the data were conducted.

\section{Paper II}

In paper II, group differences between the children with DLD and TLD on background and language measures were analyzed with independent samples $t$-tests. Performance on the repetition task was analyzed with mixed repeated measures ANOVA, with stimulus type (2 levels: word or nonword) and length (4 levels: 2, 3, 4 or 5 syllables) as within-groups factors, and group (2 levels: DLD or TLD) as between-groups factor. Like in paper I, follow-up analyses were conducted using Bonferroni-adjusted post hoc pairwise comparisons.

Error type frequencies were examined with Mann-Whitney U tests for betweengroup analyses, and with Wilcoxon signed-rank test for within-group analyses. The reason for using nonparametric tests was that near ceiling effects (i.e. a low number of errors) were evident for the children with TLD.

Pearson product-moment correlations were calculated to examine the possible relationships of stress and tonal word accent repetition to phonological production (PPC), grammatical production, and receptive vocabulary. The false discovery rate was corrected using the Benjamini-Hochberg procedure (Benjamini \& Hochberg, 1995). 


\section{Paper III}

Mann-Whitney U tests were used for between-group comparisons of NWR, language and background measures. For within-group comparisons of consonant and vowel repetition, and prestressed and poststressed syllable omissions, Wilcoxon's signed rank test was used. Friedman's ANOVA was used for within-group comparisons of repetition performance between the different length conditions (2, 3, 4 and 5 syllables). Kendall's tau correlations were used to explore possible relationships between NWR, language, and background variables. To account for multiple comparisons, the false discovery rate was controlled using the Benjamini-Hochberg procedure (Benjamini \& Hochberg, 1995).

\section{Paper IV}

Comparisons between the three groups (DLD, HI and TLD) were made using Kruskal-Wallis tests on the phonological and grammatical production measures, age, nonverbal cognitive ability, and maternal education. Significant main effects were followed up using pairwise comparisons with adjusted $p$-values, with an overall $a$-level of 0.05 . 


\section{SUMMARY OF THE PAPERS}

In the following section, the findings of each of the individual papers are summarized. The papers can be found at the end of the thesis, and the reader is referred to them for more details.

\section{Paper I}

This study was conducted in order to evaluate the performance of children with TLD on the word and nonword repetition task. The first aim was to investigate the effect of age on repetition performance. To this end, the participants $(n=44)$, were divided into two age bands, 4;0-4;11 $(n=20)$ and 5;0-5;11 $(n=24)$. As phonological development is still under way between the ages of four and six, it was expected that repetition accuracy would be higher in the five-year-olds than in the four-year-olds. The second aim was to examine if the prosodic properties of words and nonwords influence repetition of consonants and vowels, i.e. phonological production at the segmental level. Repetition accuracy was expected to decrease with an increasing number of syllables, and it was also hypothesized that consonants and vowels would be more accurately repeated in words or nonwords with tonal word accent 2 compared to tonal word accent 1.

Words were easier to repeat than nonwords, but only when segment repetition, i.e. repetition of consonants and vowels, was considered. Worthy of note is that the children in this study repeated tonal word accents very accurately in both words and nonwords. Accuracy for prosodic features did not differ between words and nonwords, which could indicate that prosodic representations are more stable than segment representations. In line with this, prosodic features were more accurately repeated than segments. Another finding was that repetition performance was higher for vowels than for consonants, a difference that was larger in nonwords compared to words, which suggests that familiarity with the repetition stimuli is more important for consonants.

In line with the predictions, the older children achieved higher results overall on both WR and NWR, indicating that the ability to repeat both prosodic and segmental features improves from four to six years of age in children with TLD. Some support was also found for an influence of prosody on segment repetition. Consonants and vowels in longer items were harder to repeat, but there was no linear relationship between the number of syllables and segment repetition accuracy, suggesting that factors other than length, including prosodic features, are important. The length effect 
differed both between words and nonwords, and between the tonal word accent conditions. Further, the two tonal word accents appeared to have provided different conditions for segment repetition; in general, segments in words and nonwords with tonal word accent 2 were easier to repeat compared to segments in tonal word accent 1 words and nonwords.

An implication of potential clinical importance is that both rhythmical (stress) and tonal (tonal word accent) properties should be taken into account when constructing or using NWR tasks. The length effect is often put in relation to phonological working memory capacity: long nonwords tax phonological working memory more. However, the finding that different prosodic properties provided different conditions for segment repetition in this study could indicate that differences between shorter and longer words or nonwords also reflect prosodic ability.

\section{Paper II}

Repetition of prosodic word and nonword features was further investigated in the second study, which included both children with typical and atypical language development. The WR and NWR task was the same as in paper I, but a different group of children with TLD was included. The main purpose of this study was to examine if Swedish-speaking children with DLD repeat stress and tonal word accent in words and nonwords as accurately as children with TLD. Problems with word level prosody are prevalent in children with DLD acquiring Swedish as their first language. Further, studies of English-speaking children have shown that children with DLD are less able to repeat stress patterns compared to children with TLD. In the light of these previous findings, the hypothesis about the outcomes in this study was that the children with DLD would exhibit a lower ability to repeat stress and tonal word accent.

Consistent with the hypothesis, the results showed that the children with DLD repeated stress and tonal word accent in both words and nonwords less accurately than the children with TLD. The group difference for tonal word accent repetition was not dependent on the length of the stimuli, i.e. the children with DLD achieved lower scores on short and long items alike. With regard to repetition of stress, there was no difference between the groups for two- and three-syllable items, while the children with DLD performed below the TLD children on the longer four- and fivesyllable items. The majority of stress errors were related to the omission of unstressed syllables, especially in prestressed position. The children with DLD omitted significantly more unstressed syllables in prestressed positions (occurring before the stressed syllable of the word or nonwords) than in poststressed positions (after the stressed syllable) in both words and nonwords. A difference between prestress and 
poststress syllable omissions was found also for the children with TLD, but only in WR. This indicates that differences between children with DLD and TLD regarding the ability to repeat prosodic nonwords features are qualitative as well as quantitative.

A secondary purpose was to explore potential correlations between the ability to repeat prosodic word or nonwords features and language ability. Measures of phonological production (The Phoneme Test), expressive grammar (Gramba) and receptive vocabulary (PPVT-III) were included to enable fulfillment of this purpose. Given the dearth of previous research, no specific hypotheses were stated.

The results of the correlational analyses did not show that the ability to repeat stress and tonal word accent is related to phonological production during naming of familiar pictures, or to receptive vocabulary. The only significant correlation found was between stress repetition in words and expressive grammar. Although this result needs replicating, it could indicate that repetition of stress and the use of grammatical morphemes share some common underlying factor, which might be related to prosodic ability.

The findings of this study adds to the body of research that has shown that there are differences in WR and NWR ability between children with DLD and children with TLD. For the first time, this was found also for repetition of tonal word accent in Swedish.

\section{Paper III}

The third study included in this thesis included children with HI and children with TLD, and took a methodological approach similar to that in paper II. The first aim was to investigate both prosodic and segmental aspects of NWR in children with bilateral mild to profound sensorineural HI, compared to age-matched controls with TLD. The study employed the same WR and NWR task, but the WR part was excluded in the analyses. The second aim was to examine potential correlations of NWR performance in children with HI to language, degree of HI, nonverbal cognitive ability, and maternal education. The language measures included were The Phoneme Test, Gramba and PPVT-III. Nonverbal cognitive ability was measured with the block design subtest of WPPSI-III.

Both prosodic features (stress and tonal word accent), and segments were repeated less accurately by the children with HI compared to the children with TLD. However, no difference in tonal word accent repetition accuracy between the groups was found in two-syllable nonwords. The findings that repetition of stress and segments is challenging for children with $\mathrm{HI}$ are in line with previous studies of older Swedish-speaking children who use CI or HA. Tonal word accent in nonwords have, 
to the best of the authors knowledge, not been studied in this population before. Tonal word accent errors made by the children were mainly substitutions of one tonal word accent for the other, and not a lack of a clearly distinguishable tonal word accent altogether. The results indicated that tonal word accent 1 was easier to repeat than tonal word accent 2 . In contrast, Swedish-speaking children with TLD generally acquire tonal word accent 2 first, and Swedish-speaking children with DLD often substitute tonal word accent 1 with tonal word accent 2 .

Significant correlations were found between NWR and PPC in the Phoneme test, expressive grammar, and receptive vocabulary. There was also a significant correlation of NWR to unaided hearing level. While the sample of children of children with HI was small and heterogeneous, this finding indicates that NWR has potential as a useful tool to identify children with HI who, regardless of what hearing assistive technology they use, are in need of speech and language intervention.

\section{Paper IV}

Children with DLD have unexplained language deficits, and children with any degree of HI are at an increased risk of speech and language problems. These two groups of children develop language under different conditions, and their language difficulties may or may not be similar. Moreover, it is not clear whether language development in children with DLD or HI is best described as typical but delayed, or if it follows a trajectory that deviates from that of children with TLD. The purpose of this study was to explore similarities and differences in phonological and grammatical production between the groups of children with DLD, HI, and TLD.

The groups were compared on measures of phonological production during picture naming (The Phoneme Test) and word and nonword repetition (the WR and NWR task), and on the expressive grammar test (Gramba). The results showed that the groups differed significantly on production of consonants, vowels, stress patterns, and tonal word accents, in both the picture naming task, and in the WR and NWR task. The pairwise comparisons between the groups revealed a similar pattern for most measures: the children with DLD and HI performed below the children with TLD, but they did not differ from each other. The only exception was tonal word accents in WR, which were more accurately repeated by the children with DLD compared to the children with HI.

Detailed analyses of the results on the Gramba showed less consistency concerning the overall group differences, but the children with TLD still outperformed the children with DLD and HI on most subtasks. No difference between the groups was 
found for the use of present or future tense, plural, negation placement, or topicalization word order. Few significant group differences could be revealed between the children with DLD and HI. The only exception was the noun predicative agreement subtask, on which the children with DLD achieved higher results.

To summarize, children with DLD and HI demonstrated comparable levels of performance on phonological and grammatical production, but the findings need replication with larger samples. Future quantitative studies may enable identification of uniquely characteristic strengths and weaknesses in children with DLD and HI respectively. Based on the present findings, syntactic ability may be a strength in both groups. Thus, intervention strategies harnessing syntactic ability, e.g. syntactic bootstrapping, could be beneficial in therapy targeting speech sound production, grammar, or word learning. 


\section{DISCUSSION}

The first general research question was concerned with the characteristics of prosodic and phonological production during WR and NWR in children with DLD and HI. The results of studies II, III and IV showed that both clinical groups achieved lower levels of performance on the repetition of consonants, vowels and stress compared to the group of children with TLD. These findings were expected from previous studies of Swedish-speaking children with DLD and HI (Ibertsson et al., 2008; Nakeva von Mentzer et al., 2015; Sahlén, Reuterskiöld-Wagner, Nettelbladt, \& Radeborg, 1999). The findings of the present thesis also contribute new information about tonal word accent repetition. In comparison to segments and stress, tonal word accents were repeated with higher accuracy by the children with DLD and HI, but performance was still lower than for the children with TLD. The results of study IV showed that performance on tonal word accent repetition was lower in the children with HI than in the children with DLD, but the difference between the groups was only significant for WR.

Tonal word accents are realized on syllables with primary stress, but have distinct tonal patterns that span over whole words (or rather phonological words). While they must be timed in relation to the stressed syllable, they have longer duration than segments and syllables, which could explain why they were repeated with more ease by the children with DLD and HI. Problems with phonological units of short duration have been attested in both DLD (Leonard et al., 1992) and HI (Svirsky, Stallings, Lento, Ying, \& Leonard, 2002). The lower scores achieved by the children with HI could be explained by both reduced general hearing levels, and by the restricted possibility to detect frequency modulations (Moore, 2007). However, it should be noted that most tonal word accent errors in WR and NWR were judged as substitutions of one tonal word accent for the other. Thus, the problem was seldom that children in either the DLD or HI group used an indistinct or deviant tonal pattern. Given the finding that the children with HI repeated tonal word accent 1 more accurately than tonal word accent 2 , it is possible that some of the children used tonal word accent 1 by default. This would appear to be in line with the assumption that tonal word accent 1 is the unmarked variant, assigned by default in the absence of lexical specification for tonal word accent 2 (Riad, 2014, but see also Bruce, 1977, and Lahiri et al., 2005, for alternative accounts). On the other hand, an advantage for tonal word accent 1 in children is surprising given that tonal word accent 2 is acquired first (Peters \& Strömqvist, 1996). The children with DLD repeated tonal word accent 1 more accu- 
rately than tonal word accent 2 in nonwords, but not in words, which could also suggest that tonal word accent 1 is used more when there are no lexical representations available. It is worthy of note that there are relatively few studies of tonal word accent development in typically developing children, as well as in children with atypical language development. Further research is needed to explain why it would be the case that children with DLD and HI find it easier to use tonal word accent 1 , if tonal word accent 2 is indeed acquired first by children with TLD.

Regarding the repetition of stress patterns, both children with DLD and children with HI omitted significantly more unstressed syllables than the children with TLD. In both groups, there was also a clear effect of prosodic position; significantly more unstressed syllables were omitted in prestressed positions, i.e. when they occurred before the stressed syllable, compared to poststressed positions (after the stressed syllable). The reason for this is unlikely to be differences in duration or amplitude between prestressed and poststressed syllables, although this was not confirmed. Instead, it suggests a trochaic bias effect, building on the assumption that children demonstrate a preference for the dominant stress pattern in the ambient language, and therefore omit syllables that fall outside of this pattern (Gerken, 1991, 1994). This effect has been found previously in Swedish-speaking children with DLD and HI (Nakeva von Mentzer et al., 2015; Sahlén et al., 1999). The present findings indicated that the size of this effect was comparable in the groups with DLD and HI, with about twice as many prestress syllable omissions as opposed to poststress syllable omissions. The children with TLD omitted twice as many prestressed compared to poststressed syllables in nonwords, while there was no difference in words, suggesting that the effect of prosodic position was not as strong in the TLD group. A trochaic bias is normally found in younger children with TLD, but the present findings cannot tell us if performance in the children with DLD and HI is similar to that of younger typically developing children.

Compared to the children with TLD, the children with DLD and HI repeated consonants and vowels with less accuracy, but the latter two groups did not differ significantly from each other on either PCC or PVC in words and nonwords. Further, consonants were more difficult to repeat than vowels in all groups. A HI presumably has detrimental effects on the ability to perceive and use segments, especially consonants, resulting in deviant or delayed development compared to children with TLD and normal hearing, although many children catch up after receiving CI or HA (Faes et al., 2016; Moeller et al., 2010). The difficulties with segment repetition in the children with DLD are not attributable to reduced hearing acuity, but rather to problems in phonological processing of a more cognitive or linguistic origin. So, while performance was similar in the clinical groups, their problems might be caused by different 
underlying factors. The increased risk of phonological problems associated with HI can be hypothesized to lead to a double deficit in repetition tasks, since the demands on both accurate hearing and phonological processing are high. This would, at the group level, presumably put them at a greater disadvantage than children with DLD. If this is indeed the case, it was not evident from the findings of the present thesis. In study IV, tonal word accent repetition in words was the only repetition measure on which the DLD children achieved significantly higher performance compared to the children with HI. Although the mean scores for vowel and stress repetition in both WR and NWR were also higher in the DLD children, the difference compared to the HI children did not reach significance.

In summary, production of both segments (consonants and vowels) and prosody (stress and tonal word accent) in WR and NWR in children with DLD and children with HI was characterized by lower levels of accuracy compared to children with TLD. Consonants were most problematic, while tonal word accents were repeated relatively successfully. In relation to prosodic production, tonal word accent 1 and unstressed syllable occurring in a trochaic stress pattern appeared to benefit repetition performance in both children with DLD and HI. Finally, few differences could be found between the children with DLD and the children with HI.

An interest in the potential relationship between the ability to repeat prosodic word and nonwords features and language ability, spurred the second general research question. Prosodic ability has been proposed to play an important role in the acquisition of lexical, grammatical and phonological elements, for example by providing cues to word and phrase boundaries, and by highlighting important information (Arbisi-Kelm $\&$ Beckman, 2009). However, such proposals are only remotely suggestive of a relationship between the ability to repeat prosodic features in word or nonwords, and more general language ability. In this thesis, investigations into how the ability to repeat prosodic features of words and nonwords might possibly be related to language ability were undertaken in studies II and III. Correlational analyses in study II did not provide support for a relationship in children with DLD between repetition of either stress or tonal word accent and segmental production (PPC) in picture naming (The Phoneme Test), or receptive vocabulary (PPVT). There was, however, a significant medium correlation between repetition of stress in words and expressive grammar (Gramba). In contrast, the results of study III showed that repetition of both stress and tonal word accents in nonwords was significantly correlated with the results on all language measures (The Phoneme Test, Gramba, and PPVT) in the children with HI. Further, significant correlations were found between unaided hearing level (dB 
BEHL) and repetition of stress and tonal word accent, but not between hearing level and the language measures.

Starting with the finding that the ability to repeat stress was related to expressive grammar in both the children with DLD and HI, there seems to be some support for a link between prosody and grammar. Theoretical accounts of grammatical morphology as partly prosodically conditioned state that certain morphemes are more difficult to acquire and use because of the prosodic positions they occur in (Demuth, 2014; Gerken, 1994, 1996). For example, many grammatical morphemes comprise unstressed syllables that occur outside of the typical trochaic stress pattern. In Swedish, this applies to e.g. articles, prepositions, and copulas. Most stress repetition errors made by the children with DLD and HI were omissions of unstressed syllables, mainly in prestressed positions (i.e. outside the trochaic pattern), and it is possible that there is a common underlying explanation for such omissions and difficulties with the use of grammatical morphemes.

The correlations found between repetition of prosody and language in the children with $\mathrm{HI}$ indicate that the ability to repeat stress and tonal word accent could be related to more general language knowledge. This is in line with results from Englishspeaking children with CI demonstrating that repetition of stress is correlated with receptive vocabulary, morphology and syntax, as well as with intelligibility (Carter et al., 2002). A possible explanation for the supposed relationship between NWR and language performance is that the ability to repeat prosodic patterns reflect memory and processing skills that are important to the acquisition of several receptive and expressive language skills. It has been proposed that the association between NWR and expressive language may be a result of a common underlying ability to process phonological information in the absence of support from long-term knowledge (Adams \& Gathercole, 1996).

To summarize, the results presented in this thesis suggested some associations between the ability to repeat prosodic word or nonword features and language ability. In the children with DLD, this was shown by the finding that children who exhibited high performance on stress repetition in words tended to have higher scores on the expressive grammar test. In the children with HI, the children who achieved higher scores on stress and tonal word accent repetition in nonwords generally obtained higher scores on the language tests. Further research is needed to confirm the presence of an association of prosodic repetition to language ability in children with DLD and $\mathrm{HI}$, and what the nature of such an association could be.

The third general research question concerned similarities and differences between children with DLD, children with HI, and children with TLD, regarding phonological 
production and expressive grammar. This was mainly examined in paper IV. With a few exceptions, the general pattern of results for phonological and grammatical production alike, was that both children with DLD and children with HI performed similar to each other, but below the level of the children with TLD. Regarding phonology, the ability to use tonal word accent was a relative strength for children with DLD and HI, both in the Phoneme Test, and in WR and NWR. Most notably no difference between the three groups was found for tonal word accent in production of familiar words in the Phoneme Test, suggesting that the ability to use this prosodic feature may be well preserved, despite problems with stress or segments. The children with HI performed below the DLD and TLD children on tonal word accent production in WR. This indicates that tonal word accent use in known words that need to be listened to, processed and articulated in a short amount of time is harder for children with HI. A possible explanation is that tonal word accent representations as part of lexical representations are less specified in children with HI compared to children with DLD and TLD.

While both the children with DLD and HI performed below the children with TLD on most nominal and verbal morphology subtasks of Gramba, syntax emerged as an area of strength. For placement of negations, and word order in topicalization, no difference between the groups was found. High results on these subtasks could be accomplished without highly accurate phonological production, which may have contributed to high results also in children with expressive phonological problems. The only grammar task for which a difference was found between DLD and HI groups was predicative agreement, with lower scores obtained by the HI children. The task required that the children accurately perceived and remembered the model construction presented by the examiner, and produced a subject noun, a copula comprising a prestressed syllable, and a predicative in agreement with the noun. The accumulated demands on grammatical ability, use of morphemes in prosodically disadvantaged positions, and phonological working memory, might have caused lower performance in the HI group. 


\section{Clinical implications}

Although the work with the present thesis has been exploratory, and many of the results obtained are suggestive rather than conclusive, there are some clinical implications.

Problems with the repetition of stress patterns in words might be indicative of problems with expressive grammar in children with DLD. The ability to repeat stress patterns could also be predictive of problems with receptive vocabulary, expressive grammar, and phonological production in children with HI. The binary scoring of stress as correct or incorrect used in the calculations of the total percentage score for WR and NWR is straightforward and quick. It is substantially faster to do than calculations of e.g. PCC, and does not appear to come with the risk of floor effects that may be associated with whole-word binary scoring in children with expressive phonological problems. However, much further work is needed before assessment materials such as the WR and NWR task can come into clinical practice. As an alternative, analyses of prosodic features could be performed as a complement in repetition tasks that are already in use.

The results of studies I-III indicated that prosodic factors are important for repetition performance, e.g. the choice of tonal word accent and the metrical properties used of the repetition stimuli. As prosody appears to have some influence on the outcome measures, regardless of if they are segmental or prosodic, the prosodic features of items included in repetition tasks should be taken into account. This is relevant in relation to the view that NWR is a measure of phonological working memory. Most established tests of NWR are scored based on whole-item or segment repetition. Seeing as some prosodic features may provide better conditions for repetition than others, part of what is typically interpreted as phonological working memory capacity may in fact reflect the child's prosodic ability.

Knowledge about which lexical prosodic features are harder or easier to use by children with language disorders could be utilized in therapy aimed at learning speech sounds, morphology or vocabulary. The results of this thesis indicate that trochaic stress patterns, and possibly tonal word accent 1 , could enhance production in children with DLD and HI. As treatment of phonology is often carried out at the word level, treatment of particularly difficult speech sounds could benefit from the use of these structure. The same line of reasoning could apply also to morphological intervention. Further, vocabulary acquisition could be facilitated if treatment target words are chosen with prosodic features in mind, or by encouraging the child to attend to the prosody of the words. 
Assessment of child phonology is often based on single word utterances, for instance made in the context of picture naming tasks similar to the Phoneme Test used in this thesis. Nonlinear approaches to phonological analysis acknowledge the importance of prosodic context for speech sound production, for example the word or syllable position a particular speech sound occurs in. The prominence of syllables, mainly determined by stress and tonal word accent in Swedish, likely affects production at the segmental level. Subsequently, descriptions of the phonological organization in a child should be based on assessment materials that include words which represent the lexical prosodic variation of the language.

\section{Methodological considerations}

The purpose of the present thesis was to explore prosodic and phonological ability in children with DLD and children with HI. However, the scope of the investigations has been quite limited.

First, the studies have only incorporated lexical prosody and phonology, leaving out e.g. phrase level and interactional aspects of prosody. In consequence, many of the skills that are part of 'prosodic and phonological ability' have found no place in this thesis.

Second, the measures of prosody and phonology has been almost exclusively production oriented, meaning that phonological perception is unaccounted for. In a complex task like NWR, perception is undoubtedly involved, but looking at production alone does not permit analyses of the degree to which variations in perception affect the outcomes.

Third, it could be argued that the quantitative approach taken in the majority of analyses in this thesis belies the complexity of phonology. While a measure such as PCC can tell us that a child appears to have problems using consonants, it does not provide information about which phonological features are problematic, or in which phonological contexts certain consonants are hard to produce. More qualitative investigations into the phonological organization, or the use of e.g. phonological processes, in children with DLD and HI would enable more detailed analyses of how the prosodic and phonological ability differs between these groups.

Fourth, data collection has been restricted to testing in a controlled situation, with structured interaction between the examiner and the child. This may be informative of the child's ability to perform language related tasks, but it tells us less about the same child's ability to use language in everyday communication. A child that scores low on a test might not experience problems using language in day-to-day activities, and vice versa. 


\section{Participants and recruitment}

At the outset of this thesis project, the aim was to recruit at least 25 children with DLD and 25 children with congenital bilateral sensorineural HI. While this goal was met for the children with DLD, only 14 children with HI were included. Further, variability in the sample of children with HI was extensive regarding hearing characteristics. The restricted sample size alone make reliable generalizations virtually impossible, and the heterogeneity in terms of hearing assistive technology (CI or HA) and time since implantation or fitting of HA further adds to this issue. Mixing children with CI, HA, or a combination of CI and HA together is questionable, and most previous research have investigated these groups separately. The decision to build the studies of the children with HI on group comparisons was in line with the original idea of the project, and with the ethical approval obtained. That said, other approaches, such as case studies, may have been more informative about WR and NWR, prosody and phonology in this group.

The children with DLD were diagnosed by their SLPs, and details about what informed the diagnostic decisions, or the type and amount of therapy each child had received, have not been available to the researchers. All children had a diagnosis of language disorder (Sw. språkstörning) according to ICD-10. However, it is not known what tests or observations were performed, or whether formal assessments of hearing or cognition were made.

Recruitment proved to be quite difficult, with large variations in turn-out between clinics. The researchers could only reach out to participants through clinicians and other staff, which is a common procedure in SLP research. However, this way of recruiting participants has a number of limitations. The workloads for clinicians are typically high, leaving little time for peripheral tasks such as informing and asking children and caregivers about research studies. Further, such tasks are often not part of clinicians' regular work assignments, and do not count toward productivity goals. Clinicians may also have insecurities about which participants to approach, and they might feel that patients are bothered by questions about study participation, or that they feel obliged to participate if asked. Clinicians may also fear that a child's participation in a scientific study would interfere with intervention. Another potential issue is failure of the researchers to convey the purpose and importance of a given study to clinicians, who in turn may feel less motivated to take part in recruitment. As a consequence, not all children who are eligible for inclusion are given information and opportunity to participate. These and other related factors influence the sampling. In extension, it affects the quality and usefulness of clinical research. 


\section{Limitations of the WR and NWR task}

The present thesis has relied heavily on the WR and NWR task. The reason for constructing a new task instead of using an existing one was the interest in the prosodic variation of Swedish words, and the will to exploit all of these features in the same material. Arguably, no human behavior is simple, and all efforts to measure it will inevitably be associated with confounding factors. Despite being procedurally straightforward, immediate repetition is a complex cognitive and linguistic activity, and all results must be interpreted with the limitations of the method used to measure it in mind. Some of the major methodological questions about the WR and NWR task are discussed below.

In the WR and NWR task, the children were told that they were going to hear real words prior to the WR part, and fake words before the NWR part. It is not clear that the concept of real words versus fake words made sense to the children. In normal word learning, a child (at least above a certain age) knows that a new word form has to represent something in the world, and that the words are used to communicate something. This is not the case for the encounter with known and unknown word forms in artificial immediate repetition tasks, where there is no context or communicative intent.

One of the methodological flaws of the WR and NWR task was that no procedure was undertaken to ensure that the real words were known to the children. It is possible that some of the words, especially the longer ones, were not in the vocabularies of the children. And, if that was the case, those words would functionally have been nonwords. A word learning phase prior to the WR and NWR task could have remedied this flaw to some extent, but it is not clear that this would have guaranteed that the children actually 'knew' the words at the time of testing. Another option would have been to check which children new the real words, and to exclude those children who didn't. Either of these alternatives would have required extended testing sessions, possibly divided between several visits.

The selection of nonword stimuli was based on judgments of wordlikeness by naïve listeners; the least wordlike nonwords were included in the task. However, neither the words nor the nonwords were controlled for phonotactic probability (the frequency with which a given phoneme sequence occurs in a language) or neighborhood density (the phonological similarity to other words). As both these factors influence repetition performance (Metsala \& Chisholm, 2010; Munson, Kurtz, \& Windsor, 2005), it is possible that, for example, the difference in repetition accuracy found between two length conditions may not have been due to length only, but also due to unequal phonotactic probabilities or neighborhood densities in the conditions. 
Calculators for these measures are easily accessible for English (e.g. Storkel \& Hoover, 2010), but not for Swedish.

The question of what is a word and what is a nonword has not been thoroughly addressed in the research literature. Can a word be a word more for some children, but less so to others? As touched upon above, a word is not a real word to a child just because it exists in a dictionary, or even if it likely is present in the ambient language. Full acquisition of a word, in terms of comprehension and usage in different contexts, is not the work of a moment, but takes place over time. Perhaps the division of sound strings into words and nonwords in a repetition task, such as the one used for the present thesis, is not necessarily all that meaningful. Instead, maybe all word size combinations of speech sounds and prosodic properties should be seen as more or less probable, based on linguistic and cultural context, phonological complexity, wordlikeness, neighborhood density and phonotactic probability, which in turn interacts with the intrinsic properties of the language user, such as phonological working memory, phonological processing skills, or characteristics and size of the vocabulary.

Words and nonwords were paired based on prosodic features, so that each nonword had the same stress pattern and tonal word accent as its word counterpart. Some slight variation in the exact realization of prosody between words and nonwords might be expected, however, since live voice recordings were used. Although prosody was perceptually judged to be the same in each word-nonword pair, no acoustic measures were employed as confirmation.

A consistent finding in studies I-III was that words were easier to repeat than nonwords, which was expected. The words and nonwords were not matched for syllable structure, which means that phonological complexity may have differed somewhat. Higher complexity is associated with lower repetition performance (Gallon, Harris, \& van der Lely, 2007). Thus, the results from comparisons between WR and NWR could have been influenced by this difference. Ideally, complexity should have been equal in both words and nonwords of the same length. However, complexity was comparable between the conditions, and the total number of complex syllables was actually higher in words. This indicates that the higher accuracy found for WR compared to NWR depended on other factors than phonological complexity. If anything, the higher complexity of the words could have caused smaller effects of stimulus type (word or nonword) than could be expected had complexity been equal.

The WR and NWR task was unbalanced concerning the number of items in each length condition. In order to include all possible combinations of stress and tonal word accent in words and nonwords up to five syllables long, there had to be, for example, a minimum of 3 two-syllable items, and 9 five-syllable items (see table 6 displaying the WR and NWR task). Ideally, the number of items should have been the 
same in all length conditions. However, this would have required a WR and NWR task with a total of at least 90 items (45 words and 45 nonwords), which would have been too tiresome for many children With the present design, different amounts of data were collected in each condition, and scores could not vary to the same degree in all conditions. For any given child, the result on e.g. stress in 2-syllable words could be $0 \%, 33.3 \%, 66.7 \%$ or $100 \%$, whereas in the 5 -syllable condition it could be $0 \%$, $11.1 \%, 22.2 \%, 33.3 \%$, and so on. Comparisons between items of different length in an individual child would be misleading, but sufficiently large sample sizes could still enable reliable group comparisons. On that note, none of the samples in the present theses was particularly large, especially not the group of children with HI.

All the children's productions in the WR and NWR task and the Phoneme Test were transcribed phonetically, including diacritics for primary stress and tonal word accent. The transcriptions were then used as the base for all segmental and prosodic production measures. Unfortunately, there is no indisputable criteria for what is correct and incorrect when calculating e.g. PCC. Taking the PCC measure as an example, several alternative approaches have been described (see e.g. Shriberg, Austin, Lewis, McSweeny, \& Wilson, 1997). In the present thesis, the criteria for correct production can be considered fairly strict. For example, substitutions were scored as incorrect regardless of whether it represented a systematic phonological simplifications process in the child or not. Further, many words and nonwords contained late acquired sounds that four- or five-year-olds cannot be expected to produce with adult-like accuracy, but this was not taken into account in the calculations of PCC, PVC or PPC. Consequently, the results presented in this thesis should not be regarded as adequately representative of the children's intelligibility. In defense of the method used, measures that take speech sound development or problems with expressive phonology into account, such as the PCC-Adjusted or PCC-Revised (Shriberg et al., 1997), would have required assumptions to be made about what errors could be expected from the children with DLD and HI. The problem becomes particularly evident in the children with HI, since the same phonological error may be directly hearing related, or related to problems at higher levels of processing, or both. In order to avoid different criteria for different groups, all errors were assessed in the same way for all children. 


\section{Directions for future research}

In the present thesis, children were studied who had DLD with mainly phonological and grammatical deficits. They represent only a subset of the heterogeneous population of children with DLD, and future studies should include children who exhibit other or more severe language problems. Conversely, it would also be interesting to study children with phonological and grammatical difficulties separately. The children with HI had very diverse background with regard to hearing, and included very few children, especially with CI. Studies of children with mild to moderate HI who wear HA, and children with CI (who typically have more severe HI), should be conducted with these groups separated, since the different hearing assistive technologies provide different hearing experiences. Further, the correlations found between unaided hearing level and repetition ability in the present thesis could motivate groups based on degree of HI. Finally, any studies of children with HI should include larger samples, regardless of grouping.

Both language and immediate repetition ability change during the course of development. Cross-sectional designs cannot capture changes over time, and do not enable inference about causality. Longitudinal studies could provide insights about e.g. the relationship between the ability to repeat nonwords and different language skills, and whether the nature of such a relationship appears to change. Given the importance of prosody in early development, children younger than those in the present thesis should be included.

Several findings warrant further examination of the relation between prosody and grammar in Swedish-speaking children with DLD and HI. First, the results of studies II and III suggested that the same underlying abilities may be involved in the repetition of stress and in grammatical ability. Second, the analyses of grammar in paper IV indicated that many of the most problematic grammatical morphemes in the Gramba test occurred in prosodically disadvantaged positions. Detailed analyses of morphology and syntax in relation to word and phrase level prosody could be both theoretically and clinically relevant. Studies of younger children with or without language disorders could inform about the interaction between prosody and grammar in the course of development, for example if prosodic ability at an early age could predict later grammatical ability. Further, investigations into potential prosodically conditioned grammatical problems could be of value in assessment and treatment of children with DLD or HI.

The investigations of phonology and prosody in the present thesis were confined to immediate repetition and picture naming targeting single words. It would be of great interest to examine phrase level phonology, as well as phonology in the context 
of conversation or narration. Future studies should also examine if the children who achieve low results on lexical prosody measures in repetition are also less successful when communicating in interaction with others. If so, it would be interesting to see if communicative problems appear to depend on the use of prosody.

NWR has been used extensively in the study of child language, and has been confirmed to be problematic for both children with DLD and children with HI. The main contribution of the present thesis to research concerned with NWR ability is the finding that tonal word accent appears to play a role in repetition. However, many of the details about how repetition performance varies as a function of the ability to use tonal features remain to be revealed. The WR and NWR task included too few items with the same combination of stress and tonal word accent to enable reliable, more discrete, comparisons between prosodic properties. Future studies should employ more focused experimental tasks that target specific prosodic features in a more controlled way. For example, differences between the tonal word accents could be investigated with a larger number of two-syllable nonwords with the same stress pattern, closely matched segmental makeup, and an equal number of items with tonal word accent 1 and 2 .

Analyses based on general measures (such as PCC) and group comparisons based on average performance only tell us if a difference could be found or not. While this can be a first step toward identifying important differences between children with typical and atypical language ability, such findings need to be complemented by other analyses. Variations and deviances in segmental production can be described in terms of subphonemic phonological features or articulatory gestures, and how these interact with each other, and with features at the prosodic level. Prosodic production can also be analyzed in more nuanced ways, for example with acoustic analyses. The finding that there were few significant differences between the children with DLD and the children with HI does not mean that there were no differences of importance that could have been revealed by more qualitative phonological analyses. Future studies should consider incorporation of both quantitative and qualitative measures, and should not rely solely on perceptual analyses. 


\section{CONCLUSIONS}

- Children with DLD and children with HI demonstrate lower performance compared to controls with TLD and normal hearing on both segmental and prosodic measures of prosodic and segmental phonological ability in immediate repetition tasks. Difficulties with prosody include both rhythmical and tonal properties, manifested as problems with the repetition of stress patterns and tonal word accents. Higher accuracy can be expected for tonal word accent production than for stress, vowels and consonants.

- The ability of children with DLD to repeat stress in real words is related to expressive grammar, but prosodic repetition does not reflect general language knowledge.

- In children with HI, repetition of both segments and prosody may be indicative of receptive vocabulary, phonological production during naming of familiar words, and expressive grammar. Repetition performance might be related to the degree of $\mathrm{HI}$ before cochlear implantation and/or fitting of hearing aids. However, the findings from the small and diverse group of children with $\mathrm{HI}$ in the present thesis did not support an effect of duration of CI or HA use on repetition or language ability.

- Children with DLD and children with HI demonstrate similar strengths and weaknesses in phonological and grammatical production, despite the fact that they develop language and cognition under different conditions-with and without normal hearing. Tonal word accent use and syntax are relatively unimpaired in DLD and HI children.

- Future research should include larger and more well defined samples, preferably using longitudinal study designs. Potential differences in phonological, including prosodic, ability and immediate repetition between children with DLD and HI should include both quantitative and qualitative methods, using data from both behavioral testing and communication in interaction. Further, perceptual as well as instrumental analyses should be employed. 


\section{SVENSK SAMMANFATTNING}

Fonologi är läran om språkets ljud och ljudsystem, det vill säga vilka ljud som finns i ett språk, regler för hur de kan kombineras, och hur de används för att förmedla betydelse. Till fonologin räknas prosodin - talets och språkets melodi och rytm. Prosodi används bland annat för att gruppera ljud och ord som hör samman, framhäva viktig information, reglera turtagning i samtal samt för att uttrycka känslotillstånd. På ordnivå kan prosodiska egenskaper användas för att göra skillnad i betydelse mellan ord som för övrigt har nästintill identiskt ljudinnehåll. Exempelvis ger betoningen olika betydelse i 'banan och ba'nan, medan det $i$ ett ordpar som anden (av and) och anden (av ande) är ordaccenten som gör skillnad.

Barn visar redan kort efter födelsen mer intresse för mänskligt tal och mänskliga röster än för andra ljud. Under det första levnadsåret ökar känsligheten för de ljudmönster som finns i det omgivande språket. Fram till ungefär sex månaders ålder kan ett spädbarn särskilja alla mänskliga språkljud, men redan vid ett års ålder har barnet svårt att uppfatta och diskriminera mellan ljud som inte ingår i modersmålet. Denna språkspecifika perception är till fördel för barnet, eftersom endast en begränsad uppsättning ljud behövs för att bygga ord och förmedla betydelse i ett givet språk. Det omgivande talet och språket avspeglas även i barnets joller som successivt anpassas efter de vuxnas melodi och rytm. Prosodins roll i språkutveckling är bland annat att möjliggöra för barnet att rikta uppmärksamheten mot information som är viktig och att uppfatta vilka ljud som hör samman i ord eller fraser. På det sättet underlättar prosodin tillägnandet av exempelvis grammatiska och lexikala enheter.

Barn med språkstörning och barn som har en hörselnedsättning uppvisar ofta fonologiska svårigheter, vilket kan få konsekvenser både för förmågan att förstå talat språk, och för förmågan att uttrycka sig. Medan det hos barn med språkstörning inte finns någon känd orsak till svårigheterna, antas de hos barn med hörselnedsättning bero på deras reducerade hörförmåga. Likartade språkliga nedsättningar förekommer alltså i dessa två grupper, trots att de har olika förutsättningar att utveckla talat språk. Dock finns med största sannolikhet en undergrupp av barn med hörselnedsättning som skulle ha språkliga problem även om de hade normal hörsel och som därmed kan vara i behov av särskild intervention.

Variationen mellan individer avseende språklig och kognitiv förmåga är stor hos såväl barn med typisk utveckling som hos barn med språkstörning eller hörselnedsättning. Det innebär en utmaning för barnhälsovården gällande att identifiera vilka av 
dessa barn som följer en typisk tal- och språkutveckling, och vilka som inte gör det. En uppgift som har visat sig användbar för att skilja mellan barn med typisk och atypisk språkförmåga är nonordsrepetition, där barnet lyssnar på påhittade ord och omedelbart repeterar dem så likt de kan. Uppgiften är komplex, och många faktorer kan påverka prestationen. Både fonologiskt arbetsminne och fonologisk bearbetningsförmåga antas vara inblandade, men det är inte klarlagt exakt vad nonordsrepetition mäter. Relativt få studier har undersökt vilken effekt nonordens prosodiska egenskaper har på repetitionsförmågan.

Syftet med föreliggande avhandling är att studera fonologi på ordnivå, med särskild tyngdpunkt på prosodi, hos barn med språkstörning och barn med hörselnedsättning. Ett ytterligare syfte är att beskriva fonologiska svårigheter i dessa grupper och att undersöka den möjliga diagnostiska och prediktiva användbarheten hos en ord- och nonordsrepetitionsuppgift som tar hänsyn till prosodiska egenskaper. De övergripande frågeställningarna var:

- Vad kännetecknar prosodisk och fonologisk produktion vid ord- och nonordsrepetition hos barn med språkstörning, barn med hörselnedsättning, och barn med typisk språkutveckling?

- Vilket förhållande har förmågan att repetera prosodiska egenskaper till övrig språkförmåga hos barn med språkstörning och barn med hörselnedsättning?

- Vilka likheter och skillnader uppvisar barn med språkstörning, barn med hörselnedsättning och barn med typisk språkutveckling avseende fonologisk produktion och expressiv grammatisk förmåga?

För att besvara dessa frågeställningar genomfördes fyra delstudier (I-IV), vilka beskrivs nedan. Totalt ingick 117 barn mellan fyra och sex år: två grupper barn med typisk språkutveckling (I och II-IV), en grupp barn med språkstörning (II och IV), och en grupp barn med hörselnedsättning (III och IV).

I delarbete I deltog 44 barn med typisk språkutveckling, uppdelade i en yngre (ålder 4;0-4;11 år;månader) och en äldre (ålder 5;0-5;11) grupp. Syftet var att undersöka förmågan att repetera ord och nonord med särskilt fokus på hur prosodiska egenskaper påverkar produktion av segment (konsonanter och vokaler). Generellt presterade de äldre barnen bättre än de yngre på repetition av både prosodiska egenskaper och segment. Prosodiska egenskaper var enklare att repetera än segment och särskilt höga poäng erhölls på repetition av ordaccenter, medan konsonanter repeterades minst precist. Resultaten visade även att segment repeterades bättre i ord än $\mathrm{i}$ nonord, medan motsvarande skillnad inte fanns för prosodiska egenskaper. Avseende effekten av prosodiska egenskaper på segmentrepetition erhöll barnen lägre resultat på repetition av segment i ord och nonord med många stavelser. Segment repeterades 
också bättre i ord och nonord med accent 2 jämfört med accent 1 av de äldre barnen, medan denna effekt av accenttyp bara fanns för ord hos de yngre barnen. Sammanfattningsvis tyder resultaten från delarbete I på att förmågan att repetera ord och nonord utvecklas mellan fyra och sex års ålder, och att prosodiska egenskaper har betydelse för hur framgångsrikt barn med typisk språkutveckling repeterar vokaler och konsonanter.

Målet med delarbete II var att studera repetition av betoning och ordaccenter i ord och nonord hos barn med språkstörning samt att undersöka potentiella korrelationer mellan repetition av prosodiska egenskaper och mått på språklig förmåga. Deltagarna var 30 barn mellan fyra och sex år, med huvudsakligen fonologiska och grammatiska svårigheter, och 29 barn med typisk språkutveckling. Resultaten visade att barnen med språkstörning presterade signifikant lägre än barnen med typisk språkutveckling på repetition av betoningsmönster och ordaccenter. Det vanligast förekommande felet på repetition av betoning var utelämningar av obetonade stavelser, särskilt i pretonisk position, det vill säga före den betonade stavelsen. Repetition av prosodiska egenskaper korrelerade inte med fonologisk produktion av bekanta ord vid bildbenämning eller med receptivt ordförråd. Däremot fanns en signifikant korrelation mellan repetition av betoning $\mathrm{i}$ ord och expressiv grammatisk förmåga. En möjlig förklaring till det potentiella sambandet mellan repetition av betoning och expressiv grammatik är att många grammatiska morfem i svenskan utgör obetonade stavelser, ofta i pretonisk position. Svårigheter att hantera den prosodiska strukturen kan få negativa konsekvenser för tillägnandet och användningen av sådana morfem, och det är möjligt att det avspeglas i barnens förmåga att repetera betoningsmönster i ord.

Delarbete III inkluderade en grupp om 14 barn med mild till grav hörselnedsättning som använde konventionell hörapparat, cochleaimplantat eller en kombination av båda. Även 29 barn med normal hörsel och typisk språkutveckling deltog. Det första syftet var att undersöka prosodiska och segmentella aspekter av nonordsrepetition hos barnen med hörselnedsättning och att jämföra deras resultat med kontrollgruppens. Det andra syftet var att utforska potentiella associationer mellan nonordsrepetition och språk, icke-verbal kognitiv förmåga, moderns utbildningsnivå samt hörselbakgrundsvariabler. Resultaten indikerade att förmågan att repetera ordaccent, betoning, konsonanter och vokaler var lägre hos barnen med hörselnedsättning jämfört med barnen med typisk utveckling. Prestationen på repetition av ordaccenter var dock relativt hög i förhållande till betoning, vokaler och konsonanter. I tvåstaviga nonord fanns ingen skillnad mellan grupperna avseende ordaccenter. Vidare repeterades vokaler med större framgång än betoning av barnen med hörselnedsättning, vilket tyder på att prosodiska egenskaper inte nödvändigtvis är enklare att repetera än segment. Konsonanter utmärkte sig dock som särskilt svåra att repetera. I likhet med 
resultaten i delarbete II, var utelämning av obetonade stavelser i pretonisk position det vanligaste felet på repetition av betoningsmönster hos barnen med hörselnedsättning. Korrelationsanalyser visade att de barn som presterade lågt på repetition på något av repetitionsmåtten (ordaccent, betoning och segment) också uppnådde lägre resultat på fonologisk produktion vid benämning, expressiv grammatik och receptivt ordförråd. Dessutom korrelerade utfallet på nonordsrepetition med den grad av hörselnedsättning barnen hade innan de fick sina hörapparater eller implantat. Däremot hittades inga korrelationer till hur gamla barnen var när de fick sina hörhjälpmedel eller hur länge de hade använt dem.

I delarbete IV jämfördes 30 barn med språkstörning, 14 barn med hörselnedsättning och 29 barn med normal hörsel och typisk språkutveckling. Jämförelsemåtten var fonologisk produktion vid benämning och ord- och nonordsrepetition samt grammatisk produktion av morfologi och syntax. Resultaten på produktion av konsonanter, vokaler, betoningsmönster och ordaccenter följde nästan genomgående samma mönster vid benämning som vid ord- och nonordsrepetition: barnen med språkstörning och barnen med hörselnedsättning presterade lägre än barnen med typisk språkutveckling men skiljde sig inte signifikant från varandra. Ett undantag var repetition av ordaccenter i ord, där barnen med hörselnedsättning uppnådde signifikant lägre poäng än barnen med språkstörning och barnen med typisk utveckling som i sin tur inte skilde sig åt. Analyser av samtliga deluppgifter i grammatiktestet Gramba visade att barnen med språkstörning och barnen med hörselnedsättning hade svårigheter med de flesta morfologiuppgifterna jämfört med barnen med typisk språkutveckling. Undantagen var presens- och pluralböjning där ingen skillnad mellan grupperna fanns. Medan de morfologiska aspekterna var problematiska framträdde användning av syntaktiska konstruktioner som en styrka hos barnen med språkstörning och hörselnedsättning. Få signifikanta skillnader i grammatisk förmåga mellan barnen med språkstörning och barnen med hörselnedsättning hittades. Det enda undantaget var kongruens i predikativ, där ett subjekt, kopulan "är" och ett kongruensböjt adjektiv måste användas tillsammans.

De sammantagna fynden från delarbetena ledde fram till följande slutsatser:

- Barn med språkstörning och barn med hörselnedsättning har lägre förmåga än barn med normal hörsel och typisk språkutveckling att repetera prosodi och segment i ord och nonord. Svårigheter med prosodiska egenskaper inkluderar både rytmiska och tonala drag, det vill säga betoning och ordaccenter. Högre precision kan dock förväntas för ordaccenter än för betoning.

- Förmågan hos barn med språkstörning att repetera betoning i ord är relaterad till expressiv grammatik, men repetition av prosodiska egenskaper avspeglar inte generell språklig förmåga. 
- Hos barn med hörselnedsättning kan problem med repetition av segment och prosodi i nonord indikera svårigheter med receptivt ordförråd, expressiv grammatik och segmentproduktion vid benämning. Repetitionsförmågan kan även vara relaterad till graden av hörselnedsättning innan implantation eller hörapparatanpassning. Med tanke på det ringa antalet deltagare gruppens heterogenitet är generaliserbarheten låg och resultaten bör tolkas med stor försiktighet.

- Barn med språkstörning och barn med hörselnedsättning uppvisar liknande styrkor och svagheter avseende fonologisk och grammatisk produktion, trots att de utvecklar talat språk under olika förhållanden - med och utan normal hörsel. Användning av ordaccenter och syntax är relativt opåverkad. Framtida studier bör dock inkludera kvalitativa analysmetoder för att belysa likheter och skillnader mellan dessa grupper. Även data från spontantal i interaktion bör undersökas. 


\section{REFERENCES}

Adams, A. M., \& Gathercole, S. E. (1995). Phonological working memory and speech production in preschool children. Journal of Speech, Language, and Hearing Research, 38(2), 403-414.

Adams, A. M., \& Gathercole, S. E. (1996). Phonological Working Memory and Spoken Language Development in Young Children. Quarterly Journal of Experimental Psychology Section A: Human Experimental Psychology, 49(1), 216-233. doi: $10.1080 / 713755610$

Adams, A. M., \& Gathercole, S. E. (2000). Limitations in working memory: Implications for language development. International Journal of Language and Communication Disorders, 35(1), 95-116.

Alford, R. L., Arnos, K. S., Fox, M., Lin, J. W., Palmer, C. G., Pandya, A., . . YoshinagaItano, C. (2014). American college of medical genetics and genomics guideline for the clinical evaluation and etiologic diagnosis of hearing loss. Genetics in Medicine, 16(4), 347-355. doi:10.1038/gim.2014.2

Andersson, J., \& Martikainen, P. (2013). Utprö̈ning och prosodisk analys av ord- och nonordsreptition på en grupp barn med typisk utveckling. (Master thesis), Linköpings universitet, Linköping.

Arbisi-Kelm, T., \& Beckman, M. E. (2009). Prosodic structure and consonant development across languages. In M. Vigario, S. Frota, \& M. J. Freitas (Eds.), Phonetics and Phonology: Interactions and interrelations (pp. 109-136). Amsterdam: John Benjamins Publishing Company.

Arlinger, S. (2007). Nordisk lärobok i audiologi. Bromma: CA Tegnér.

ASHA. (2018). Degree of hearing loss. Retrieved from https://www.asha.org/public/hearing/degree-of-hearing-loss/

Baddeley, A. D. (1992). Working Memory. Science, 255(5044), 556-559.

Baddeley, A. D. (2000). The episodic buffer: A new component of working memory? Trends in cognitive sciences, 4(11), 417-423. doi:10.1016/S1364-6613(00)01538-2

Baddeley, A. D. (2003). Working memory and language: An overview. Journal of Communication Disorders, 36(3), 189-208. doi:10.1016/S0021-9924(03)00019-4

Baddeley, A. D. (2012). Working memory: Theories, models, and controversies (Vol. 63, pp. 1-29).

Baddeley, A. D., Gathercole, S. E., \& Papagno, C. (1998). The Phonological Loop as a Language Learning Device. Psychological Review, 105(1), 158-173.

Baddeley, A. D., \& Hitch, G. J. (1974). Working memory. In G. A. Bower (Ed.), The Psychology of learning and motivation: Advances in research and theory (pp. 47-89). New York: Academic Press.

Baddeley, A. D., Hitch, G. J., \& Allen, R. J. (2009). Working memory and binding in sentence recall. Journal of Memory and Language, 61(3), 438-456. doi:10.1016/j.jml.2009.05.004

Ball, M. J. (2016). Principles of clinical phonology: theoretical approaches. New York, NY: Routledge.

Ball, M. J., Rutter, B., \& Müller, N. (2010). Phonology for communication disorders. New York: Psychology Press.

Barry, J. G., Yasin, I., \& Bishop, D. V. M. (2007). Heritable risk factors associated with language impairments. Genes, Brain and Behavior, 6(1), 66-76. doi:10.1111/j.1601183X.2006.00232.x

Beckman, M. E., \& Pierrehumbert, J. B. (1986). Intonational structure in Japanese and English. Phonology Yearbook, 3, 15-70. 
Benjamini, Y., \& Hochberg, Y. (1995). Controlling the false discovery rate: A practical and powerful approach to multiple testing. Journal of the Royal Statistical Society Series BMethodological, 57(1), 289-300.

Bishop, D. V. M. (1997). Uncommon understanding: Comprehension in specific language impairment. Hove: Psychology Press.

Bishop, D. V. M. (2006). What causes specific language impairment in children? Current Directions in Psychological Science, 15(5), 217-221. doi:10.1111/j.14678721.2006.00439.x

Bishop, D. V. M. (2013). Cerebral Asymmetry and Language Development: Cause, Correlate, or Consequence? Science, 340(6138).

Bishop, D. V. M. (2014). Ten questions about terminology for children with unexplained language problems. International Journal of Language and Communication Disorders, 49(4), 381-415. doi:10.1111/1460-6984.12101

Bishop, D. V. M., North, T., \& Donlan, C. (1996). Nonword repetition as a behavioural marker for inherited language impairment: Evidence from a twin study. Journal of Child Psychology and Psychiatry and Allied Disciplines, 37(4), 391-403. doi:10.1111/j.1469-7610.1996.tb01420.x

Bishop, D. V. M., Snowling, M. J., Thompson, P. A., Greenhalgh, T., Adams, C., Archibald, L., . . . Whitehouse, A. (2016). CATALISE: A multinational and multidisciplinary Delphi consensus study. Identifying language impairments in children. PLoS ONE, 11(7). doi:10.1371/journal.pone.0158753

Bishop, D. V. M., Snowling, M. J., Thompson, P. A., Greenhalgh, T., \& CATALISE-2. (2017). Phase 2 of CATALISE: a multinational and multidisciplinary Delphi consensus study of problems with language development: Terminology. Journal of Child Psychology and Psychiatry, 58(10), 1068-1080. doi:10.1111/jcpp.12721

Borg, E., Edquist, G., Reinholdson, A. C., Risberg, A., \& McAllister, B. (2007). Speech and language development in a population of Swedish hearing-impaired pre-school children, a cross-sectional study. International journal of pediatric otorbinolaryngology, 71(7), 1061-1077. doi:10.1016/j.ijporl.2007.03.016

Bortolini, U., \& Leonard, L. B. (2000). Phonology and children with specific language impairment: Status of structural constraints in two languages. Journal of Communication Disorders, 33(2), 131-150. doi:10.1016/S0021-9924(99)00028-3

Bowey, J. A. (1996). On the association between phonological memory and receptive vocabulary in five-year-olds. Journal of experimental child psychology, 63(1), 44-78. doi:10.1006/jecp.1996.0042

Bowey, J. A. (2001). Nonword repetition and young children's receptive vocabulary: A longitudinal study. Applied Psycholinguistics, 22(3), 441-469. doi:10.1017/s0142716401003083

Bowey, J. A. (2006). Clarifying the phonological processing account of nonword repetition. Applied Psycholinguistics, 27(4), 548-552. doi:10.1017.S0142716406060401

Brehmer, D. (2014). Taltest [Computer software] (Version 1.0).

Briscoe, J., Bishop, D. V. M., \& Norbury, C. F. (2001). Phonological processing, language, and literacy: A comparison of children with mild-to-moderate sensorineural hearing loss and those with specific language impairment. Journal of Child Psychology and Psychiatry and Allied Disciplines, 42(3), 329-340. doi:10.1017/S0021963001007041

Brown, H. D. (2007). Principles of language learning and teaching (5th ed.). New York, NY: Pearson Education.

Bruce, G. (1977). Swedish word accents in sentence perspective. Lund: Liber.

Bruce, G. (2010). Vår fonetiska geografi. Om svenskans accenter, melodi och uttal. Lund: Studentlitteratur.

Bruce, G. (2012). Allmän och svensk prosodi. Lund, Sweden: Studentlitteratur. 
Carter, A. K., Dillon, C. M., \& Pisoni, D. B. (2002). Imitation of nonwords by hearing impaired children with cochlear implants: Suprasegmental analyses. Clinical Linguistics and Phonetics, 16(8), 619-638. doi:10.1080/02699200021000034958

Casserly, E. D., \& Pisoni, D. B. (2013). Nonword repetition as a predictor of long-term speech and language skills in children with cochlear implants. Otology and Neurotology, 34(3), 460-470. doi:10.1097/MAO.0b013e3182868340

Chiat, S. (2001). Mapping theories of developmental language impairment: Premises, predictions and evidence. Language and Cognitive Processes, 16(2-3), 113-142. doi:10.1080/01690960042000012

Chiat, S., \& Roy, P. (2007). The preschool repetition test: An evaluation of performance in typically developing and clinically referred children. Journal of Speech, Language, and Hearing Research, 50(2), 429-443.

Ching, T. Y. C., Dillon, H., Day, J., Crowe, K., Close, L., Chisholm, K., \& Hopkins, T. (2009). Early language outcomes of children with cochlear implants: Interim findings of the NAL study on longitudinal outcomes of children with hearing impairment. Cochlear Implants International, 10(SUPPL. 1), 28-32. doi:10.1002/cii.382

Christophe, A., Mehler, J., \& Sebastián-Gallés, N. (2001). Perception of Prosodic Boundary Correlates by Newborn Infants. Infancy, 2(3), 385-394.

Clark, J. G. (1981). Uses and abuses of hearing loss classification. ASHA, 23(7), 493-500.

Coady, J. A., \& Evans, J. L. (2008). Uses and interpretations of non-word repetition tasks in children with and without specific language impairments (SLI). International Journal of Language and Communication Disorders, 43(1), 1-40. doi:10.1080/13682820601116485

Conti-Ramsden, G., \& Adams, C. (1995). Transitions from the clinic to school: The changing picture of specific language impaired children from pre-school to school age. Journal of Clinical Speech and Language Studies, 5, 1-11.

Conti-Ramsden, G., Botting, N., \& Faragher, B. (2001). Psycholinguistic markers for specific language impairment (SLI). Journal of Child Psychology and Psychiatry and Allied Disciplines, 42(6), 741-748.

Conti-Ramsden, G., Crutchley, A., \& Botting, N. (1997). The extent to which psychometric tests differentiate subgroups of children with SLI. Journal of Speech, Language, and Hearing Research, 40(4), 765-777.

Conti-Ramsden, G., Durkin, K., Toseeb, U., Botting, N., \& Pickles, A. (2018). Education and employment outcomes of young adults with a history of developmental language disorder. International Journal of Language and Communication Disorders, 53(2), 237-255. doi:10.1111/1460-6984.12338

Cowan, N. (1999). An embedded-processes model of working memory. In A. Miyake \& P. Shah (Eds.), Models of working memory: Mechanisms of active maintenance and executive control (Vol. 20, pp. 506). Cambridge: Cambridge University Press.

Cowan, N., \& Kail, R. (1996). Covert processes and their development in short-term memory. In S. Gathercole (Ed.), Models of short-term memory (pp. 29-50). Hove: Erlbaum Associates, Ltd.

Cruttenden, A. (1997). Intonation. Cambridge: Cambridge University Press.

de Boysson-Bardies, B., \& Vihman, M. M. (1991). Adaptation to language: Evidence from babbling and first words in four languages. Language, 297-319.

Delage, H., \& Tuller, L. (2007). Language development and mild-to-moderate hearing loss: Does language normalize with age? Journal of Speech, Language, and Hearing Research, 50(5), 1300-1313. doi:10.1044/1092-4388(2007/091)

Demuth, K. (2014). Prosodic licensing and the development of phonological and morphological representations. In A. Farris-Trimble \& J. Barlow (Eds.), Perspectives 
on phonological theory and development: In honor of Daniel A. Dinnsen (pp. 11-24): John Benjamins Publishing Company.

DePaolis, R. A., Vihman, M. M., \& Kunnari, S. (2008). Prosody in production at the onset of word use: A cross-linguistic study. Journal of Phonetics, 36(2), 406-422. doi:10.1016/j.wocn.2008.01.003

Dillon, C. M., Cleary, M., Pisoni, D. B., \& Carter, A. K. (2004). Imitation of nonwords by hearing-impaired children with cochlear implants: Segmental analyses. Clinical Linguistics and Phonetics, 18(1), 39-55. doi:10.1080/0269920031000151669

Dispaldro, M., Benelli, B., Marcolini, S., \& Stella, G. (2009). Real-word repetition as a predictor of grammatical competence in Italian children with typical language development. International Journal of Language \& Communication Disorders, 44(6), 941961. doi:10.3109/13682820802491794

Dispaldro, M., Deevy, P., Altoé, G., Benelli, B., \& Leonard, L. B. (2011). A cross-linguistic study of real-word and non-word repetition as predictors of grammatical competence in children with typical language development. International Journal of Language and Communication Disorders, 46(5), 564-578. doi:10.1111/j.14606984.2011.00008.x

Dispaldro, M., Leonard, L. B., \& Deevy, P. (2013a). Clinical markers in Italian-speaking children with and without specific language impairment: A study of non-word and real word repetition as predictors of grammatical ability. International Journal of Language and Communication Disorders, 48(5), 554-564. doi:10.1111/1460-6984.12032

Dispaldro, M., Leonard, L. B., \& Deevy, P. (2013b). Real-word and nonword repetition in Italian-speaking children with specific language impairment: A study of diagnostic accuracy. Journal of Speech, Language, and Hearing Research, 56(1), 323-336. doi:10.1044/1092-4388(2012/11-0304)

Dollaghan, C. A. (2011). Taxometric analyses of specific language impairment in 6-year-old children. Journal of Speech, Language, and Hearing Research, 54(5), 1361-1371. doi:10.1044/1092-4388(2011/10-0187)

Dunn, L. M., \& Dunn, L. M. (1997). PPVT-III: Peabody Picture Vocabulary Test.: American Guidance Service.

Dyck, M. J., Piek, J. P., \& Patrick, J. (2011). The validity of psychiatric diagnoses: The case of 'specific' developmental disorders. Research in developmental disabilities, 32(6), 27042713. doi:10.1016/j.ridd.2011.06.001

Echols, C. H., Crowhurst, M. J., \& Childers, J. B. (1997). The perception of rhythmic units in speech by infants and adults. Journal of Memory and Language, 36(2), 202-225. doi:10.1006/jmla.1996.2483

Eisenberg, L. S. (2007). Current state of knowledge: Speech recognition and production in children with hearing impairment. Ear and Hearing, 28(6), 766-772. doi:10.1097/AUD.0b013e318157f01f

Elert, C.-C. (1964). Phonologic studies of quantity in Swedish : based on material from Stockholm speakers. Uppsala: Almqwist \& Wiksell.

Elert, C.-C. (2000). Allmän och svensk fonetik. Stockholm: Norstedt.

Engstrand, O., Williams, K., \& Lacerda, F. (2003). Does babbling sound native? Listener responses to vocalizations produced by Swedish and American 12- and 18-montholds. Phonetica, 60(1), 17-44. doi:10.1159/000070452

Ericsson, K. A., \& Kintsch, W. (1995). Long-term working memory. Psychological Review, 102(2), 211-245.

Ertmer, D. J., \& Goffman, L. (2011). Speech production accuracy and variability in young cochlear implant recipients: Comparisons with typically developing age-peers. Journal of Speech, Language, and Hearing Research, 54(1), 177-189. doi:10.1044/10924388(2010/09-0165) 
Faes, J., Gillis, J., \& Gillis, S. (2016). Phonemic accuracy development in children with cochlear implants up to five years of age by using Levenshtein distance. Journal of Communication Disorders, 59, 40-58. doi:10.1016/j.jcomdis.2015.09.004

Finitzo, T., Albright, K., \& O'Neal, J. (1998). The newborn with hearing loss: Detection in the nursery. Pediatrics, 102(6), 1452-1460.

Fortnum, H. M., Marshall, D. H., \& Summerfield, A. Q. (2002). Epidemiology of the UK population of hearing-impaired children, including characteristics of those with and without cochlear implants - audiology, aetiology, comorbidity and affluence. International Journal of Audiology, 41(3), 170-179. doi:10.3109/14992020209077181

Frazier, L., Carlson, K., \& Clifton Jr, C. (2006). Prosodic phrasing is central to language comprehension. Trends in cognitive sciences, 10(6), 244-249. doi:10.1016/j.tics.2006.04.002

Fyrberg, Å., Gustavsson, I., \& Lundälv, E. (2001). PPVT-III 1997. Form III A. Översättning och bearbetning. Version 011118.

Gallon, N., Harris, J., \& van der Lely, H. K. J. (2007). Non-word repetition: An investigation of phonological complexity in children with Grammatical SLI. Clinical Linguistics \& Phonetics, 21(6), 435-455. doi:10.1080/02699200701299982

Gathercole, S. E. (2006). Nonword Repetition and Word Learning: The Nature of the Relationship. Applied Psycholinguistics, 27(4), 513-543.

Gathercole, S. E., \& Baddeley, A. D. (1990). Phonological memory deficits in language disordered children: Is there a causal connection? Journal of Memory and Language, 29(3), 336-360. doi:10.1016/0749-596x(90)90004-j

Gathercole, S. E., Willis, C. S., Emslie, H., \& Baddeley, A. D. (1992). Phonological Memory and Vocabulary Development During the Early School Years: A Longitudinal Study. Developmental psychology, 28(5), 887-898.

Geers, A. E. (2003). Predictors of reading skill development in children with early cochlear implantation. Ear and Hearing, 24(1 SUPPL.), 59S-68S.

Geers, A. E., \& Sedey, A. L. (2011). Language and verbal reasoning skills in adolescents with 10 or more years of cochlear implant experience. Ear and hearing, 32(1 Suppl), 39S-48S.

Gerken, L. (1991). The metrical basis for children's subjectless sentences. Journal of Memory and Language, 30(4), 431-451. doi:10.1016/0749-596x(91)90015-c

Gerken, L. (1994). A metrical template account of children's weak syllable omissions from multisyllabic words. Journal of Child Language, 21(3), 565-584.

Gerken, L. (1996). Prosodic structure in young children's language production. Language, 72(4), 683-712. doi:10.2307/416099

Girbau, D. (2016). The Non-word Repetition Task as a clinical marker of Specific Language Impairment in Spanish-speaking children. First Language, 36(1), 30-49. doi:10.1177/0142723715626069

Gordon, R. L., Fehd, H. M., \& McCandliss, B. D. (2015). Does music training enhance literacy skills? A meta-analysis. Frontiers In Psychology, 6(DEC). doi:10.3389/fpsyg.2015.01777

Gordon, R. L., Jacobs, M. S., Schuele, C. M., \& McAuley, J. D. (2015). Perspectives on the rhythm-grammar link and its implications for typical and atypical language development. In E. Bigand, B. Tillmann, I. Peretz, R. J. Zatorre, L. Lopez, \& M. Majno (Eds.), Neurosciences and Music V: Cognitive Stimulation and Rehabilitation (Vol. 1337, pp. 16-25).

Gordon, R. L., Shivers, C. M., Wieland, E. A., Kotz, S. A., Yoder, P. J., \& McAuley, J. D. (2015). Musical rhythm discrimination explains individual differences in grammar skills in children. Developmental Science, 18(4), 635-644. doi:10.1111/desc.12230 
Graf Estes, K., Evans, J. L., \& Else-Quest, N. M. (2007). Differences in the nonword repetition performance of children with and without specific language impairment: A meta-analysis. Journal of Speech, Language, and Hearing Research, 50(1), 177-195. doi:10.1044/1092-4388(2007/015)

Graham, S. A., \& Fisher, S. E. (2013). Decoding the genetics of speech and language. Current Opinion in Neurobiology, 23(1), 43-51. doi:10.1016/j.conb.2012.11.006

Halliday, L. F., Tuomainen, O., \& Rosen, S. (2017). Language development and impairment in children with mild to moderate sensorineural hearing loss. Journal of Speech, Language, and Hearing Research, 60(6), 1551-1567. doi:10.1044/2016_JSLHRL-16-0297

Hansson, K., \& Nettelbladt, U. (2004). Gramba. Grammatiktest för barn [Grammatical assessment for children]. Malmö, Sweden: Pedagogisk Design.

Hegarty, L., \& Faulkner, A. (2013). The perception of stress and intonation in children with a cochlear implant and a hearing aid. Cocblear Implants International, 14(SUPPL. 4), S35-S39. doi:10.1179/1467010013Z.000000000132

Hellqvist, B. (1989). Nya SIT - Språkligt impressivt test för barn LLanguage comprehension test for children]. Löddeköpinge: Pedagogisk Design.

Hellqvist, B. (1995). Fonemtest [Phoneme test]. Löddeköpinge: Pedagogisk design.

Hockett, C. F. (1960). A course in modern linguistics. London: Macmillan.

Hockey, H. (2014). Which skills influence pre-school children's repetition of words, non-words and sentences?. City University London, Unpublished Doctoral Thesis.

Holmberg, E., \& Stenkvist, H. (1983). Nya Lundamaterialet: Kartläggning och bedömning av barns språkliga förmaiga [The Lund test of phonology and grammar]. Malmö: Utbildningsproduktion.

Holt, C. M., Demuth, K., \& Yuen, I. (2016). The Use of Prosodic Cues in Sentence Processing by Prelingually Deaf Users of Cochlear Implants. Ear and Hearing, 37(4), E256-E262. doi:10.1097/aud.0000000000000253

Horne, M. (2013). Acquisition of prosody. Word accents, phrasing, and morphosyntax in a Swedish-English bilingual child at 30-32 months of age. In A. Flyman Mattsson \& C. Norrby (Eds.), Language Acquisition and Use in Multilingual Contexts (pp. 60-69).

Ibertsson, T., Willstedt-Svensson, U., Radeborg, K., \& Sahlén, B. (2008). A methodological contribution to the assessment of nonword repetition - A comparison between children with specific language impairment and hearing-impaired children with hearing aids or cochlear implants. Logopedics Phoniatrics Vocology, 33(4), 168-178. doi:10.1080/14015430801945299

Ito, J., \& Mester, A. (2006). Prosodic adjunction in Japanese compounds. Paper presented at the Formal approaches to Japanese linguistics.

Jusczyk, P. W. (1997). The Discovery of Spoken Language. Cambridge: MIT Press.

Kadin, G., \& Engstrand, O. (2005). Tonal word accents produced by Swedish 18- and 24-montholds. Paper presented at the Proc. Fonetik 2005.

Kalnak, N., Peyrard-Janvid, M., Forssberg, H., \& Sahlén, B. (2014). Nonword repetition A clinical marker for specific language impairment in Swedish associated with parents' language-related problems. PLOS ONE, 9(2). doi:10.1371/journal.pone.0089544

Kochhar, A., Hildebrand, M. S., \& Smith, R. J. H. (2007). Clinical aspects of hereditary hearing loss. Genetics in Medicine, 9(7), 393-408. doi:10.1097/GIM.0b013e3180980bd0

Kral, A., Kronenberger, W. G., Pisoni, D. B., \& O'Donoghue, G. M. (2016). Neurocognitive factors in sensory restoration of early deafness: a connectome model. The Lancet Neurology, 15(6), 610-621. doi:https://doi.org/10.1016/S14744422(16)00034-X 
Kral, A., \& Sharma, A. (2012). Developmental neuroplasticity after cochlear implantation. Trends in neurosciences, 35(2), 111-122. doi:10.1016/j.tins.2011.09.004

Krishnan, S., Watkins, K. E., \& Bishop, D. V. M. (2016). Neurobiological Basis of Language Learning Difficulties. Trends in cognitive sciences, 20(9), 701-714.

Kronenberger, W. G., Beer, J., Castellanos, I., Pisoni, D. B., \& Miyamoto, R. T. (2014). Neurocognitive risk in children with cochlear implants. JAMA Otolaryngology - Head and Neck Surgery, 140(7), 608-615. doi:10.1001/jamaoto.2014.757

Kuhl, P. K. (2004). Early language acquisition: cracking the speech code. Nature Reviens Neuroscience, 5(11), 831-843. doi:10.1038/nrn1533

Kuronen, M. (2000). Vokaluttalets akustik i sverigesvenska, finlandssvenska och finska. Jyväskylä: University of Jyväskylä.

Lahiri, A., Wetterlin, A., \& Jönsson-Steiner, E. (2005). Lexical specification of tone in North Germanic. Nordic Journal of Linguistics, 28(1), 61-96. doi:10.1017/S0332586505001320

Lauro, L. J. R., Reis, J., Cohen, L. G., Cecchetto, C., \& Papagno, C. (2010). A case for the involvement of phonological loop in sentence comprehension. Neuropsychologia, 48(14), 4003-4011. doi:10.1016/j.neuropsychologia.2010.10.019

Law, J., Reilly, S., \& Snow, P. C. (2013). Child speech, language and communication need re-examined in a public health context: A new direction for the speech and language therapy profession. International Journal of Language and Communication Disorders, 48(5), 486-496. doi:10.1111/1460-6984.12027

Leonard, L. B., McGregor, K. K., \& Allen, G. D. (1992). Grammatical morphology and speech perception in children with specific language impairment. Journal of Speech and Hearing Research, 35(5), 1076-1085.

Limb, C. J., \& Roy, A. T. (2014). Technological, biological, and acoustical constraints to music perception in cochlear implant users. Hearing research, 308(Supplement C), 1326. doi:https://doi.org/10.1016/j.heares.2013.04.009

Linell, P. (1978). Vowel length and consonant length in Swedish word level phonology. In E. Gårding, G. Bruce, \& R. Bannert (Eds.), Nordic prosody I: Department of Linguistics, Lund University.

Liu, H., Liu, S., Kirk, K. I., Zhang, J., Ge, W., Zheng, J., . . Ni, X. (2015). Longitudinal performance of spoken word perception in Mandarin pediatric cochlear implant users. International journal of pediatric otorbinolaryngology, 79(10), 1677-1682. doi:10.1016/j.ijporl.2015.07.023

Marshall, C. R., Harcourt-Brown, S., Ramus, F., \& van der Lely, H. K. J. (2009). The link between prosody and language skills in children with specific language impairment (SLI) and/or dyslexia. International Journal of Language \& Communication Disorders, 44(4), 466-488.

Martinet, A. (1949). La double articulation linguistique. Travaux du Cercle linguistique de Copenhague, 5, 30-37.

Mayes, A. K., Reilly, S., \& Morgan, A. (2015). Neural correlates of childhood language disorder: a systematic review. Developmental Medicine \& Child Neurology, 57(8), 706717. doi:doi: $10.1111 /$ dmcn.12714

McCarthy, J., \& Prince, A. (1990). Prosodic morphology and templatic morphology. Paper presented at the Perspectives on Arabic linguistics II: Papers from the second annual symposium on Arabic linguistics.

Mehra, S., Eavey, R. D., \& Keamy, D. G. (2009). The epidemiology of hearing impairment in the United States: Newborns, children, and adolescents. Otolaryngology - Head and Neck Surgery, 140(4), 461-472. doi:https://doi.org/10.1016/j.otohns.2008.12.022

Melby-Lervåg, M., Lervåg, A., Lyster, S. A. H., Klem, M., Hagtvet, B., \& Hulme, C. (2012). Nonword-Repetition Ability Does Not Appear to Be a Causal Influence on 
Children's Vocabulary Development. Psychological Science, 23(10), 1092-1098. doi:10.1177/0956797612443833

Meltzoff, A. N., Kuhl, P. K., Movellan, J., \& Sejnowski, T. J. (2009). Foundations for a new science of learning. Science, 325(5938), 284-288. doi:10.1126/science.1175626

Meschi, E., Vignoles, A., \& Lindsay, G. (2010). An investigation of pupils with speech, language and communication needs (SLCN). G. Lindsay, J. Dockrell, J. Law and S. Roulstone (eds). Department For Education, The Better Communication Research Programme First Interim Report. December. Nottingham: Department for Education.

Metsala, J. L. (1999). Young children's phonological awareness and nonword repetition as a function of vocabulary development. Journal of educational psychology, 91(1), 3-19.

Metsala, J. L., \& Chisholm, G. M. (2010). The influence of lexical status and neighborhood density on children's nonword repetition. Applied Psycholinguistics, 31(3), 489-506.

Metsala, J. L., \& Walley, A. C. (1998). Spoken vocabulary growth and the segmental restructuring of lexical representations: Precursors to phonemic awareness and early reading ability. In J. L. Metsala \& L. C. Ehri (Eds.), Word recognition in beginning literacy (pp. 89-120). Mawah: Erlbaum.

Miniscalco Mattsson, C., Mårild, S., \& Pehrsson, N. G. (2001). Evaluation of a languagescreening programme for 2.5-year-olds at Child Health Centres in Sweden. Acta Paediatrica, International Journal of Paediatrics, 90(3), 339-344.

Moein, N., Khoddami, S. M., \& Shahbodaghi, M. R. (2017). A comparison of speech intonation production and perception abilities of Farsi speaking cochlear implanted and normal hearing children. International journal of pediatric otorbinolaryngology, 101, 16. doi:10.1016/j.ijporl.2017.07.018

Moeller, M. P., McCleary, E., Putman, C., Tyler-Krings, A., Hoover, B., \& Stelmachowicz, P. (2010). Longitudinal Development of Phonology and Morphology in Children With Late-Identified Mild-Moderate Sensorineural Hearing Loss. Ear and Hearing, 31(5), 625-635. doi:10.1097/AUD.0b013e3181df5cc2

Moore, B. C. J. (2003). Coding of sounds in the auditory system and its relevance to signal processing and coding in cochlear implants. Otology and Neurotology, 24(2), 243-254. doi:10.1097/00129492-200303000-00019

Moore, B. C. J. (2007). Cochlear hearing loss: Physiological, psychological and technical issues (2nd ed.). Chichester: Wiley.

Morgan, J. L., \& Demuth, K. (1996). Signal to syntax: Bootstrapping from speech to grammar in early acquisition. Mahwah: Erlbaum.

Morton, C. C., \& Nance, W. E. (2006). Current concepts: Newborn hearing screening - A silent revolution. New England Journal of Medicine, 354(20), 2151-2164. doi:10.1056/NEJMra050700

Munson, B., Kurtz, B. A., \& Windsor, J. (2005). The influence of vocabulary size, phonotactic probability, and wordlikeness on nonword repetitions of children with and without specific language impairment. Journal of Speech, Language, and Hearing Research, 48(5), 1033-1047.

Nakata, T., Trehub, S. E., \& Kanda, Y. (2012). Effect of cochlear implants on children's perception and production of speech prosody. The Journal of the Acoustical Society of America, 131(2), 1307-1314. doi:10.1121/1.3672697

Nakeva von Mentzer, C., Lyxell, B., Sahlén, B., Dahlström, Ö., Lindgren, M., Ors, M., . . . Uhlén, I. (2015). Segmental and suprasegmental properties in nonword repetition An explorative study of the associations with nonword decoding in children with normal hearing and children with bilateral cochlear implants. Clinical Linguistics and Phonetics, 29(3), 216-235. doi:10.3109/02699206.2014.987926

Nationalencyklopedin. (2017). Svenska. Retrieved from http://www.ne.se/uppslagsverk/encyklopedi/lång/svenska 
Nespor, M., \& Vogel, I. (1986). Prosodic phonology. Dordrecht: Foris.

Nettelbladt, U. (1983). Developmental studies of dysphonology in children (Vol. 19). Lund: Liber.

Nettelbladt, U. (2007). Fonologisk utveckling. In U. Nettelbladt \& E.-K. Salameh (Eds.), Språkutveckling och språkstörning hos barn (pp. 57-81). Lund, Sweden: Studentlitteratur.

Newbury, D. F., \& Monaco, A. P. (2010). Genetic advances in the study of speech and language disorders. Neuron, 68(2), 309-320. doi:10.1016/j.neuron.2010.10.001

Nicholas, J. G., \& Geers, A. E. (2007). Will they catch up? The role of age at cochlear implantation in the spoken language development of children with severe to profound hearing loss. Journal of Speech, Language, and Hearing Research, 50(4), 10481062. doi:10.1044/1092-4388(2007/073)

Niparko, J. K., Tobey, E. A., Thal, D. J., Eisenberg, L. S., Wang, N. Y., Quittner, A. L., \& Fink, N. E. (2010). Spoken language development in children following cochlear implantation. JAMA - Journal of the American Medical Association, 303(15), 1498-1506. doi:10.1001/jama.2010.451

Nittrouer, S., Caldwell-Tarr, A., Sansom, E., Twersky, J., \& Lowenstein, J. H. (2014). Nonword Repetition in Children With Cochlear Implants: A Potential Clinical Marker of Poor Language Acquisition. American Journal of Speech-Language Pathology, 23(4), 679. doi:10.1044/2014_AJSLP-14-0040

Norbury, C. F., Gooch, D., Wray, C., Baird, G., Charman, T., Simonoff, E., . . Pickles, A. (2016). The impact of nonverbal ability on prevalence and clinical presentation of language disorder: evidence from a population study. Journal of Child Psychology and Psychiatry and Allied Disciplines, 57(11), 1247-1257. doi:10.1111/jcpp.12573

O'Halpin, R. (2010). The perception and production of stress and intonation by children with cocblear implants. University of London, London.

Oberauer, K. (2002). Access to Information in Working Memory: Exploring the Focus of Attention. Journal of Experimental Psychology: Learning Memory and Cognition, 28(3), 411421. doi:10.1037//0278-7393.28.3.411

Offeciers, E., Morera, C., Müller, J., Huarte, A., Shallop, J., \& Cavallé, L. (2005). International consensus on bilateral cochlear implants and bimodal stimulation. Acta Oto-Laryngologica, 125(9), 918-919. doi:10.1080/00016480510044412

Oliver, B., Dale, P. S., \& Plomin, R. (2004). Verbal and nonverbal predictors of early language problems: An analysis of twins in early childhood back to infancy. Journal of Child Language, 31(3), 609-631. doi:10.1017/S0305000904006221

Oller, D. K. (1980). The emergence of the sounds of speech in infancy. In G. YeniKomshian, J. Kavanagh, \& C. A. Ferguson (Eds.), Child phonology: Vol. 1. production (pp. 93-112). New York: Academic Press.

Ota, M. (2006). Children's production of word accents in Swedish revisited. Phonetica, 63(4), 230-246. doi:10.1159/000097307

Peng, S. C., Tomblin, J. B., \& Turner, C. W. (2008). Production and perception of speech intonation in pediatric cochlear implant recipients and individuals with normal hearing. Ear and Hearing, 29(3), 336-351. doi:10.1097/AUD.0b013e318168d94d

Peppé, S. J. E. (2009). Why is prosody in speech-language pathology so difficult. International Journal of Speech-Language Pathology, 11(4), 258-271. doi:10.1080/17549500902906339

Peters, A. M., \& Strömqvist, S. (1996). The role of prosody in the acquisition of grammatical morphemes. In J. L. M. K. Demuth (Ed.), Signal to syntax: Bootstrapping from speech to grammar in early acquisition (pp. 215-232). Hillsdale, US: Lawrence Erlbaum Associates, Inc.

Pettinato, M., De Clerck, I., Verhoeven, J., \& Gillis, S. (2017). Expansion of Prosodic Abilities at the Transition From Babble to Words: A Comparison Between 
Children With Cochlear Implants and Normally Hearing Children. Ear and Hearing, 38(4), 475-486. doi:10.1097/AUD.0000000000000406

Plunkett, K., \& Strömqvist, S. (1992). The Acquisition of Scandinavian Languages. In D. I. Slobin (Ed.), The Crosslinguistic Study of Language Acquisition (Vol. 3, pp. 457-556).

Hillsdale, NJ: Lawrence Erlbaum Associates.

Quittner, A. L., Cruz, I., Barker, D. H., Tobey, E., Eisenberg, L. S., \& Niparko, J. K.

(2013). Effects of maternal sensitivity and cognitive and linguistic stimulation on cochlear implant users' language development over four years. Journal of Pediatrics, 162(2), 343-348.e343. doi:10.1016/j.jpeds.2012.08.003

Raven, J. C., Raven, J. E., \& Court, J. H. (1998). Manual for Raven's progressive matrices and vocabulary scales. San Antonio: Harcourt Assessment.

Reilly, S., Bishop, D. V. M., \& Tomblin, B. (2014). Terminological debate over language impairment in children: Forward movement and sticking points. International Journal of Language and Communication Disorders, 49(4), 452-462. doi:10.1111/14606984.12111

Reilly, S., Wake, M., Ukoumunne, O. C., Bavin, E., Prior, M., Cini, E., . . Bretherton, L. (2010). Predicting language outcomes at 4 years of age: Findings from early language in Victoria study. Pediatrics, 126(6), e1530-e1537. doi:10.1542/peds.20100254

Repovš, G., \& Baddeley, A. (2006). The multi-component model of working memory: Explorations in experimental cognitive psychology. Neuroscience, 139(1), 5-21. doi:10.1016/j.neuroscience.2005.12.061

Riad, T. (2012). Culminativity, stress and tone accent in Central Swedish. Lingua, 122(13), 1352-1379. doi:10.1016/j.lingua.2012.07.001

Riad, T. (2014). The phonology of Swedish. Oxford: Oxford University Press.

Rice, M. L. (2016). Specific Language Impairment, Nonverbal IQ, AttentionDeficit/Hyperactivity Disorder, Autism Spectrum Disorder, Cochlear Implants, Bilingualism, and Dialectal Variants: Defining the Boundaries, Clarifying Clinical Conditions, and Sorting Out Causes. Journal of Speech, Language, and Hearing Research, 59(1), 122-132. doi:10.1044/2015_JSLHR-L-15-0255

Rice, M. L., \& Wexler, K. (1996). Toward tense as a clinical marker of specific language impairment in English-speaking children. Journal of Speech, Language, and Hearing Research, 39(6), 1239-1257.

Rice, M. L., Wexler, K., \& Cleave, P. L. (1995). Specific language impairment as a period of extended optional infinitive. Journal of Speech and Hearing Research, 38(4), 850-863.

Sahlén, B., Reuterskiöld-Wagner, C., Nettelbladt, U., \& Radeborg, K. (1999). Non-word repetition in children with language impairment - Pitfalls and possibilities. International Journal of Language and Communication Disorders, 34(3), 337-352. doi:10.1080/136828299247441

Samuelsson, C., \& Löfqvist, A. (2006). The role of Swedish tonal word accents in children with language impairment. Clinical Linguistics and Phonetics, 20(4), 231-248.

Samuelsson, C., \& Nettelbladt, U. (2004). Prosodic problems in Swedish children with language impairment: Towards a classification of subgroups. International Journal of Language and Communication Disorders, 39(3), 325-344. doi:10.1080/13682820410001654874

Samuelsson, C., Reuterskiöld, C., Nettelbladt, U., \& Sahlén, B. (2011). Production and perception of metrical patterns in Swedish children with language impairment. Logopedics Phoniatrics Vocology, 36(1), 1-11. doi:10.3109/14015439.2010.506195

Samuelsson, C., Scocco, C., \& Nettelbladt, U. (2003). Towards assessment of prosodic abilities in Swedish children with language impairment. Logopedics Phoniatrics Vocology, 28(4), 156-166. doi:10.1080/14015430310018324 
Sander, E. K. (1972). When are speech sounds learned? Journal of Speech and Hearing Disorders, 37(1), 55-63.

SBU. (2004). Allmän böselscreening av nyfödda [Universal Hearing Screening of Newborns]. Retrieved from

Schwartz, R. (2009). Specific language impairment. In R. Schwartz (Ed.), Handbook of child language disorders (pp. 3-43). Hove: Psychology Press.

Segal, O., Houston, D., \& Kishon-Rabin, L. (2016). Auditory Discrimination of Lexical Stress Patterns in Hearing-Impaired Infants with Cochlear Implants Compared with Normal Hearing: Influence of Acoustic Cues and Listening Experience to the Ambient Language. Ear and Hearing, 37(2), 225-234. doi:10.1097/AUD.0000000000000243

Selkirk, E. O. (1986). Phonology and syntax: The relationship between sound and structure. Cambridge, MA: MIT press.

Sharma, A., Nash, A. A., \& Dorman, M. F. (2009). Cortical development, plasticity and reorganization in children with cochlear implants. Journal of Communication Disorders, 42(4), 272-279. doi:https://doi.org/10.1016/j.jcomdis.2009.03.003

Shriberg, L. D., Austin, D., Lewis, B. A., McSweeny, J. L., \& Wilson, D. L. (1997). The percentage of consonants correct (PCC)metric: Extensions and reliability data. Journal of Speech, Language, and Hearing Research, 40(4), 708-722.

Shriberg, L. D., \& Kwiatkowski, J. (1982). Phonological disorders. III: A procedure for assessing severity of involvement. Journal of Speech and Hearing Disorders, 47(3), 256270.

Skarzynski, H., Lorens, A., Piotrowska, A., \& Anderson, I. (2007). Preservation of low frequency hearing in partial deafness cochlear implantation (PDCI) using the round window surgical approach. Acta Oto-Laryngologica, 127(1), 41-48. doi:10.1080/00016480500488917

Smith, R. J. H., Bale Jr, J. F., \& White, K. R. (2005). Sensorineural hearing loss in children. Lancet, 365(9462), 879-890. doi:10.1016/S0140-6736(05)71047-3

Snow, D. (2015). List intonation in pre-schoolers with normal and disordered language development. Clinical Linguistics and Phonetics, 29(11), 852-872. doi:10.3109/02699206.2015.1059892

Snowling, M., Chiat, S., \& Hulme, C. (1991). Words, nonwords, and phonological processes: Some comments on Gathercole, Willis, Emslie, and Baddeley. Applied Psycholinguistics, 12(3), 369-373. doi:10.1017/S0142716400009279

Socialstyrelsen. (2009). Behandling av barn med cochleaimplantat som rikssjukvaird (2009-130-4). Retrieved from

Spaulding, T. J., Plante, E., \& Farinella, K. A. (2006). Eligibility criteria for language impairment: Is the low end of normal always appropriate? Language, Speech, and Hearing Services in Schools, 37(1), 61-72. doi:10.1044/0161-1461(2006/007)

Speer, S. R., \& Ito, K. (2009). Prosody in first language acquisition - Acquiring intonation as a tool to organize information in conversation. Linguistics and Language Compass, 3(1), 90-110. doi:10.1111/j.1749-818X.2008.00103.x

Spencer, L. J., \& Guo, L.-Y. (2013). Consonant Development in Pediatric Cochlear Implant Users Who Were Implanted Before 30 Months of Age. The Journal of Deaf Studies and Deaf Education, 18(1), 93-109. doi:10.1093/deafed/ens038

Stephens, D. (2001). Audiological terms. In A. Martini, M. Mazzoli, A. Read, \& D. Stephens (Eds.), Definitions, protocols and guidelines in genetic hearing impairment (pp. 914). London: Whurr Publishers.

Stika, C. J., Eisenberg, L. S., Johnson, K. C., Henning, S. C., Colson, B. G., Ganguly, D. H., \& DesJardin, J. L. (2015). Developmental outcomes of early-identified children 
who are hard of hearing at 12 to 18 months of age. Early Human Development, 91(1), 47-55. doi:10.1016/j.earlhumdev.2014.11.005

Storkel, H. L., \& Hoover, J. R. (2010). An online calculator to compute phonotactic probability and neighborhood density on the basis of child corpora of spoken American English. Behavior Research Methods, 42(2), 497-506. doi:10.3758/BRM.42.2.497

Stothard, S. E., Snowling, M. J., Bishop, D. V. M., Chipchase, B. B., \& Kaplan, C. A. (1998). Language-impaired preschoolers: A follow-up into adolescence. Journal of Speech, Language, and Hearing Research, 41(2), 407-418.

Sullivan, J. (2013). Little ears and brains: Hearing aids and intervention. Seminars in Hearing, 34(4), 288-297. doi:10.1055/s-0033-1356641

Svirsky, M. A., Stallings, L. M., Lento, C. L., Ying, E., \& Leonard, L. B. (2002). Grammatical morphologic development in pediatric cochlear implant users may be affected by the perceptual prominence of the relevant markers. Annals of Otology, Rhinology and Laryngology, 111(5 II), 109-112.

Szagun, G., \& Stumper, B. (2012). Age or experience? The influence of age at implantation and social and linguistic environment on language development in children with cochlear implants. Journal of Speech, Language, and Hearing Research, 55(6), 1640-1654. doi:10.1044/1092-4388(2012/11-0119)

Tallal, P., Miller, S. L., Bedi, G., Byma, G., Wang, X., Nagarajan, S. S., . . Merzenich, M. M. (1996). Language comprehension in language-learning impaired children improved with acoustically modified speech. Science, 271(5245), 81-84.

Tallal, P., \& Piercy, M. (1973a). Defects of non-verbal auditory perception in children with developmental aphasia [20]. Nature, 241(5390), 468-469. doi:10.1038/241468a0

Tallal, P., \& Piercy, M. (1973b). Developmental aphasia: impaired rate of non-verbal processing as a function of sensory modality. Neuropsychologia, 11(4), 389-398. doi:10.1016/0028-3932(73)90025-0

Tallal, P., \& Piercy, M. (1974). Developmental aphasia: Rate of auditory processing and selective impairment of consonant perception. Neuropsychologia, 12(1), 83-93. doi:10.1016/0028-3932(74)90030-X

Titterington, J., Henry, A., Krämer, M., Toner, J. G., \& Stevenson, M. (2006). An investigation of weak syllable processing in deaf children with cochlear implants. Clinical Linguistics and Phonetics, 20(4), 249-269. doi:10.1080/02699200400015291

Tomblin, J. B., Records, N. L., Buckwalter, P., Zhang, X., Smith, E., \& O'Brien, M. (1997). Prevalence of specific language impairment in kindergarten children. Journal of Speech, Language \& Hearing Research, 40(6), 1245.

Torppa, R., Faulkner, A., Huotilainen, M., Järvikivi, J., Lipsanen, J., Laasonen, M., \& Vainio, M. (2014). The perception of prosody and associated auditory cues in earlyimplanted children: The role of auditory working memory and musical activities. International Journal of Audiology, 53(3), 182-191. doi:10.3109/14992027.2013.872302

Trevarthen, C., \& Aitken, K. J. (2001). Infant intersubjectivity: Research, theory, and clinical applications. Journal of Child Psychology and Psychiatry and Allied Disciplines, 42(1), 3-48. doi:10.1017/S0021963001006552

Ullman, M. T., \& Pierpont, E. I. (2005). Specific language impairment is not specific to language: The procedural deficit hypothesis. Cortex, 41(3), 399-433. doi:10.1016/S0010-9452(08)70276-4

Wake, M., Tobin, S., Cone-Wesson, B., Dahl, H. H., Gillam, L., McCormick, L., . . . Williams, J. (2006). Slight/mild sensorineural hearing loss in children. Pediatrics, 118(5), 1842-1851. doi:10.1542/peds.2005-3168

Vallar, G., \& Baddeley, A. (1987). Phonological Short-term Store and Sentence Processing. Cognitive Neuropsychology, 4(4), 417-438. doi:10.1080/02643298708252046 
Vallar, G., \& Papagno, C. (2002). Neuropsychological impairments of verbal short-term memory. In A. Baddeley, M. D. Kopelman, \& B. A. Wilson (Eds.), The handbook of memory disorders (2nd ed.). Chichester: Wiley.

van der Lely, H. K. J. (2005). Domain-specific cognitive systems: Insight from Grammatical-SLI. Trends in cognitive sciences, 9(2), 53-59. doi:10.1016/j.tics.2004.12.002

Wass, M. (2009). Children with cochlear implants: Cognition and reading ability. Linköping University Electronic Press, Linköping.

Wechsler, D. (2005). Wechsler Preschool and Primary Scale of Intelligence. Swedish version. (3 ed.). Stockholm, Sweden: Psykologiförlaget AB.

Wells, B., \& Peppé, S. (2003). Intonation abilities of children with speech and language impairments. Journal of Speech, Language, and Hearing Research, 46(1), 5-20. doi:10.1044/1092-4388(2003/001)

Wells, B., Peppé, S., \& Goulandris, N. (2004). Intonation development from five to thirteen. Journal of Child Language, 31(4), 749-778. doi:10.1017/S030500090400652X

Velupillai, V. (2012). An introduction to linguistic typology. Philadelphia: John Benjamins Publishing Company.

Westerlund, M. (1994). Barn med tal- och språkavvikelser. En prospektiv longitudinell epidemiologisk studie av en årskull Uppsalabarn vid 4, 7 och 9 års ålder [Children with deviant speech and language. A prospective, longitudinal epidemiological study of an age group of children in Uppsala at age 4, 7 and 9 years]. Stockholm: Almqvist \& Wiksell International.

White, K. R., Forsman, I., Eichwald, J., \& Munoz, K. (2010). The Evolution of Early Hearing Detection and Intervention Programs in the United States. Seminars in Perinatology, 34(2), 170-179. doi:10.1053/j.semperi.2009.12.009

Vihman, M. M. (2013). Phonological Development: The First Two Years. Somerset, United States: Wiley.

Vihman, M. M., DePaolis, R. A., \& Davis, B. L. (1998). Is There a "Trochaic Bias" in Early Word Learning? Evidence from Infant Production in English and French. Child development, 69(4), 935-949.

Wilson, A. C., \& Bishop, D. V. M. (2018). Resounding failure to replicate links between developmental language disorder and cerebral lateralisation. Peerj, 2018(1). doi: 10.7717 /peerj. 4217

World Health Organization. (1993). The ICD-10 classification of mental and behavioural disorders: diagnostic criteria for research (Vol. 2). Geneva: World Health Organization.

World Health Organization. (2001). International Classification of Functioning, Disability and Health: ICF: World Health Organization.

World Health Organization. (2002). Towards a common language for functioning, disability and bealth. Geneva, Switzerland: World Health Organization.

World Health Organization. (2010). International statistical classification of diseases and related health problems, 10th revision, 2010 Edition (2010 ed.). Geneva, Switzerland: World Health Organization.

World Health Organization. (2018a). Grades of hearing impairment. Retrieved from http://www.who.int/pbd/deafness/hearing_impairment_grades/en/

World Health Organization. (2018b). ICD-11 Beta Draft. Retrieved from https://icd.who.int/dev11/

Yew, S. G. K., \& O'Kearney, R. (2013). Emotional and behavioural outcomes later in childhood and adolescence for children with specific language impairments: Metaanalyses of controlled prospective studies. Journal of Child Psychology and Psychiatry and Allied Disciplines, 54(5), 516-524. doi:10.1111/jcpp.12009 
Yoshinaga-Itano, C. (2014). Principles and guidelines for early intervention after confirmation that a child is deaf or hard of hearing. Journal of Deaf Studies and Deaf Education, 19(2), 143-175. doi:10.1093/deafed/ent043

Zora, H., Riad, T., Schwarz, I. C., \& Heldner, M. (2016). Lexical specification of prosodic information in Swedish: Evidence from mismatch negativity. Frontiers in Neuroscience, 10(NOV). doi:10.3389/fnins.2016.00533

Zwolan, T. A. (2009). Cochlear implants. In J. Katz, L. Medwetsky, R. F. Burkard, \& L. J. Hood (Eds.), Handbook of clinical audiology (6th ed., pp. 912-933). Philadelphia: Lippincott Williams \& Wilkins.

Figure 1. Cochlear implant device. Used with permission from Cochlear.

Figure 2. Reprinted from Neuroscience, Volume 139, Issue 1, Repovš, G. \&

Baddeley, A., page 6, (C) 2006, with permission from Elsevier. 


\section{Papers}

The papers associated with this thesis have been removed for copyright reasons. For more details about these see:

http://urn.kb.se/resolve?urn=urn:nbn:se:liu:diva-147836 


\section{Studies from the Swedish Institute for Disability Research}

1. Varieties of reading disability

Stefan Gustafson

ISBN 91-7219-867-2, 2000

2. Cognitive functions in drivers with brain injury - anticipation and adaptation Anna Lundqvist

ISBN 91-7219-967-9, 2001

3. Cognitive deafness

Ulf Andersson

ISBN 91-7373-029-7, 2001

4. Att lära sig leva med förvärvad hörselnedsättning sett ur par-perspektiv

Carin Fredriksson

ISBN 91-7373-105-6, 2001

5. Signs, Symptoms, and Disability Related to the Musculo-Skeletal System Gunnar Lundberg

ISBN 91-7373-160-9, 2002

6. Participation - Ideology and Everyday Life

Anette Kjellberg

ISBN 91-7373-371-7, 2002

7. Föräldrar med funktionshinder - om barn, föräldraskap och familjeliv

Marie Gustavsson Holmström

ISBN 91-7203-500-5, 2002

8. Active wheelchair use in daily life

Kersti Samuelsson

ISBN 91-7373-196-X, 2002

9. Två kön eller inget alls. Politiska intentioner och vardagslivets realiteter i den arbetslivsinriktade rehabiliteringen

Marie Jansson

ISBN 91-7373-568-X, 2003 
10. Audiological and cognitive long-term sequelae from closed head injury Per-Olof Bergemalm

ISBN 91-7668-384-2, 2004

11. Att vara i särklass - om delaktighet och utanförskap i gymnasiesärskolan Martin Molin

ISBN 91-85295-46-9, 2004

12. Rättvis idrottsundervisning för elever med rörelsehinder - dilemma kring omfördelning och erkännande

Kajsa Jerlinder

Licentiate Degree, 2005

13. Hearing impairment and deafness. Genetic and environmental factors interactions - consequences. A clinical audiological approach

Per-Inge Carlsson

ISBN 91-7668-426-1, 2005

14. Hearing and cognition in speech comprehension. Methods and applications Mathias Hällgren

ISBN 91-85297-93-3, 2005

15. Living with deteriorating and hereditary disease: experiences over ten years of persons with muscular dystrophy and their next of kin

Katrin Boström

ISBN 91-7668-427-x, 2005

16. Disease and disability in early rheumatoid arthritis

Ingrid Thyberg

ISBN 91-85299-16-2, 2005

17. "Varför får jag icke följa med dit fram?" Medborgarskapet och den offentliga debatten om dövstumma och blinda 1860-1914

Staffan Bengtsson

ISBN 91-85457-06-X, 2005

18. Modalities of Mind. Modality-specific and nonmodality-specific aspects of working memory for sign and speech

Mary Rudner

ISBN 91-85457-10-8, 2005 
19. Facing the Illusion Piece by Piece. Face recognition for persons with learning disability

Henrik Danielsson

ISBN 91-85497-09-6, 2006

20. Vuxna med förvärvad traumatisk hjärnskada - omställningsprocesser och konsekvenser i vardagslivet. En studie av femton personers upplevelser och erfarenheter av att leva med förvärvad traumatisk hjärnskada

Thomas Strandberg

ISBN 91-7668-498-9, 2006

21. Nycklar till kommunikation. Kommunikation mellan vuxna personer med grav förvärvad hjärnskada och personernas närstående, anhöriga och personal

Pia Käcker

ISBN 978-91-85715-88-6, 2007

22. ”Aspergern, det är jag”. En intervjustudie om att leva med Asperger syndrom

Gunvor Larsson Abbad

ISBN 978-91-85831-43-2, 2007

23. Sounds of silence - Phonological awareness and written language in children with and without speech

Janna Ferreira

ISBN 978-91-85895-74-8, 2007

24. Postponed Plans: Prospective Memory and Intellectual Disability

Anna Levén

ISBN 978-91-85895-57-1, 2007

25. Consequences of brain tumours from the perspective of the patients and of their next of kin

Tanja Edvardsson

ISBN 978-91-7668-572-3, 2008

26. Impact on participation and service for persons with deafblindness

Kerstin Möller

ISBN 978-91-7668-595-2, 2008

27. Approaches to Audiological Rehabilitation with Hearing Aids: studies on prefitting strategies and assessment of outcomes

Marie Öberg

ISBN 978-91-7393-828-0, 2008 
28. Social Interaction and Participation in Activities of Everyday Life Among Persons with Schizophrenia

Maria Yilmaz

Licentiate Degree, 2009

29. Focus on Chronic Disease through Different Lenses of Expertise

Towards Implementation of Patient-Focused

Decision Support Preventing Disability:

The example of Early Rheumatoid Arthritis

Örjan Dahlström

ISBN 978-91-7393-613-2, 2009

30. Children with Cochlear Implants: Cognition and Reading Ability

Malin Wass

ISBN: 978-91-7393-487-9, 2009

31. Restricted participation:

Unaccompanied children in interpreter-mediated asylum hearings in Sweden

Olga Keselman

ISBN: 978-91-7393-499-2, 2009

32. Deaf people and labour market in Sweden.

Education - Employment - Economy

Emelie Rydberg

ISBN: 978-91-7668-725-3, 2010

33. Social rättvisa i inkluderande idrottsundervisning

för elever med rörelsehinder - en utopi?

Kajsa Jerlinder

ISBN: 978-91-7668-726-0, 2010

34. Erfarenheter av rehabiliteringsprocessen mot ett arbetsliv

- brukarens och de professionellas perspektiv

Helene Hillborg

ISBN: 978-91-7668-741-3, 2010

35. Knowing me, knowing you - Mentalization abilities of children who use augmentative and alternative communication

Annette Sundqvist

ISBN: 978-91-7393-316-2, 2010 
36. Lärare, socialsekreterare och barn som far illa - om sociala representationer och interprofessionell samverkan

Per Germundsson

ISBN: 978-91-7668-787-1, 2011

37. Fats in Mind

Effects of Omega-3 Fatty Acids on Cognition and Behaviour in Childhood

Ulrika Birberg Thornberg

ISBN: 978-91-7393-164-9, 2011

38. ”Jobbet är kommunikation”

Om användning av arbetshjälpmedel för personer med hörselnedsättning

Sif Bjarnason

Licentiate Degree. ISBN: 978-91-7668-835-9, 2011

39. Applying the ICF-CY to identify everyday life situations of children and youth with disabilities

Margareta Adolfsson

ISBN: 978-91-628-8342-3, 2011

40. Tinnitus - an acceptance-based approach

Vendela Zetterqvist

ISBN: 978-91-7393-040-6, 2011

41. Applicability of the ICF-CY to describe functioning and environment of children with disabilities

Nina Klang

ISBN: 978-91-7668-864-9, 2012

42. Bringing more to participation

Participation in school activities of persons with Disability within the framework of the International Classification of Functioning, Disability and Health for Children and Youth (ICF-CY)

Gregor Maxwell

ISBN: 978-91-628-8484-0, 2012

43. From Eye to Us.

Prerequisites for and levels of participation in mainstream school of persons with Autism Spectrum Conditions

Marita Falkmer

ISBN: 978-91-637-2091-8, 2013 
44. Otosclerosis, clinical long-term perspectives

Ylva Dahlin-Redfors

ISBN 978-91-628-8617-2, 2013

45. Tinnitus in Context - A Contemporary Contextual Behavioral Approach Hugo Hesser

ISBN 978-91-7519-701-2, 2013

46. Hearing and middle ear status in children and young adults with cleft palate Traci Flynn

ISBN 978-91-628-8645-5, 2013

47. Utrymme för deltagande, beslutsprocesser $\mathbf{i}$ möten mellan patienter med ospecifika ländryggsbesvär och sjukgymnaster i primär vård

Iréne Josephson

ISBN 42-978-91-85835-41-6, 2013

48. Man vill ju klara sig själv” Studievardagen för studenter med Asperger syndrom i högre studier

Ann Simmeborn Fleischer

ISBN 978-91-628-8681-3, 2013

49. Cognitive erosion and its implications in Alzheimer's disease

Selina Mårdh

ISBN 978-91-7519-621-1, 2013

50. Hörselscreening av en population med utvecklingsstörning

Utvärdering av psykoakustisk testmetod och av OAE-registrering som komplementär metod

Eva Andersson

Licentiate Degree. ISBN 978-91-7519-616-9, 2013

51. Skolformens komplexitet - elevers erfarenheter av skolvardag och tillhörighet i gymnasiesärskolan

Therése Mineur

ISBN 978-91-7668-951-6, 2013

52. Evaluating the process of change:

Studies on patient journey, hearing disability acceptance and stages-of-change

Vinaya Kumar Channapatna Manchaiah

ISBN 978-91-7519-534-6, 2013 
53. Cognition in hearing aid users: Memory for everyday speech

Hoi Ning (Elaine) $\mathrm{Ng}$

ISBN 978-91-7519-494-3, 2013

54. Representing sounds and spellings Phonological decline and compensatory working memory in acquired hearing impairment

Elisabet Classon

ISBN 978-91-7519-500-1, 2013

55. Assessment of participation in people with a mild intellectual disability

Patrik Arvidsson

ISBN 978-91-7668-974-5, 2013

56. Barnperspektiv i barnavårdsutredningar - med barns hälsa och barns upplevelser i fokus

Elin Hultman

ISBN 978-91-7519-457-8, 2013

57. Internet Interventions for Hearing Loss

Examining rehabilitation Self-report measures and Internet use in hearing-aid users

Elisabet Sundewall Thorén

ISBN 978-91-7519-423-3, 2014

58. Exploring Cognitive Spare Capacity: Executive Processing of Degraded Speech Sushmit Mishra

ISBN 978-91-7519-386-1, 2014

59. Supported employment i en svensk kontext - förutsättningar när personer med funktionsnedsättning når, får och behåller ett arbete

Johanna Gustafsson

ISBN 978-91-7529-012-6, 2014

60. Effects of Specific Cochlear Pathologies on the Auditory Functions:

Modelling, Simulations and Clinical Implications

Amin Saremi

ISBN 978-91-7519-365-6, 2014 
61. Children with profound intellectual and multiple disabilities and their participation in family activities

Anna Karin Axelsson

ISBN 978-91-85835-48-5, 2014

62. Lexical and Semantic Development in Children With Cochlear Implants

Ulrika Löfkvist

ISBN 978-91-7549-546-0, 2014

63. Rethinking sound. Computer-assisted reading intervention with a phonics approach for deaf and hard of hearing children using cochlear implants or hearing aids

Cecilia Nakeva von Mentzer

ISBN 978-91-7519-270-3, 2014

64. Assessing cognitive spare capacity as a measure of listening effort using the Auditory Inference Span Test

Niklas Rönnberg

ISBN 978-91-7519-267-3, 2014

65. Employees with Aided Hearing Impairment: An Interdisciplinary Perspective

Håkan Hua

ISBN 978-91-7519-240-6, 2014

66. Prosthetic and Orthotic Services in Developing Countries

Lina Magnusson

ISBN 978-91-85835-55-3, 2014

67. Dealing with digits - Arithmetic, memory and phonology in deaf signers Josefine Andin

ISBN: 978-91-7519-235-2, 2014

68. Time is of the essence in speech recognition: Get it fast or think about it Shahram Moradi

ISBN: 978-91-7519-188-1, 2014

69. Effects of hearing loss on traffic safety and mobility

Birgitta Thorslund

ISBN: 978-91-7519-178-2, 2014 
70. Aspekter på lärande vid dövblindhet - möjligheter och begränsningar för personer med Alström syndrom

Berit Rönnåsen

Licentiate Degree. ISBN: 978-91-7529-068-3, 2015

71. Memory and communication in typically developing infants and children with Autism Spectrum Disorder: Behavioral and electrophysiological indices

Emelie Nordqvist

ISBN: 978-91-7519-078-5, 2015

72. Cognitive capacities and composite cognitive skills in individuals with

Usher syndrome type 1 and 2

Cecilia Henricson

ISBN: 978-91-7685-999-5, 2015

73. Functioning and Disability in Adults with Hearing Loss

Preparatory studies in the ICF Core Sets for Hearing Loss project

Sarah Granberg

ISBN: 978-91-7529-086-7, 2015

74. Speech recognition and memory processes in native and non-native language perception

Lisa Kilman

ISBN: 978-91-7685-972-8, 2015

75. To include or not to include: Teachers' social representations of inclusion of students with Asperger diagnosis

Ann-Charlotte Linton

ISBN: 978-91-7685-956-8, 2015

76. Health and People with Usher syndrome

Moa Wahlqvist

ISBN: 978-91-7529-098-0, 2015

77. Children with mild intellectual disability and their families - needs for support, service utilisation and experiences of support

Lena Olsson

ISBN: 978-91-85835-66-9, 2016 
78. Deafblindness

Theory-of-mind, cognitive functioning and social network in Alström syndrome

Hans-Erik Frölander

ISBN: 978-91-7529-132-1, 2016

79. Signs for Developing Reading

Sign Language and Reading Development in Deaf and Hard-of-Hearing Children

Emil Holmer

ISBN: 978-91-7685-767-0, 2016

80. Speech masking speech in everyday communication

The role of inhibitory control and working memory capacity

Victoria Stenbäck

ISBN: 978-7685-604-8, 2017

81. Neural and Cognitive Effects of Hearing Loss on Speech Processing

Eline Borch Petersen

ISBN: 978-91-7685-640-6, 2017

82. A biopsychosocial approach to functioning, oral health and specialist dental health care in children with disabilities - Swedish and international perspectives

Johanna Norderyd

ISBN: 978-91-85835-81-2, 2017

83. Samverkansprojekt, och sen då? - en uppföljande studie av samverkansprocessen kring barn och unga som far illa eller riskerar att fara illa

Ulrika Englund

ISBN: 978-91-7529-194-9, 2017

84. Aural rehabilitation programs for hearing aid users

Evaluating and clinically applying educational programs, supported via telephone and/or the internet and professionally guided by an audiologist

Milijana Malmberg

ISBN: 978-91-629-0187-5, 2017

85. Tolkning vid förmedlade samtal via Bildtelefoni.net

- interaktion och gemensamt meningsskapande

Camilla Warnicke

ISBN: 978-91-7529-197-0, 2017 
86. Vardagslivets aktiviteter. Handlingen som terapeutiskt redskap för personer med svårare psykiska funktionshinder - Analys av arbetsterapeuters berättelser med utgångspunkt i G H Meads teori om social handling

Marianne Boström

ISBN: 978-91-7529-206-9, 2017

87. Creative disability classification systems: The case of Greece, 1990-2015

Antonia Pavli

ISBN: 978-91-7529-204-5, 2017

88. Ej utgiven

89. Perception of disturbing sounds

Investigations of people with hearing loss and normal hearing

Åsa Skagerstrand

ISBN: 978-91-7529-229-8, 2018

90. Peer Interaction in Preschool: Necessary, but not Sufficient The Influence of Social Interaction on the Link between Behaviour Difficulties and Engagement among Children with and without Need of Special Support Madeleine Sjöman

ISBN: 978-91-88339-13-3, 2018 